\title{
Central hypotheses for the third agroforestry paradigm within a common definition
}

Meine van Noordwijk, Ric Coe, Fergus Sinclair

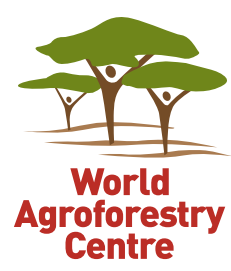





\section{Central hypotheses for the third agroforestry paradigm within a common definition}

Meine van Noordwijk, Ric Coe, Fergus Sinclair 


\section{LIMITED CIRCULATION}

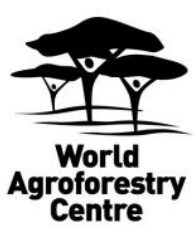

Correct citation:

van Noordwijk M, Coe R, Sinclair F. 2016. Central hypotheses for the third agroforestry paradigm within a common definition. Working paper 233, Bogor, Indonesia: World Agroforestry Centre (ICRAF) Southeast Asia Regional Program. DOI: http://dx.doi.org/10.5716/WP16079.PDF

Corresponding author: m.vannoordwijk@ cgiar.org

Titles in the Working Paper series aim to disseminate interim results on agroforestry research and practices, and stimulate feedback from the scientific community. Other publication series from the World Agroforestry Centre include: Technical Manuals, Occasional Papers and the Trees for Change Series.

Published by the World Agroforestry Centre

United Nations Avenue

PO Box 30677, GPO 00100

Nairobi, Kenya

Tel: +254 207224000 , via USA +1 6508336645

Email: worldagroforestry@cgiar.org

Website: www.worlagroforestry.org

(C) World Agroforestry Centre 2016

Working Paper No. 233

Photos/illustrations:

The views expressed in this publication are those of the author(s) and not necessarily those of the World Agroforestry Centre.

Articles appearing in this publication may be quoted or reproduced without charge, provided the source is acknowledged.

All images remain the sole property of their source and may not be used for any purpose without written permission from the source. 


\section{Table of contents}

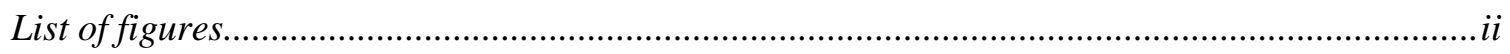

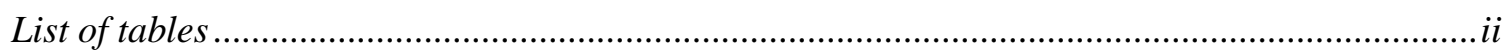

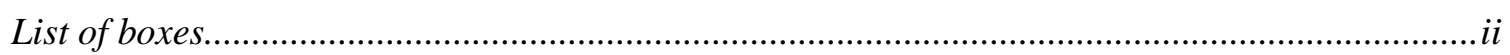

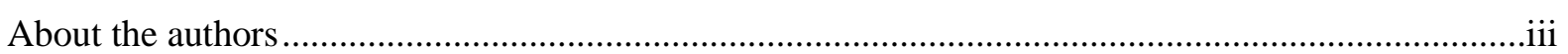

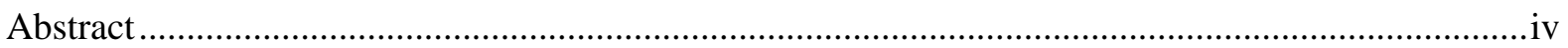

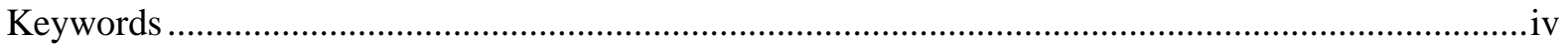

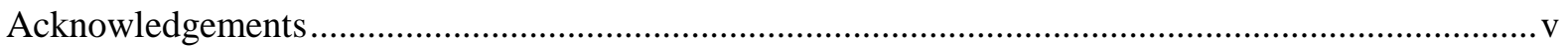

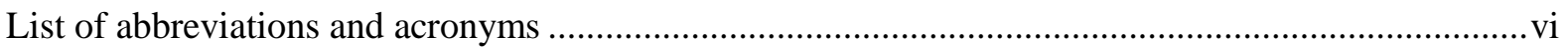

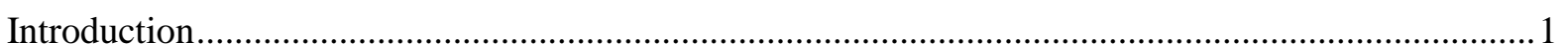

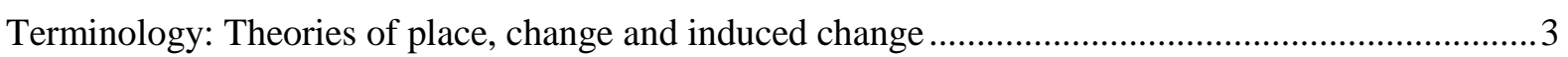

Definitions, concepts and hypotheses of the first agroforestry paradigm ........................................... 4

Definitions, concepts and hypotheses of the second agroforestry paradigm ........................................ 9

Emergence of a third, policy-oriented agroforestry paradigm ............................................................. 14

Proposed new definition ......................................................................................................... 19

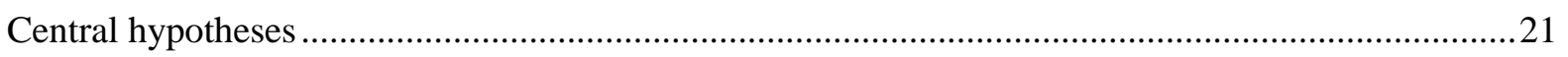

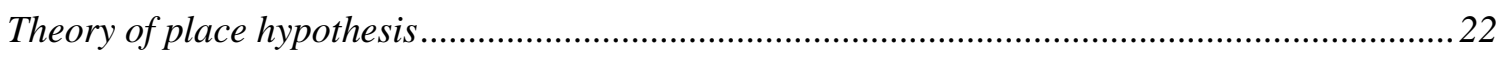

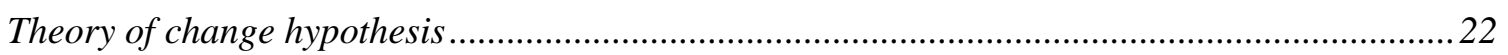

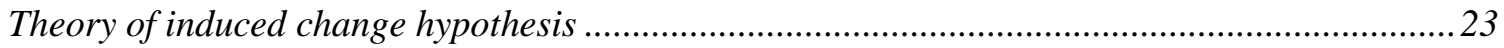

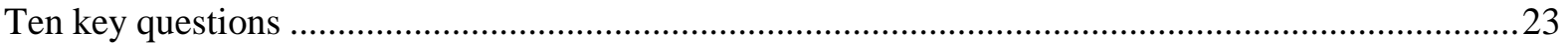

Discussion: Conceptual diversity and institutional sustainagility ....................................................24

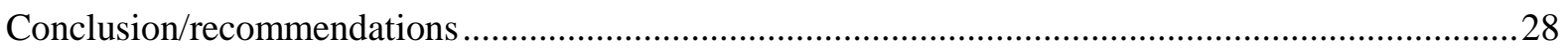

Appendix. FTA Phase II plans as communicated through 28 Hypotheses, 15 Assumptions and

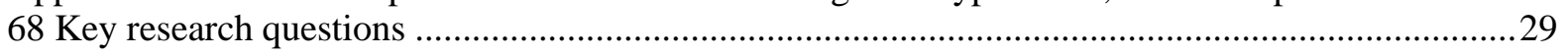

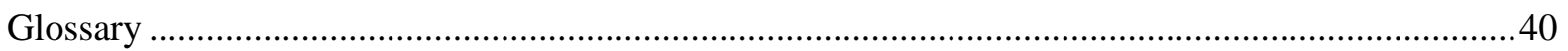

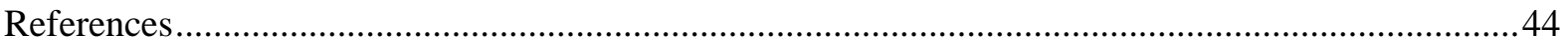




\section{List of figures}

Figure 1. Three interacting domains of knowledge and praxis that need to be joined up to achieve the societal benefits agroforestry can potentially provide...

Figure 2. Representation of multi-phase "diagnose and design" (D\&D) learning loops and project cycles thirty five years ago (ICRAF 1982)

Figure 3. Aspects of belowground interactions reviewed as part of the overarching agroforestry hypothesis focused on resource capture and dynamics (van Noordwijk et al 2004a)

Figure 4. Example of the learning curve and continuous refinement of "Theories of Change" (ToC) in a long-term partnership program for tropical forest margins, gradually building up its Theory of Induced Change (Minang et al 2014a)

Figure 5. Representations of agroforestry as the central part of a land use triangle, (a) developed by the authors of this working paper, (b) AGFORWARD project is promoting agroforestry practices i.e. the integration of trees with farming. Agroforestry comprises the integration of trees (and shrubs) with crop and/or livestock systems http://www.agforward.eu/index.php/en/ den Herder et al 2015.

Figure 6. Three agroforestry concepts of increasing complexity and degree of nesting

Figure 7. Three agroforestry concepts mapped on to the agriculture-forestry interface (van Noordwijk 2014).

Figure 8. Modern version of the multiple learning loops of Figure 2 as a continuous cycle that links knowledge with action across scales, on the basis of six essential skills... 19

\section{List of tables}

Table 1. Articulations of the basic agroforestry definition at multiple scales, and the contrasts with non-agroforestry it suggests to be open for empirical research (* see glossary)

\section{List of boxes}

Box 1. First ICRAF articulation of concepts and purpose of agroforestry research.

Box 2. Some highlights of agroforestry research and development at ICRAF in the first agroforestry paradigm ${ }^{1}$....

Box 3. Some highlights of agroforestry research and development at ICRAF in the third agroforestry paradigm.

Box 4. Some highlights of agroforestry research and development at ICRAF in the fourt agroforestry paradigm.

Box 5. Credibility, Salience and Legitimacy as hallmarks of usable knowledge 


\section{About the authors}

Meine van Noordwijk serves as Chief Scientist at the World Agroforestry Centre (ICRAF) and is based in Bogor (Indonesia). He is also part-time Professor of Agroforestry at Wageningen University (the Netherlands). Trained as biologist/ ecologist he has experience with systems analysis and modelling of systems that range from single roots in soil, via tree-soil-crop interactions, to the understanding of water, biodiversity and greenhouse gasses at landscapes scales, and the conflicts that arise over multiple claims to landscape functions to the institutional translation of ecosystem service concepts in a comprehensive approach to land use systems.

Ric Coe is a Principal Scientist and research methods specialist at the World Agroforestry Centre (ICRAF), Kenya and also at the Statistics for Sustainable Development, UK. He helps teams engaged in agricultural and environmental research improve research quality and effectiveness through application of statistical principles during conception, design, analysis and interpretation of projects and studies. He has been doing this for quite a long time.

Fergus Sinclair is Leader of the Systems Science Domain at the World Agroforestry Centre (ICRAF) based in Nairobi, Kenya through a collaborative arrangement with Bangor University, Wales, UK where is on the faculty in the School of the Environment, Natural Resources and Geography. He is also an Honorary Professor at CATIE (Centre for Agricultural Research and Higher Education), Costa Rica and an Honorary Editor of the journal Agroforestry Systems. He is best known for his pioneering research on systematic acquisition and use of local knowledge and the development and application of systems methods in agricultural development, including measurement and modelling of complex systems at field, farm, livelihood and landscape scales, encompassing both ecological and human dimensions. 


\section{Abstract}

In the four decades of its existence, agroforestry as a concept has been understood and defined in multiple ways, often referring to a specific system scale of interest. This has ranged from trees, via tree-soil-crop interactions at plot level to the interactions between land, labour, knowledge and investment at farm level. These in turn shape human livelihoods at landscape scale, dynamics of tree cover change in space and time, socio-ecological systems at landscape scale, the multiple value chains that start with tree, crop and livestock production in landscapes, and the policy domains of forestry and agriculture in the context of sustainable development goals, globalizing markets and global climate change. We propose a new, simple definition': "Agroforestry, a contraction of the terms agriculture and forestry, is land use that combines aspects of both, including the agricultural use of trees." This includes trees on farms and in agricultural landscapes, farming in forests and at forest margins and tree-crop production, including cocoa, coffee, rubber and oilpalm. It includes interactions between agriculture and forestry as policy domains. Interactions between trees and other components of agriculture may be important at a range of scales: in fields (where trees and crops are grown together), on farms (where trees may provide fodder for livestock, fuel, food, shelter or income from products including timber) and landscapes (where agricultural and forest land uses combine in determining the provision of ecosystem services). At national and global scales, forestry and agriculture interact ecologically and through policies relating to land use and trade and are important with respect to climate change and other environmental concerns. Agroforestry embraces an agroecological approach emphasising multifunctionality and the management of complex systems and polycultures rather than focusing exclusively on monoculture. At each scale we need clarity on what non-agroforestry comparisons can be made, before any hypotheses on properties of agroforestry can be tested. We discuss current use of agroforestry in terms of "theory of place", describing context, "theory of change", understanding options and choices, and "theory of induced change", articulating how interventions can be evaluated a priori on likely effectiveness, in socio-ecological systems with multiple feedbacks. Effectiveness and tradeoffs are to be evaluated across the full set of sustainable development goals. One overarching hypothesis for each of these three theory domains is proposed, with an indication of the type of evidence that could lead to rejection or at least refinement of the statement. Answers to a coherent set of ten questions can increase the system level understanding of emerging issues, available and new options, and ways to evaluate scenarios and form platforms for change, all in local context. As umbrella term for bringing agriculture and forestry aspects together, agroforestry has an ambitious but important role in current debates.

\section{Keywords}

agriculture, forest definition, sustainable development goals, nested scales, boundary work

\footnotetext{
${ }^{1}$ Other options are: A) "Agroforestry is the combination of agriculture and forestry, including..." or B)

"Agroforestry is the combination of agriculture and trees, including..."
} 


\section{Acknowledgements}

The substance of this working paper owes to discussions over the years with many colleagues inside and outside of ICRAF. Many contributed through discussions at the ICRAF Science Week 2016 in Nairobi (5-10 September). Beyond many nameless particiapnats of ICRAF Science Week in 2016, these include Eduardo Somariba (CATIE), Christian Dupraz (INRA), Emmanuel Torquebiau (CIRAD), Hubert de Foresta (IRD), Tom Tomich (U of Davis), Ken Giller and Frans Bongers (Wageningen University) and ICRAF colleagues Ramni Jamnadas, Peter Minang, Ravi Prabhu, Dennis P Garrity, Sonya Dewi, Jianchu Xu, Valentina Robiglio, Betha Lusiana, Beria Leimona, Delia Catacutan, Robert J Zomer, Lalisa Duguma, Ingrid Oborn, Jonathan Cornelius, Anja Gassner, Dave Harris, Constance Neely, John Lynam and Tony (AJ) Simons. 


\section{List of abbreviations and acronyms}

CBD

CGIAR

CIFOR

FTA

FT\&A

ICRAF

INDC and NDC

NAMA

REDD+

SDGs

ToC

ToIC

ToP

UNCCD

UNFCCC

WTO
Convention on biological diversity

formerly: consultative group on international agricultural research, currently described as a global research partnership for a food-secure future

Centre for international forestry research

Forests, trees and agroforestry, a CGIAR research program

Forests, trees and agroforestry, as part of the real world

International Centre for Research in Agroforestry, also known as World agroforestry centre

(Indicative) nationally determined contribution to global climate change mitigation targets

Nationally appropriate mitigation actions, as part pf the UNFCCC

Efforts to Reduce emissions from deforestation and (forest) degradation, as part of the UNFCCC

Sustainable Development Goals (adopted by United Nations in September 2015)

Theory of change

Theory of induced change

Theory of place

United Nations convention to combat desertification

United Nations framework convention on climate change

World trade organization 


\section{Introduction}

The world is more in need of integrative concepts than ever before, given concerns over planetary boundaries (Rockström et al 2009), limits to growth (Meadows et al 2004), limits to adaptation (Dow et al 2013) and the sustainable development consensus (Costanza et al 2016). Agroforestry, as currently perceived, connects the scales of tree, farm, livelihoods, landscape and governance describing practices that had so far fallen through cracks of the typologies and operational definitions used to delineate policy domains (van Noordwijk 2014; Minang et al 2015a). The concept of agroforestry can contribute at multiple scales of analysis, but current definitions refer to a single scale, while hypothesis-based research has made more progress on the biophysical-ecological than on the socio-economic and policy dimensions. Opportunities now exist to seek a new balance, but the specific meaning of the term agroforestry may well have to change along with context and scale, without losing cross-scale coherence. Simple questions such as "How much agroforestry is there in the world?", "Is it increasing or decreasing?", "Does it work?", "What is its contribution to national economies?", "Does it contribute to ecosystem services?" are still hard to answer, despite four decades of research, partly because the specific definitions used are not directly operational, and partially clash with existing categorization of national statistics. The total value of agroforestry is likely to be considerable, but it cannot be derived from FAO-STAT statistics, as agroforestry and nonagroforestry parts of the landscapes are not kept apart. While internationally traded commodities such as coffee, cacao and rubber can derive from mixed agroforestry or monocultural plantations, locally important fruits, fuelwood and timber can derive from natural forest, agroforestry and/or monocultural plantations. Common definitions are not clear on the cut-off criterion where agroforestry ends and non-agroforestry starts. In fact, a similar, but not fully recognized problem exists with the distinction between agriculture and forestry, as we will discuss below.

The language of hypotheses, their rejection and refinement as markers of progress interacting with definitions of terms that align closely with measurable quantities, is well understood in science. At the interface with policy worlds, fuzziness is appreciated initially where it helps to increase political platforms (Pielke 2007). To move to implementable policies, however, clarity of terminology and concepts is needed to allow effective communication and implementation. Effective policies need operational definitions, marking where rules apply and where they don't, without fuzziness. Policies also require solid ground of underlying knowledge, beyond what current refinements are likely to overhaul soon, as any uncertainty and doubt can be exploited by stakeholders of status quo. The levels of uncertainty associated with scientific concepts at their cutting edge can be easily misunderstood and misused as excuse for inaction (Bradshaw and Borchers 2000; Nowotny et al 2013). New ways of knowledge production and decision-making are evolving that reduce the science-policy-application gaps by early involvement between all parties involved (Lang et al 2012). 'Policies' in our context include the strategies that guide actions of many seeking to influence rural lives and landscapes, for example conservation and rural development NGOs, and for these an understanding of uncertainties can shift approaches from recommending practices to supporting decision making in a context of portfolio's of meaningful diversity, rather than assuming there is a single best solution. 
It was clear from the start of explicit agroforestry knowledge analysis, that local knowledge associated positive attributes with agroforestry as a complex system with many local attributes, while agricultural science had focussed on benefits of specialization and simplification. Subsequent formal analysis of local (or "indigenous") knowledge and perspectives showed that it can indeed be a basis for further agroforestry development (Thapa et al 1995). Some of this appreciation was for diverse tree production practices, often with early stages of domestication of species that had become appreciated as source of forest products but that did not have the status of international commodities and hence had not attracted the attention of formal research systems. Where commodities such as coffee, cacao or tea that were forest understorey species became intensified into open-sun systems a number of pest, disease and soil degradation issues emerged that made the mixed agroforestry ways of growing them appear to have lower risk. It was thus important for the credibility of agroforestry that claims on positive effects of growing crops and trees together could be tested and potential mechanisms for such interactions clarified. Any such positive effect had to be stronger than the negative effects of resource competition, however, before a net benefit could emerge. This led some leading agroforestry researchers to shift back to rotational rather than simultaneous forms of agroforestry (Sanchez 1995). Cannell et al (1996) summarized the $10-15$ hypotheses that had been formulated in the 1980's on the biophysical basis of agroforestry as efficient resource capture systems in a single, central agroforestry hypothesis, consistent with the tree crop interactions synthesis that was published around the same time (Ong and Huxley 1996). The hypothesis "benefits of growing trees with crops will occur only when the trees are able to acquire resources of water, light and nutrients that the crops would not otherwise acquire" became a well-cited agroforestry reference and played its role in stimulating and publishing further research - partly because it was open to refinement. It wasn't a truism. It was at least incomplete on the concept of "benefits", if not false as generalization. From a farmer perspective competition in mixed systems is no problem as long as the utility (local use or market value) per unit resources captured is equivalent. This criterion is more easily met with high-value, rather than low-value trees. Tree selection, improvement and domestication became the primary way to reduce farmer concerns over tree-crop competition. Horticulture has a long tradition of vegetative propagation and grafting as rapid ways to capture superior germplasm, where breeding for improved seed takes many tree generations and thus easily a human lifespan (or at least a researchers contract period). Progress was made in participatory tree domestication, based mainly on vegetative propagation and an orientation to local markets and needs (Leakey and Simons 1997; Leakey 1999; Simons and Leakey 2004). Where vegetative propagation leads to different root systems than seed-based propagation, however, it raised new questions on resource capture (Asaah et al 2012). Further scrutiny of the Cannell et al hypothesis had shown that complementarity in resource capture had to be weighted by the degree of resource limitations (Kho 2000; Ong and Kho 2015). In various aspects of belowground interactions in agroecosystems longterm resource dynamics beyond current capture were found to be important (van Noordwijk et al 2004a). Meanwhile, research on resource capture also provided a solid basis for the "lateral flows" route into understanding landscape-level processes, including non-area-based scaling (van Noordwijk and Ong 1996; van Noordwijk et al 1998; Vandermeer et al 1998; Ranieri et al 2004). The landscape oriented definition that Leakey (1996) introduced around this time coexisted with the earlier "interaction-focused" definition, but it combined descriptive elements (what agroforestry is; without clarity on what is not agroforestry) with motivational aspects (what it can possibly achieve). These 
latter elements made it hard to operationalize, and to this date there is no general agreement on the global extent (and importance) of agroforestry. It remains a fringe concept, outside of national and international statistics.

Outside of these two definitions, progress was made with the much simpler "trees on farm" or "trees outside forest" concept (Zomer et al 2009, 2014, 2016). At the $1 \mathrm{~km}^{2}$ scale of the analysis of MODISbased remote sensing imagery, one can assume that trees, agriculture and people must interact in most contexts, so no specific interaction filter was used. Zomer et al (2014) found that by 2010800 million people lived (+100 over the 2000-2010 decade) in the 9.5 million $\mathrm{km}^{2}$ of agricultural lands $(+0.5$ over the 2000-2010 decade) with $>10 \%$ tree cover, and 180 ( +20 over the 2000-2010 decade)) million people lived in the $3.5\left(+0.2\right.$ over the $2000-2010$ decade) million $\mathrm{km}^{2}$ of agricultural lands with $>30 \%$ tree cover. The forest-agriculture distinction used for that analysis has the benefit of being spatially explicit and it can be consistently applied over time. The finding that more than $40 \%$ of what is classified as agricultural lands has at least $10 \%$ tree cover and as such could qualify as forests is making inroads in the global debates on sustainable development, adaptation to and mitigation of climate change (Verchot et al 2007; Duguma et al 2014; van Noordwijk et al 2011, 2014). Claims that agroforestry is key to the Millennium Development Goals (Garrity 2004; Mbow et al 2015) received some attention, but in the 2015 formulation of sustainable development goals (17 goals to be achieved by 2030) agriculture and forestry have separate places, and space for agroforestry to be picked up in existing indicators and progress markers is limited. Mainstreaming of more integrative approaches thus remains a challenge. During the fourth decade since the term agroforestry was coined in the late 1970's a third arena has opened up, beyond the plot/farm and landscapes scales: the policy arena and the types of boundary work that allow effective two-way influence at the science-policy interface (Clark et al 2011). It had its precursors (Tomich et al 1996, 1998; Izac and Sanchez 2001; van Noordwijk et al 2001).

A new formulation of what agroforestry is and can do is needed to speak to the primary stakeholders of this arena. The policy-oriented agroforestry discourse can be seen as a new (and third) 'paradigm' of agroforestry, but it will require clarity in terms of definition, concepts, issues and hypotheses to thrive as part of the agroforestry conceptual tree. In this contribution to the debate, we will briefly review the first and second agroforestry paradigm, before describing and discussing the third. We propose a new overarching definition of the term agroforestry that is compatible with the three paradigms, interpreted as part of a nested scales concept, and formulate central hypotheses that can bring agroforestry to bear on the Sustainable Development Goals era of global discourse. In doing so, we need to keep space for further learning and evolution of the ideas, but within a framework that allows effective communication based on clarity of concepts and definitions.

\section{Terminology: Theories of place, change and induced change}

From its very start agroforestry science has been grounded in farmer reality and, as a consequence, often been at odds with government concepts, statistics and regulations, which were framed in a segregation of agriculture and forestry as separate sectors. Where in the past development agencies used "log frames" as a planning tool, that tried to manage activities towards the best chances to achieve planned positive outcomes and impacts, beyond a project lifespan, the terminology of "theory 
of change" has become common (Weiss 1997; Connell and Kubisch 1998.). The theory-based evaluation literature defined a theory of change as a theory of how and why an initiative works. This may be more specifically described as a "theory of induced change" (ToIC), with "impacts" as the difference between the trajectory of a system without intervention (but subject to external variability and change), described with a ToC and trajectory with planned interventions as well as external variability and change, described by the ToIC. As there are likely to be multiple feedbacks, rather than a simple causal pathway, clarifying our understanding of how systems work in a ToC, helps us to use information on context ("theory of place"; ToP) to ex ante predictive power that can be used in planning interventions (Figure 1). Agroforestry as a development focus requires a ToIC, but such needs to be based on generic ToC understanding of change processes, and the context of a ToP. In the emerging agroforestry science aspects of ToP, ToC and ToIC have been closely associated.

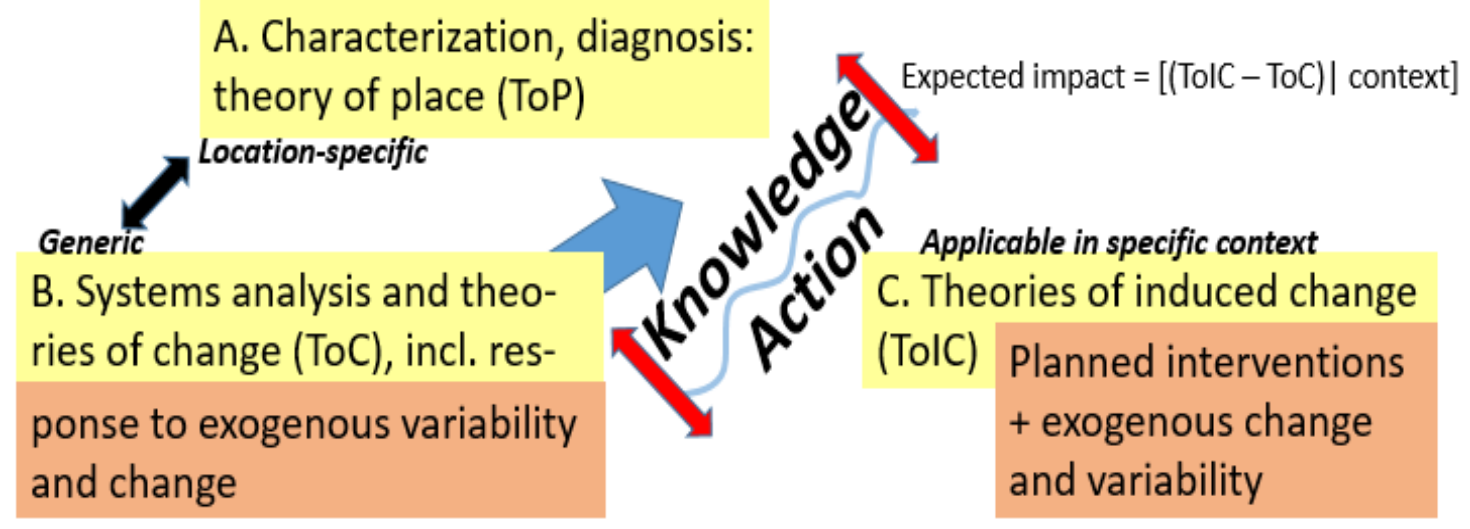

Figure 1. Three interacting domains of knowledge and praxis that need to be joined up to achieve the societal benefits agroforestry can potentially provide

\section{Definitions, concepts and hypotheses of the first agroforestry paradigm}

"Man is both creature and moulder of his environment, which gives him physical sustenance and affords him the opportunity for intellectual, moral, social and spiritual growth. In the long and tortuous evolution of the human race on this planet a stage has been reached when, through the rapid acceleration of science and technology, man has acquired the power to transform his environment in countless ways and on an unprecedented scale. Both aspects of man's environment, the natural and the man-made, are essential to his well-being and to the enjoyment of basic human rights the right to life itself." The opening paragraph ${ }^{2}$ of the declaration at the end of the 1972 Stockholm conference ("Only one earth") shifted attention back from the moon to our own planet, benefitting from the first external views on what the planet looked like when seen from outside. Agroforestry concepts were shaped in the aftermath of this, when issues of environment plus development became mainstreamed. In the early formative years of agroforestry as a concept and specifically in shaping the agenda of a global

\footnotetext{
${ }^{2} \mathrm{http}: / /$ www.unep.org/Documents.Multilingual/Default.asp?DocumentID=97
} 
centre set up in 1978 to compile information, communicate, explore and improve, a number of strands came together.

Box 1. First ICRAF articulation of concepts and purpose of agroforestry research

CONCEPTS OF AGROFORESTRY. BY K. F. S. KING Director-General (INTERNATIONAL COUNCIL FOR RESEARCH IN AGROFORESTRY)

"The existence of large numbers of people In the fragile ecosystems of the developing world, and the fact that these ecosystems occupy the greater proportion of the land of the developing economies suggest that means must be devised which will assist in increasing the productivity of these ecosystems while at the same time either rehabilitating them or arresting the process of degradation. Agroforestry is a system of land management which seems to be suitable for these ecologically brittle areas. It combines the protective characteristics of forestry with the productive attributes of both forestry and agriculture. It conserves and produces. It is suggested that if the concepts of competition among plants are understood, and appplied in the practice of the system of agroforestry, the system would achieve the objectives that have been stated above. The important considerations are that species must be chosen for their complementarity, and for their ability to utilise in harmony water, nutrients and solar energy, over time."

http://www.worldagroforestry.org/downloads/Publications/PDFS/01_Concepts_of_agroforestryv1.pdf

Traditional interests by forestry institutions to interact with farmers focussed on what were perceived to be mutual benefit relations in allowing farmers to grow their crops in the early years of forest plantations (with the trees owned by the (state) forestry company; Evans 1992). These systems became known internationally as "Taungya", although that term had a different meaning in parts of mainland SE Asia, in Indonesia as "Tumpangsari" and in Kenya as "Shamba system". All of these proved to be controversial in subsequent analysis. A second strand of agroforestry interest came from the issues of land degradation and restoration, including the specific aspects of sloping land erosion and coarse grasslands replacing forests, with high hopes that agroforestry could provide a new opening to achieving locally led land rehabilitation, where topdown forestry based approaches had a mixed record at best (King 1987). A third strand of early agroforestry interest was in the full spectrum of homegardens and shaded tree-crop production systems (especially coffee and cacao) (Torquebiau 1992; Huxley 1999). A fourth strand was the "multipurpose trees" focus on woody species beyond the specialized timber selection lines of foresters and fruit tree producers of horticulturalists. Extensive databases were constructed, leading to the current AgrofesTree database (Orwa et al 2000). Biological nitrogen fixation through trees deserved specific attention (Dommergues 1987; Giller Cadisch 1995; Giller 2001). A sixth strand was the storyline of agroforestry as alternative to green-revolution style specialization and intensification. In the strongly polarized world of development discourse, this perspective on agroforestry gradually shifted to the "permaculture" concept, when agroforestry institutions did not pick up this branding opportunity. Academically the concept of mimicking natural ecosystems in agroforestry had some traction, but analysis also quickly showed limitations to the concept (van Noordwijk 1999; van Noordwijk and Ong 1999). 
Inventories, classification and typologies of the many land use practices that can be called "agroforestry" were a major concern in the early days. Along with those, the definition of what is agroforestry (and hardly on what it is not...) received ample attention (Nair 1985 1993; revisited by Sinclair 1999 and Torquebiau 2000). This inventory stage lead to the widely accepted definition: Agroforestry is a collective name for land-use systems and technologies where woody perennials (trees, shrubs, palms, bamboos, etc.) are deliberately used on the same land-management units as agricultural crops and/or animals, in some form of spatial arrangement or temporal sequence. In agroforestry systems there are both ecological and economical interactions between the different components.

Tree-soil-crop-livestock interactions were key to this first generation agroforestry concept, with its focus on the trees and the plot-level interactions (Nair 1998). In the same time, some farm economic analysis started (Hoekstra 1987; Swinkels and Scherr 1992; Swinkels et al 1997), and a landscapelevel problem solving approach "Diagnose and Design" (Raintree 1987).

The interaction-focused definition, became the basis of an initial set of ten hypotheses ("Agroforestry can achieve ..."), with some subsequent additions. These hypotheses served a function in triggering compilation of evidence, but it was clear from the start that while specific form of agroforestry A, in context K could achieve X, this didn't give much predictive power for other forms of agroforestry in other contexts nor on the way possible achievements X, Y and Z were part of a tradeoff, or could be jointly achieved. Even in seemingly the same situation fine-scale variation could substantially influence results, urging for full randomization with sufficient replication in field trials, distributed throughout the intended recommendation domain. Reviews by Ong et al (1991), Rao et al (1998) and van Noordwijk et al (2004a) (Figure 3) made these points on the need for better contextualization with increasing power and based on an increasing empirical evidence base.

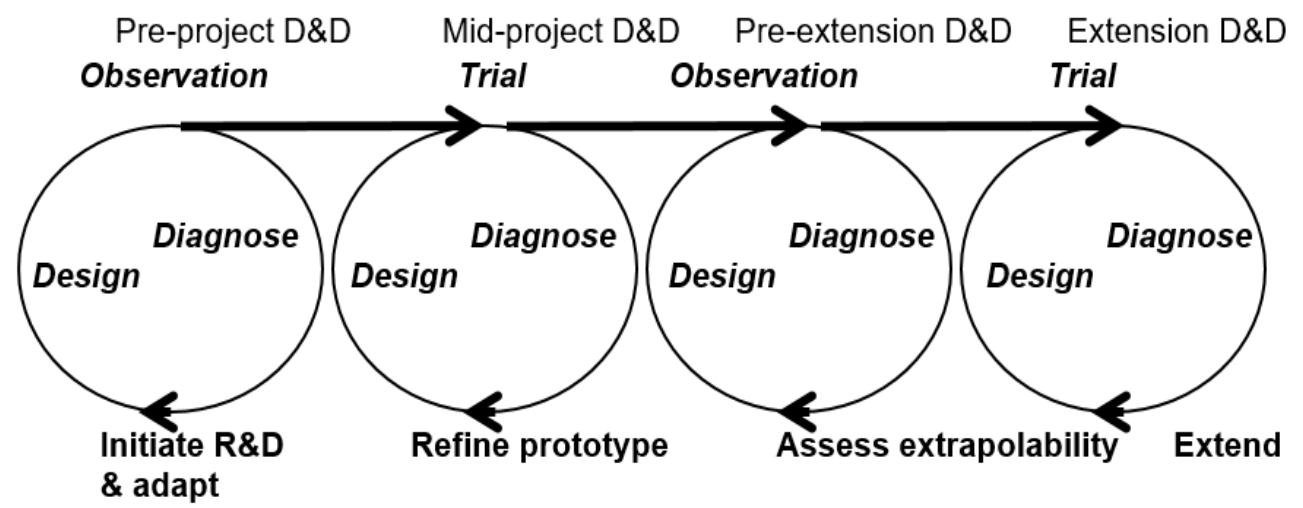

Figure 2. Representation of multi-phase "diagnose and design" (D\&D) learning loops and project cycles thirty five years ago (ICRAF, 1982) 


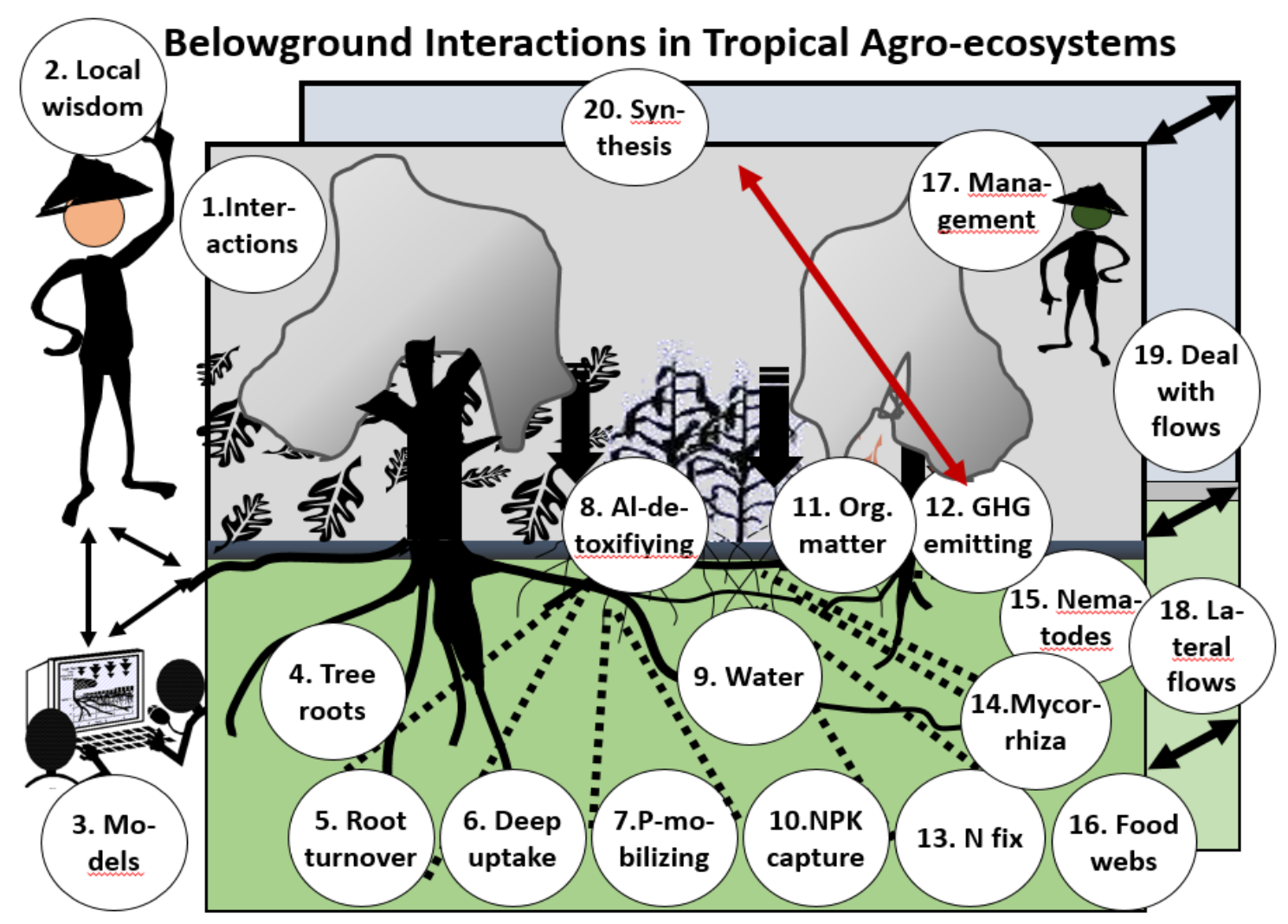

Figure 3. Aspects of belowground interactions reviewed as part of the overarching agroforestry hypothesis focused on resource capture and dynamics (van Noordwijk et al 2004a)

Building on the initial focus on erosion and its prevention (Young 1997), aspects of soil fertility, carbon, nutrient and water balances became a strong research interest (Sanchez 1994, 1995; van Noordwijk 1989). It built on concepts of intergated soil fertility management (Sanchez and Salinas 1981) and the process-oriented research on tropical soil biology and fertility (Cadisch and Giller 1997; Palm et al 2001). On the interface with policy discourse, the language of investment in replenishment of soil capital emerged and achieved some traction (Sanchez et al 1997; Giller et al 1997). However, lack of real-world outcomes of policy change in this arena meant that Africa stayed on an expansion (extensification) trajectory, where Asia was primarily increasing intensity of existing agricultual lands. Not dealing with soil fertility issues, implied the choice between continued land hunger or human undernutrition (Sanchez 2002). van Noordwijk et al (2015) provided an overview of ICRAF soil research in these phases. The ambitions to contribute to the major agronomic issues of this time through improved soil management, with trees largely in supporting roles, increased as part of the shift from ICRAF, started as "council", to a "research centre". In the late 1980's discussions started that led to ICRAF joining the CGIAR, while also initiating a new forest-focused research centre (CIFOR). This shifted the agenda to a stronger research focus, with hopes that technologybased solutions for land use issues could contribute to the global environmental agenda that took shape in the Rio conventions, 20 years after the Stockholm 1972 conference. 
Box 2. Some highlights of agroforestry research and development at ICRAF in the first agroforestry paradigm $^{1}$

- $1978 \rightarrow$ Land restoration focus, linking erosion to nutrient depletion (Young, 1997) Taungya-AF ('social forestry') as subset of forest management (King, 1987),

- $1980 \rightarrow$ Inventory of existing AF systems of the world, definitions and terminology (Nair, 1985) diagnose*design procedure for context-specific AF options (Raintree, 1985), engagement with extension, national networks,

- $\quad 1982 \rightarrow$ AF experiments with planned comparisons, supporting process-level research on simple AF systems (dominated by hedgerow intercropping) (Huxley, 1999); farm economic analysis (Hoekstra, 1987),

- $1985 \rightarrow$ "Ten AF hypotheses", focused on biophysical benefits/effects; -> 1995: central AF hypothesis on complementarity in resource use (Cannell et al 1995).

- $1988 \rightarrow$ Using functional diversity of tree species as basis for process level understanding of key tratits (Hairiah et al 1992; Rao et al 1998),

- $1991 \rightarrow$ Mechanistic (process-based) models of the biophysical interactions in agroforestry start to emerge (Mathews et al 2004; Luedeling 2015).

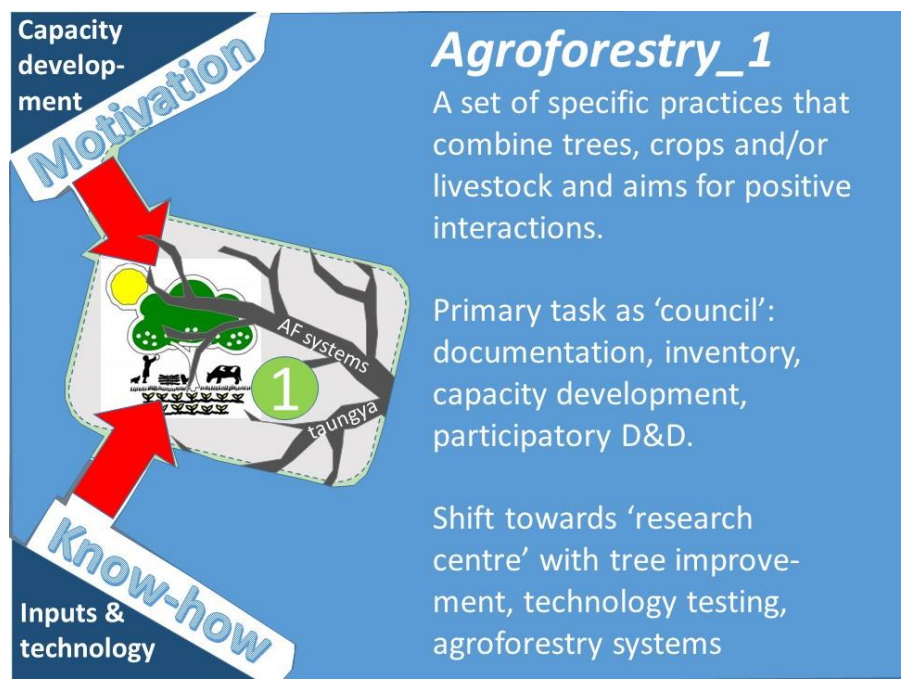

${ }^{1}$ References often refer to later summaries of research directions in which the original ICRAF studies are cited

Where most of the CGIAR centres had had major success with breeding new cultivars of their target species, agroforestry research spend considerable time and effort to prioritize the species most worthy of such interest. Various ways of selecting species and the traits to be used in selection were compared (Wood and Burley 1991; Franzel et al 1996), but the realization of the wide range of species and wide range of contexts raised doubt on the concept. The agroforestry species with the most successful tree breeding and selection program, Leucaena leucocephala, meanwhile demonstrated the risk of loosing intraspecific diversity: the miracle tree was wiped out by a rapidly spreading psyllid pest throughout the tropics (Shelton and Brewbaker, 1998). Subsequent tree 
improvement efforts have been more local in scope, with emphasis on modifying existing farmer-tofarmer exchange and local collections, rather than "designer" tree approaches removed from farm realities. The molecular toolbox of current genome mapping may help primarily in more effective screening and early selection procedures, supporting rather than replacing local domestication efforts. Farmers' preferences and use of local fodder trees became a line of research with direct development outcomes (Roothaert and Franzel, 2001), while it was realized that the emergence of trees of prosperity for Africa depended on a thorough understanding of the markets and smallholder choices (Russell and Franzel, 2004), beyond what earlier species prioritization schemes had been able to capture. Van Noordwijk et al (2008) found that barriers to smallholder tree planting include many factors beyond tree germplasm and its genetic quality.

Wiersum (1997) had also broadened the domestication concept from human control over the biology of a species, to the inter-human issues of resource access, suggesting that issues of tenure are as important for successful domestication as knowledge of the DNA. This fitted well with a further broadening of the domestication concept. The domestication concept was found to be applicable at the forest level as well as the trees (de Foresta and Michon 1994; Michon and de Foresta, 1996; Michon 2005; Michon et al 2007). A formative aspect of the transition to the second agroforestry paradigm was the "discovery" of the damar agroforests in Krui (Lampung, Indonesia) (Torquebiau, 1986) as a late successional stage of coffee gardens, but so similar to natural forest that they had been misclassified as such, with the risks that logging concessions could be issued by the Ministry of Forestry. Specific policy change for this setting was a major achievement (Kusters et al 2007, 2008), setting the tone for a much wider challenge to the way forests are defined and managed in the landscapes of Indonesia (Fay and Michon 2005).

At the transition from the tree and plot level first agroforestry paradigm to the second, focussed on landscapes and livelihoods, a number of factors contributed: new experience in other parts of the tropics, increased ambition to contribute to the major issues of this time, and emerging insights in the systems scales and its feedbacks.

\section{Definitions, concepts and hypotheses of the second agroforestry paradigm}

"Agroforestry is a dynamic, ecologically based, natural resource management system that, through the integration of trees on farms and in the agricultural landscape, diversifies and sustains production for increased social, economic and environmental benefits for land users at all levels." Leakey (1996) redefined agroforestry in a way that went beyond "what it is" to "what it does" and "why we believe in it". These latter aspects made it difficult to articulate what is not agroforestry. If integration of trees on farms and in the agricultural landscape, is found not to diversify and sustain production, or when this does not increase social, economic and environmental benefits for land users at all levels, it isn't agroforestry. Agroforestry is protected from all blame or negative press - but it is hard to say how much agroforestry there actually is in the world, whether it is increasing or decreasing, and what its further empirical properties are. Despite such criticism on the new definition, the broadening of the concept of agroforestry to landscape scale and attention to the tradeoffs between social, economic and 
environmental aspects (either promoted as win-win-win solutions, or empirically tested on the various tradeoffs) proved to be key to the further growth of agroforestry as its second paradigm.

The landscape scale definition of agroforestry also supports the analysis of contributions of trees to farming households as the landscape of small holder systems often does not resemble an assembly of discrete areas of different 'technologies'. It is more usually a mosaic of patches of land with different land use intensities, each patch with fuzzy, overlapping and temporary boundaries.

Strong support for a landscape approach to agroforestry came initially from the way it matched the experience in watershed management. Plot-level interventions need to be understood in their interactions with all overland and subsurface flows to assess impacts on downstream water quantity, quality and regularity of flow (van Noordwijk et al 2005). Biophysical research on erosion and its counterpart process of sedimentation showed that net sediment loss estimates are strongly dependent on the scale of assessment (van Noordwijk et al 1998), and that most map-based extrapolations that assume area-based scaling can be several orders of magnitude off at the continental scale. A specific aspect of that is that it is still contested whether erosion is a net contributor to landscape scale carbon sequestration or emission (van Noordwijk et al 1997; Paustian et al 1997; Doetterl et al 2016).

The landscape focus was further strengthened when the concepts used in the analysis of intercropping at plot level could be applied for systems with multiple functions. Under some conditions it is indeed an efficient use of land to combine them in integrated, multifunctional land uses, under other conditions it is better to keep them spatially segregated. The segregation-versus-integration discussion (Van Noordwijk 1998a) came back in the international arena a decade later as "land sparing" versus "land sharing" (Van Noordwijk 2012b; Villamor et al 2014). The land sparing perspective expected major benefits for conservation elsewhere of intensifying land use within agriculture. The second agroforestry paradigm was embraced in efforts at the tropical forest margins by the ASB consortium to develop coherent alternatives to existing land uses. Figure 4 (Minang et al 2014a; Clark et al 2011) summarizes the various theories of change that program considered and mostly rejected, or found in need of further nuance and contextualization. The initial theory (Sanchez 1994, 1995) corresponded with the Borlaug hypothesis and expected that the development of intensified alternatives not only would achieve higher yields per unit land on the locations where it would be implemented, but also that this would reduce pressure on forests elsewhere and as such help to conserve forests. In subsequent research ASB scientists focussed on quantifying the tradeoffs between productivity and ecosystem services. Where forest margin situations are typically labour- (rather than land) constrained, the returns to labour where found to be a key performance indicator, next to the Net Present Value of land. The existence of extensive rubber agroforests were a case in point (Gouyon et al 1993), with a long history of outcompeting intensified plantations rather than the other way around. The analysis of agroforestry options required truly interdisciplinary efforts, building on concepts of economists, ecologists, social and political scientists, as well as on agronomists and agroforesters (Tomich et al 2005, 2007). Next steps in this chain was the exploration of economic incentives for ecosystem services as a potentially efficient use of public resources to achieve environmental goals for society (Tomich et al 2004a,b). The subsequent experience was that a balance between fairness and efficiency dimensions need to be found, and that a language of coinvestment is more likely 
Box 3. Some highlights of agroforestry research and development at ICRAF in the third agroforestry paradigm

- $1993 \rightarrow$ Out of Africa expansion; landscape-systems based hypotheses for restoring degraded lands, shifting pressures at tropical forest margins and dealing with sloping lands and erosion, the discovery of the "agroforest" (Michon et al 1986. Gouyon et al 1003; De Foresta and Michon1996).

- $1994 \rightarrow$ Participatory tree domestication as opportunity to add value to trees, combining biological and socio-economic aspects and effective information sharing, with specific local context and actors; shift from trees in soil fertility service roles to trees that bring money to farmers' pockets (Leakey and Simons 1997).

- Continued work on land degradation starts to look beyond plot-level interventions (Cooper et al 1996) and links in with forest transition theory (Rudel et al 2001).

- Agroforestry pathways for intensifying shifting cultivation and fallow manegement (Raintree and Warner 1996; Cairns and Garrity 1999).

- $\quad 1995 \rightarrow$ Imperata grasslands as new focus for systems approach to land rehabilitaiton (Garrity et al 1996; De Foresta and Michon 1996; van Noordwijk et al 1996; Tomich et al 1996); tradeoff and multifunctionality concepts across all land use options in tropical forest margin landscapes in ASB opens new policy engagement linking local to global scales (van Noordwijk et al 2001; Izac and Sanchez 2001).

- $1995 \rightarrow$ African Highland Initiative (Wang'Ati, 1994) brings focus on local community and governance scales, research participation in local change.

- $1998 \rightarrow$ Landcare emerges as dynamic local action platforms (Mercado et al 2001); explicit attention to marketin aspects of agroforestry products (Russell and Franzel 2004).

- $2000 \rightarrow$ Ecosystem Services aspects become explicitly part of the agenda (Van Noordwijk et al 2001; Tomich et al 2004a; Tomich et al 2005; Jose 2009).

- Tree diversity analysis at landscape scale emerges (Kindt and Coe 2005).

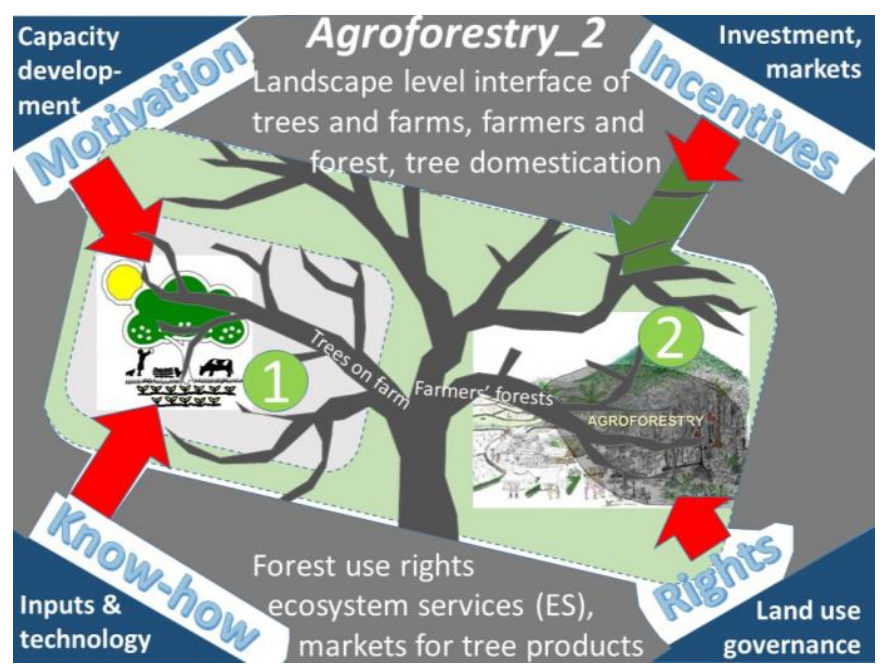


to succeed than one of payments for ecosystem services (van Noordwijk et al 2007b, 2012a; Leimona et al 2009, 2015). This proved to be an important experience that could be shared in the global discussion on REDD+ (reducing emissions from deforestation and forest degradation) (van Noordwijk 2014b; Minang and van Noordwijk 2014).

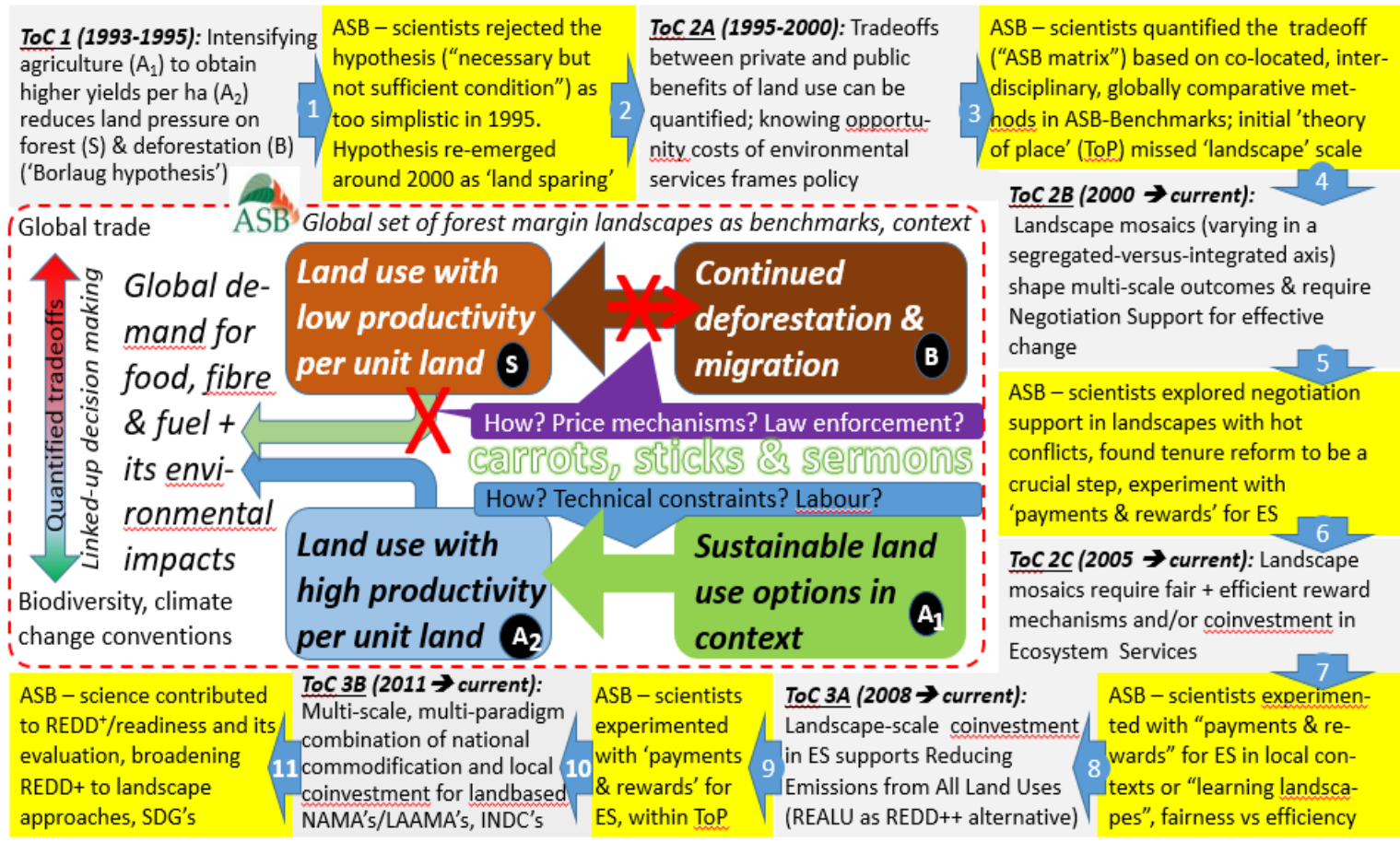

Figure 4. Example of the learning curve and continuous refinement of "Theories of Change" (ToC) in a longterm partnership program for tropical forest margins, gradually building up its Theory of Induced Change (Minang et al 2014a)

Simultaneous with ASB, the African Highlands Initiative (AHI) (Wang'Ati 1994; German et al 2013) started as an ecoregional programme that focused on natural resource management (NRM) research in the densely populated highlands of Eastern Africa. It build on the D\&D traditions, with strenghtened participatory research as an effective approach to the development and dissemination of NRM technologies. Outcome monitoring was being used to characterise and assess in detail the changes in behaviour of researchers and farmers as they engaged in community-based participatory research activities (Opondo et al 2003). The innovation in outcome monitoring shifted the sole assessment of technical outputs of research programmes towards focusing on the changes in the behaviour, relationships and actions of people and organisations required for implementing quality participatory research. AHI research developed a strong focus on watershed management (German et al 2007) and the understanding of local bylaws, collective action and local governance systems (German et al 2012; German et al 2013). The social scientists involved felt they were still misunderstood and misused as "anthro-apology" (Verma et al 2010): "Equitable interdisciplinary teamwork is easier said than done. For, it is not simply a matter of adding a "pinch" of social science into a larger interdisciplinary team, and stirring. Putting interdisciplinarity into action requires a more distilled and nuanced approach involving negotiation, bargaining and, sometimes, contestation and resistance between and among different domains of disciplinary actors, knowledge, meanings and 
understanding. The overarching goal for anthropologists and sociocultural scientists is to integrate theories, methodologies, and practices of the study of culture, politics, and social relations into agricultural and natural resource management research, as well as to integrate themselves into larger interdisciplinary teams on an equal footing."

Meanwhile, as the ASB research had been one of the earliest global comparative studies where consistent measurements were made in the three continents with humid forests, its data on carbon stocks and greenhouse gas emissions (Palm et al 2004) and biodiversity (Swift et al 2004; Gillison et al 2004; Minang and van Noordwijk 2013) proved to be valuable, when the global debate on REDD+, its likely co-benefits and institutional setup took centre stage in the UNFCCC. The search for climatesmart landscapes, combining adaptation and mitigation perspectives at multiple scales stimulated a recent synthesis on landscape approaches (Harvey et al 2014; Minang et al 2015).

The landscape scale definition of agroforestry opened up to new categories of human benefits. Trees provide resins and fruits, some of which are caloric staple foods and many are important dietary sources of vitamins (Jamnadass et al 2013). Siegel et al (2014) compared availability of fruits and vegetables with what is considered necessary for a healthy diet and found a global deficit of $22 \%$, with 58\% in low-income and -2\% in high-income countries. This deficit in (tree-based) fruit and vegetable supply coexists with oversupply (relative to a healthy diet) of protein sources and caloric staple foods that are more easily stored and traded over long distances. Chaplin-Kramer et al (2014) recently showed that the primary sources of micronutrients in diets are far more pollinator dependent than the staple food crops that provide calories -- and trees in agricultural landscapes with their understory can support pollination functions, although further quantification is desirable.

Our understanding of the adoption potential in Sub-Saharan Africa of agroforestry as a technology has increased substantively (Franzel et al 2001) from the early days when a homogeneous population of farmers were expected to be hungry for externally generated technology and eager to adopt anything presented as a development package. In her study of economic factors in farmer adoption of agroforestry in the Siaya and South Nyanza Districts in western Kenya, Scherr (1995) found evidence in support of three hypotheses: 1) Historical increases in tree domestication and management intensity are responses to declining supply of uncultivated tree resources, increased subsistence and commercial demand for tree products, and perceived risks of ecological degradation. Adoption of agroforestry is most likely where consistent with economic incentives for land use change; 2) High variability in individual farmers' tree-growing strategies reflects differences in resources and livelihood strategies, and household-level returns to agroforestry relative to alternative options for meeting specific objectives., and 3) Farmers reduce risks associated with new agroforestry practices through incremental adoption and adaptation, and cost- and risk-reducing modifications in technology design. Subsequent analysis by Kiptot et al (2007) discussed the categories of adopter, testers and pseudo-adopters in the response to "new" agroforestry technologies for the area. Kiptot et al (2006) discussed farmer-to-farmer knowledge transfer in this context of understanding the diversity of farmers resources and objectives, while Phiri et al (2004) analysed the association of wealth status and gender with the planting of improved tree fallows.

The landscape-scale understanding of ecosystem services (MEA 2005) and the way these are influenced by forests, trees and agroforestry required articulation of the interactions of scales, flows and filters with property rights and collective action in watershed management (Swallow et al 2002, 
Van Noordwijk et al 2007a). Beyond regulation of allowable land use in view of the risks of landslides, erosion and increased downstream flooding, the more subtle use of economic incentives (Tomich et al 2004b; van Noordwijk et al 2004b; Swallow et al 2009) became a new focus for agroforestry research. The promise of financial support for afforestation and reforestation as part of the Clean Development Mechanism (CDM) raised expectations, but also concerns about the additional water use tree planting might bring to already water constrained climate zones (Zomer et al 2008). The A/R-CDM policy window proved to be much smaller than envisioned, at least in part because of its dependence on an operational forest definition that emphasized institutional dimensions, rather than tree cover (van Noordwijk et al 2008). Meanwhile, lessons learnt with payment for environmental service schemes were summarized in van Noordwijk et al (2012a), Namirembe et al (2014) and Leimona et al $(2009,2015)$. It led to a suite of appraisal tools in the negotiation-support toolkit for learning landscapes (van Noordwijk et al 2013). Key element of these methods is the analysis of local and scientific knowledge in comparison with how issues are understood and defined in the public debate and existing policies.

\section{Emergence of a third, policy-oriented agroforestry paradigm}

The landscape scale led to a rebalancing of effort between biophysical, socioeconomic and policy orientation of agroforestry research, gradually leading to what we now recognize as the third agroforestry paradigm. Issues of rights, ownership, conflicting state and traditional institutions, such as encountered in the damar agroforests of Krui proved to be the tip of an iceberg. Everywhere researchers started to explore the relationship between local communities and forests at landscape scale, conflicts emerged, even though "community forestry" had been officially embraced by forestry institutions decades ago. Further analysis showed that part of the problem was the way forests are defined in the context of land policies. Historically, the word forest is derived from the boundary on maps that separates village territory from the lands belonging to the state (or its ruler) (van Noordwijk 2014). While negotiated solutions between local villages and forest institutions can emerge within existing rules (Akiefnawati et al 2010), the transaction costs are high and the levels of distrust are major obstacles to overcome.

International forest statistics have for several decades been compiled by the FAO. Over time, however, change in forest statistics was found to depend on changes in operational forest definition, as well as change on the ground. Part of that problem could be overcome by more systematic study of "trees outside forest" (de Foresta et al 2015).

Where agroforestry experiments in France in the 1990's had shown success from a combined productivity as well as economic perspective, there was a problem with existing rules and subsidy schemes for forests and agriculture, that assumed that these were separate domains. This sparked considerable debate, culminating in 2013 in formal inclusion of agroforestry in the Common Agricultural policy in providing financial support for "Establishment of agroforestry systems". Article 23 of Regulation 1305/2013 of the European Parliament defined: "agroforestry systems means land use systems in which trees are grown in combination with agriculture on the same land. The minimum and maximum number of trees per hectare shall be determined by the Member States taking account of local pedo- climatic and environmental conditions, forestry species and the need to ensure 
sustainable agricultural use of the land." A new effort is now under way to understand the historical demise of agroforestry in Europe (Nerlich et al 2013), as well as its current extent (den Herder et al 2015; Burgess et al 2015). Interest in revival of traditional agroforestry landscapes such as the Dehesa in Spain is mounting (Gaspar et al 2016).

Agroforestry, optimistically described as the future of global land use (Garrity 2012), has competed with a multitude of terms used to describe innovations: Evergeen agriculture (Garrity et al 2010), Ecoagriculture (McNeely and Scherr 2003), and Climate Smart agriculture. The terms change faster than the world they seek to describe. To move from interesting concept to implementable policies, however, greater clarity of terms is needed. In the perspective of Figure 5a, agroforestry has four important boundaries or interfaces that may need delineation: 1) with nature conservation, especially in landscapes where traditional low-external-input agricultural practices are restored or retained, 2) crop production, 3) animal production and 4) forests. The latter is complex as the word forests itself can range in meaning from intensively managed monocultural tree plantations to fully natural woody vegetation, and everything in between. In the similar representation (Figure 5b) by the AgForward project in the European Union (den Herder et al 2015), the top corner is labelled as trees rather than forest and crops and livestock corners are mirrored, but otherwise similar ideas of a continuum are expressed, with agroforestry occupying the central space.

Box 4. Some highlights of agroforestry research and development at ICRAF in the fourt agroforestry paradigm

- $2005 \rightarrow$ A policy-oriented climate change agenda gains prominence in agroforestry,

- $2008 \rightarrow$ Boundary work perspective on linking knowledge with action gets articulated (Tomich et al 2004c; Reid et al 2006; Kristjanson et al 2009; Clark et al 2011)

- $2011 \rightarrow$ India's agroforestry policy as first of its kind is taking shape, rejecting definitional segregation of agroforestry from both agriculture and forestry

- $2015 \rightarrow$ Agroforestry articulation as part of the Sustainable Development Goals debate

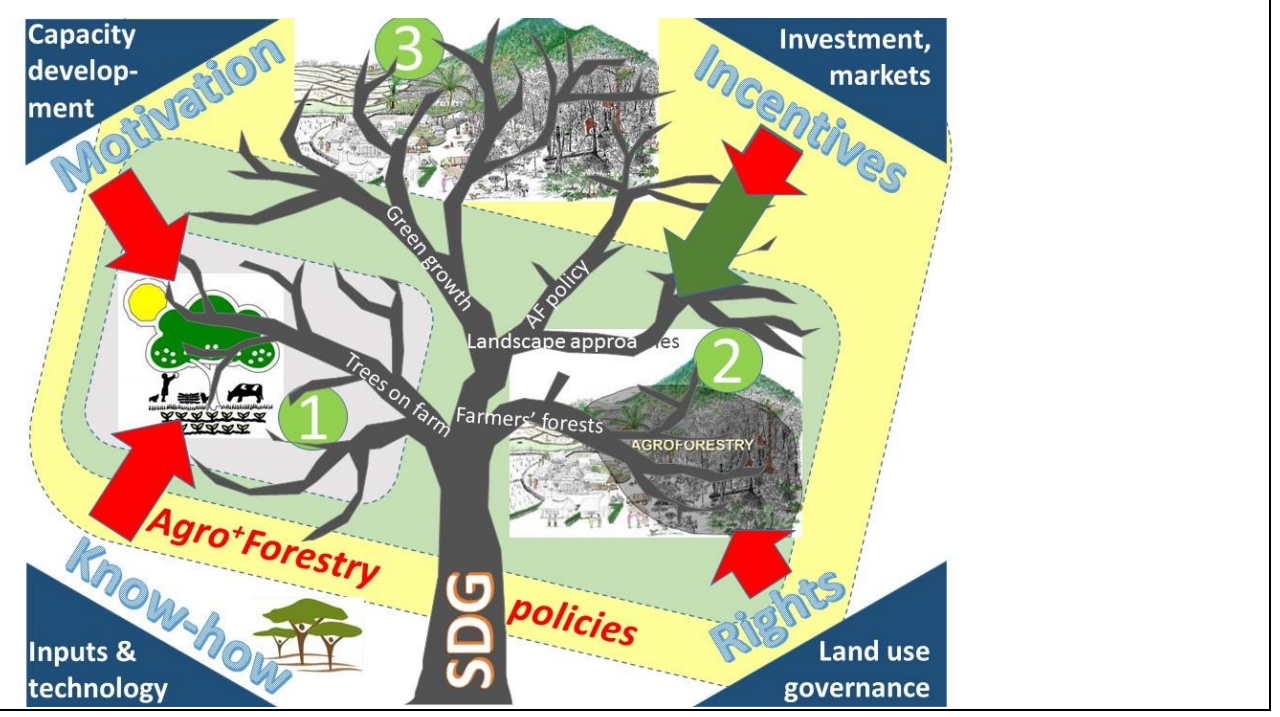


(a)

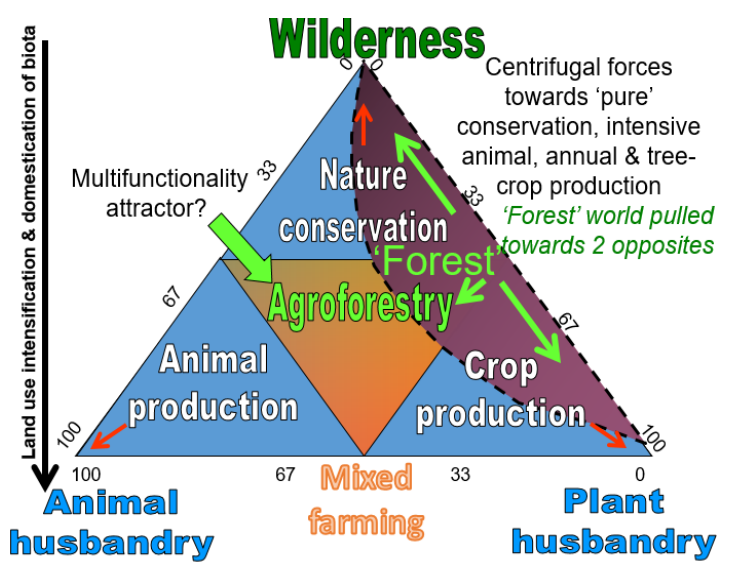

(b)

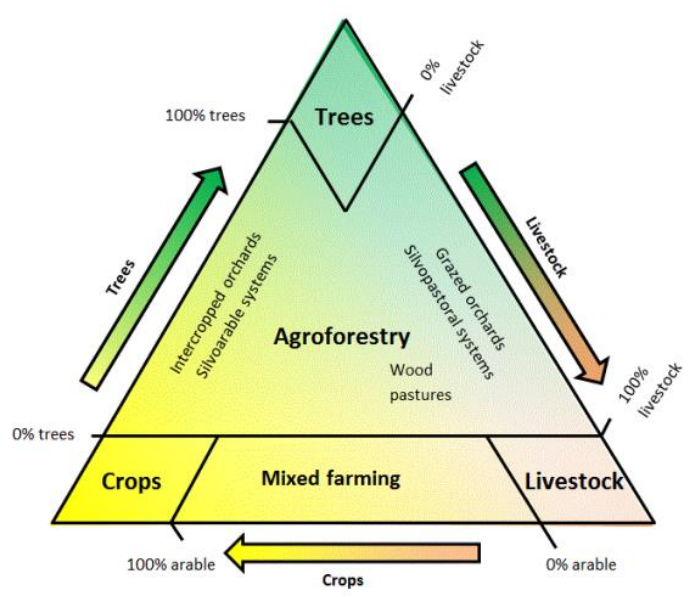

Figure 5. Representations of agroforestry as the central part of a land use triangle, (a) developed by the authors of this working paper, (b) AGFORWARD project is promoting agroforestry practices i.e. the integration of trees with farming. Agroforestry comprises the integration of trees (and shrubs) with crop and/or livestock systems http://www.agforward.eu/index.php/en/ den Herder et al 2015

A remarkable return of trees to the landscapes of southern Niger has been documented and analyzed, with more than 5 million hectares in the Maradi and Zinder Regions of Niger regreening (Sendzimir et al 2011). No single actor, policy, or practice appeared to be behind this success (Torquebiau and Taylor 2009); rather, multiple actors, institutions and processes operated at different levels, times, and scales to initiate and sustain this reforestation trend. In much of francophone West Africa the forest code inherited from the colonial period declares all trees to belong to the state, giving farmers little incentive to allow trees to grow. The reforestation cycle may well have started with benign neglect of this code, rather than active policy reform. When the initial success of an increase of tree cover in the hands of farmers was noted, the official policy was revised, creating a positive feedback loop where there had been a negative one. A recent study by Binam et al (2015) estimated the positive impacts of this re-treeing by farmer-managed natural regeneration to be an increase in the value of the products harvested from trees by about 34-38\% along with an increase of the dietary diversity by about 12 $14 \%$. The discussion on how shifting rainfall patterns coincided with, supported and possibly themselves were influenced by this retree-ing continues.

When the government of India became interested in supporting agroforestry because of the various benefits this can have, the issue of definitions proved to be a major bottleneck. The Indian nation has maintained the system of forests as "state within the state" from colonial times, even though part of these forests no longer have much tree cover, but primarily serve as source of fodder. Outside forests, fast-growing timber trees (especially poplar) became a major industry and income source for farmers, but active policy support required definition of the threshold conditions for such policy. After many deliberations the committee came to the conclusion that there would be no fully satisfactory way of defining agroforestry as different from forest, nor for agroforestry to be different from agriculture. The elegant solution was to try to do away with any of these distinctions and have the agroforestry policy based on a commitment to remove existing ambiguities and inconsistencies in the agriculture forestry interface. Existing policies on either side were meant to apply to both, with additional funding programs to make this transition work. The emerging view was that separating an 
agroforestry policy domain on both sides, from agriculture as well as from forestry, is likely to create more ambiguity and obstacles than a radical open border approach.

This Indian agroforestry policy, along with the European Union and Niger examples, marks the emergence of a third, policy oriented paradigm in agroforestry that goes beyond the landscape approach and seeks to harmonize existing policies, regulations and institutions on the agricultureforestry interface. The primary way to overcome the resistance from vested institutional interests, is to refer to the larger-scale societal benefits a return of trees to landscapes can have. The ecosystem services discourse, as well as sustainable development goals and agreed climate mitigation measures all point in the same direction. The third agroforestry paradigm, however, from its start needed to maintain consistency with the previous two, and could do this by reference to a "nesting" articulation of system scales (Figure 6).

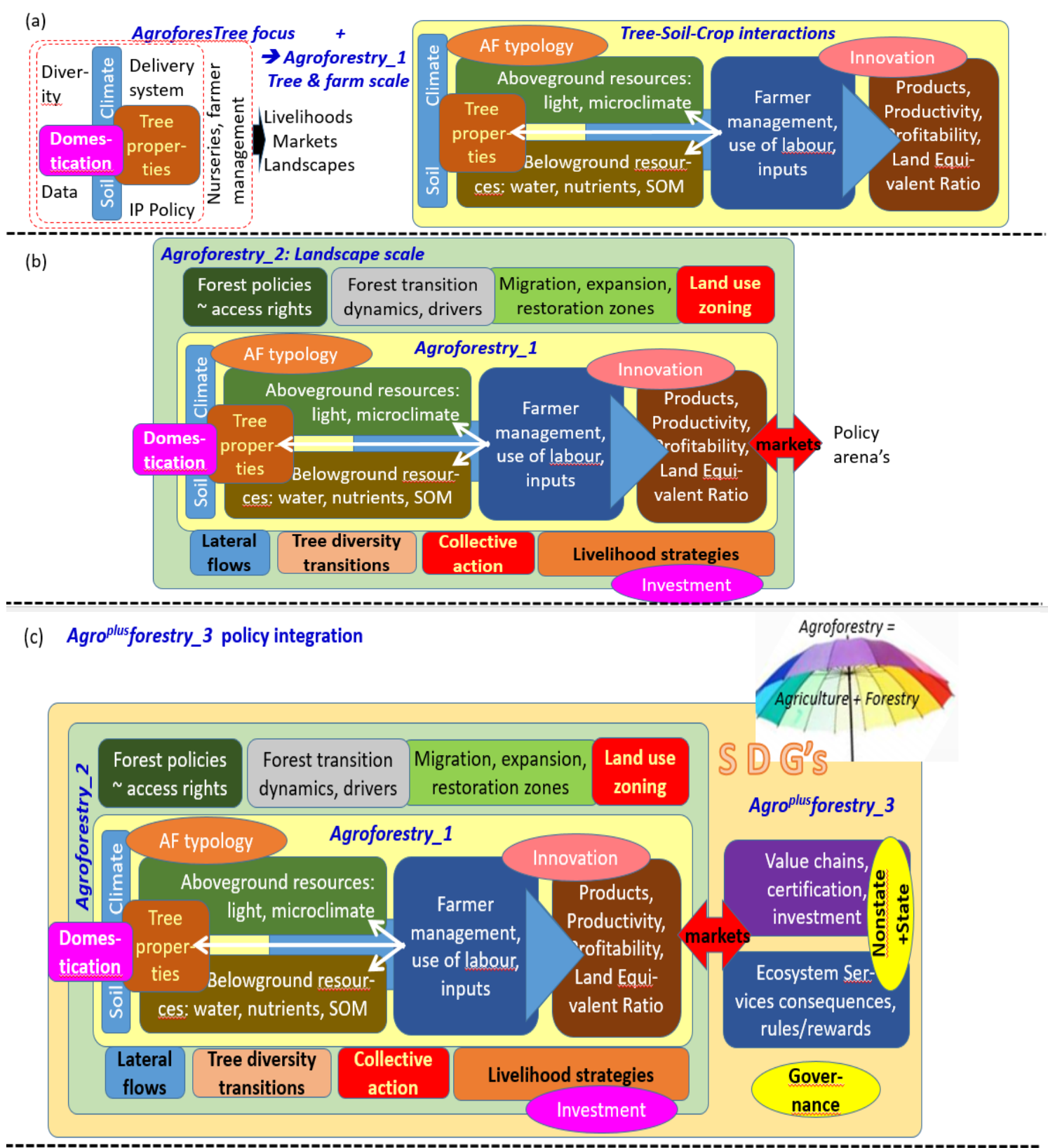

Figure 6. Three agroforestry concepts of increasing complexity and degree of nesting 
The three concepts can be mapped on the interface of agriculture and forestry (Figure 7). Four ways agroforestry concepts can contribute to SDG's are (van Noordwijk et al 2015):

1. Agroforestry as a land use system in-between forest and open-field agriculture, can - with appropriate combinations of trees, crops and livestock - provide a range of goods, benefits and services simultaneously, providing nutritious food, renewable energy, and clean water, while conserving biodiversity.

2. By allowing efficient, multifunctional land use (technically speaking, with a Land Equivalent Ratio > 1) it supports "sustainable intensification"

3. Agroforestry as institutional response to contested resource access, allowing gender and social equity enhancement and source of empowerment

4. Agroforestry as integrative mindset and culture can help create synergy between the various SDG's in multifunctional landscapes, break out of institutional silo's

Agroforestry_1

A set of specific practices that combine trees, crops and/or livestock

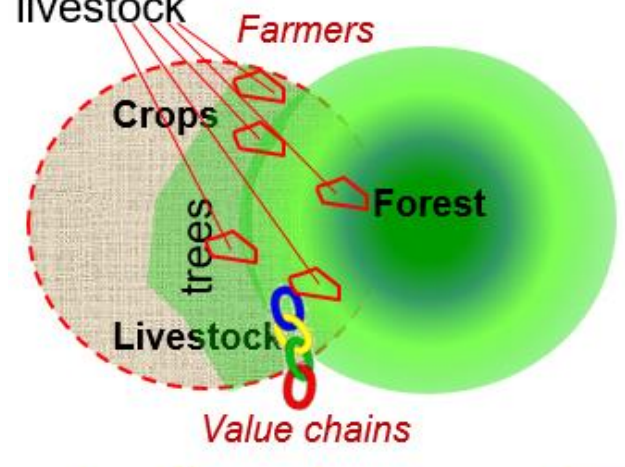

\section{Agroforestry_2}

The intersection of farmers and forest + all trees in agricultural and multi-functional landscapes

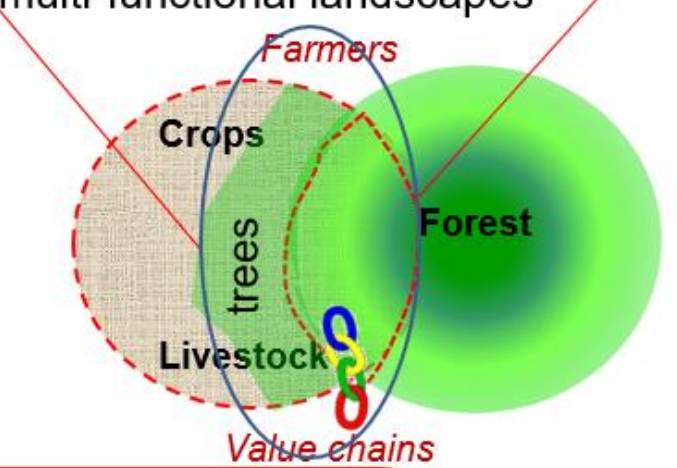

Agro ${ }^{+}$forestry_3 The combination and interface of all agriculture and forestry issues, without institutional barriers

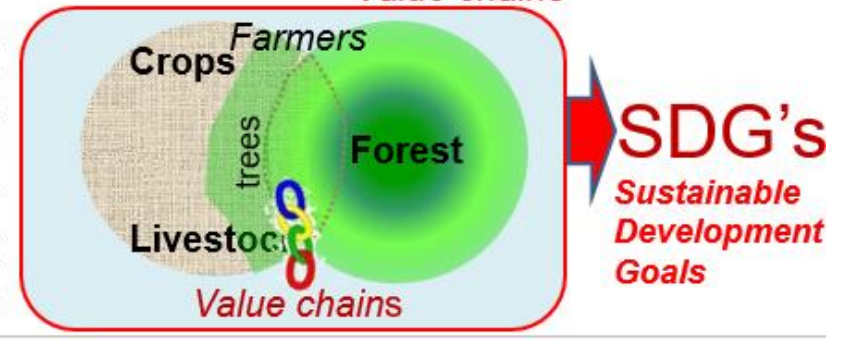

Figure 7. Three agroforestry concepts mapped on to the agriculture-forestry interface (van Noordwijk, 2014) 


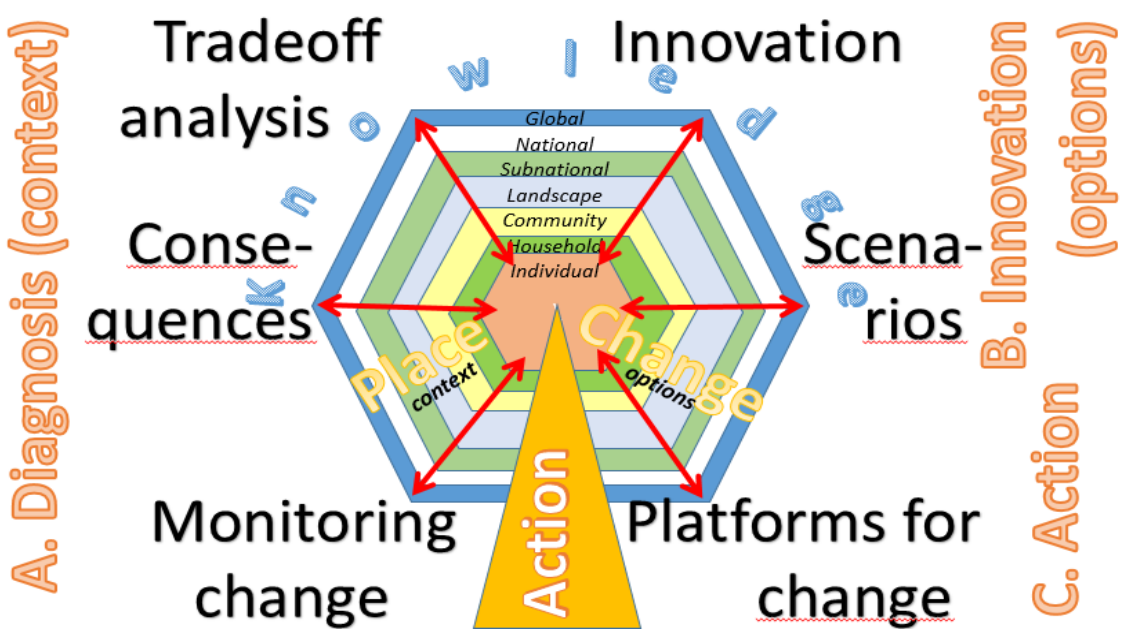

Figure 8. Modern version of the multiple learning loops of Figure 2 as a continuous cycle that links knowledge with action across scales, on the basis of six essential skills

\section{Proposed new definition}

Building on this nearly 40 years of use of the term agroforestry and various previous analyses (Nair 1998; Somarriba 1992; Leakey 1996) we here propose a new overarching definition that does justice to the various system scales, and that as a definition meets the basic targets of describing what it is and clarifying what is not included, while avoiding normative statements of what it should/could be. We propose ${ }^{3}$ :

Agroforestry, a contraction of the terms agriculture and forestry, is land use that combines aspects of both, including the agricultural use of trees. This includes trees on farms and in agricultural landscapes, farming in forests and at forest margins and tree-crop production, including cocoa, coffee, rubber and oilpalm. It includes interactions between agriculture and forestry as policy domains. Interactions between trees and other components of agriculture may be important at a range of scales: in fields (where trees and crops are grown together), on farms (where trees may provide fodder for livestock, fuel, food, shelter or income from products including timber) and landscapes (where agricultural and forest land uses combine in determining the provision of ecosystem services). At national and global scales, forestry and agriculture interact ecologically and through policies relating to land use and trade and are important with respect to climate change and other environmental concerns. Agroforestry embraces an agroecological approach emphasising multifunctionality and the management of complex systems and polycultures rather than focusing exclusively on monoculture. We use the word 'tree' inclusively, to refer to trees and shrubs, all woody perennials, palms and bamboo. We also use the word 'agriculture', inclusively, to refer to a human activity, carried out primarily to produce food, fibre and fuel, as well as many other materials, by the deliberate and controlled use of plants and animals. We understand pastoralists and pastoralism to be part of farmers and agriculture in this context. Further terms are explained in the glossary.

\footnotetext{
${ }^{3}$ Other options are: A) "Agroforestry is the combination of agriculture and forestry, including..." or B)

"Agroforestry is the combination of agriculture and trees, including..."
} 
In considering multiple variations on the wording, we used as criteria:

1. Clarity on what is and what is not, allowing data on extent, increase/decrease and correlations with other measurable to proceed (Table 1; as the intersection of "tree cover" and "agricultural lands" did in the Zomer et al (2016) analysis),

2. Be part of a network of terms that have operational meaning (while it is unavoidable that words are used that themselves need to be defined),

3. Avoiding circularity by not using the definiendum in the definiens (as for example the "forest" definition of Kyoto did by using the word "forest"),

4. Have a clear relationship with existing global and national data,

5. Not relying on "intentions" as part of the definition (as the FAO definitions do that classify rubber either as forest or as agricultural species depending on the intentions of the planter, with wood production or latex tapping as primary intent - this cannot be readily assessed in practice),

6. Be short, simple and memorable,

7. Be bold and ambitious,

8. Be inclusive of how the term has been used and understood before,

Table 1. Articulations of the basic agroforestry definition at multiple scales, and the contrasts with non-agroforestry it suggests to be open for empirical research (* see glossary)

\begin{tabular}{|c|c|c|}
\hline \multicolumn{2}{|r|}{$\begin{array}{l}\text { This definition embraces previous concepts and } \\
\text { definitions that have focused on: }\end{array}$} & \multirow{2}{*}{$\begin{array}{l}\text { What is not part of agroforestry and can be } \\
\text { used as basis for comparisons: } \\
\text { Evolutionary history of tree biology, ecology and } \\
\text { vegetation zones in pre-human systems; selection } \\
\text { of trees for single-purpose monocultures in } \\
\text { plantation forestry and horticulture, }\end{array}$} \\
\hline & $\begin{array}{l}\text { Trees* on farm }^{*} \text { (or trees outside forest) and the } \\
\text { opportunities for further in situ* tree } \\
\text { domestication*, }\end{array}$ & \\
\hline Ila. & $\begin{array}{l}\text { Biophysical interactions based on resource } \\
\text { capture and resource dynamics between trees } \\
\text { and other farm components at plot to farm scale } \\
\text { in spatial }{ }^{*} \text { and/or temporal }\left.\right|^{*} \text { ly defined integrative } \\
\text { agroforestry practices, }\end{array}$ & $\begin{array}{l}\text { Spatially and temporally segregate }{ }^{*} \text { production } \\
\text { ecology (resource capture, yield formation) of } \\
\text { trees }^{*} \text {, other forest products }{ }^{*} \text { crops }{ }^{*} \text { and livestock } \\
\text { without interactions between components with at } \\
\text { least some trees, and managed by farmers }\end{array}$ \\
\hline llb. & $\begin{array}{l}\text { Social }{ }^{*} \text {, and economic }{ }^{*} \text { interactions between trees } \\
\text { and other farm components at the 'farming } \\
\text { systems' and local knowledge level, often gender } \\
\text { differentiated within and between households }\end{array}$ & $\begin{array}{l}\text { Farming systems }{ }^{*} \text { and farm economics not } \\
\text { involving trees }\end{array}$ \\
\hline III. & $\begin{array}{l}\text { Landscape* level interactions and diversity }{ }^{*} \text {, often } \\
\text { combined with concepts of ecological } \\
\text { succession }^{*} \text {, maturity* and change over time as } \\
\text { well as ecosystem services*, in socio-ecological } \\
\text { systems }^{*} \text {, }\end{array}$ & $\begin{array}{l}\text { Agricultural landscapes without trees, and large } \\
\text { forest areas not involving farmers }\end{array}$ \\
\hline IV. & $\begin{array}{l}\text { Integrated land use }{ }^{*} \text { policies }{ }^{*} \text { that bridge the } \\
\text { institution*al divides between agriculture }{ }^{*} \text { and } \\
\text { forestry }^{*} \text {, in connection with value chain*s, } \\
\text { watershed management }^{\star} \text {, land tenure }{ }^{*} \text {, climate } \\
\text { change }^{*} \text {, biodiversity conservation* and } \\
\text { sustainable development }^{*}\end{array}$ & $\begin{array}{l}\text { Separately developed policies for agriculture, } \\
\text { livestock and forestry, and multisectoral }{ }^{*} \text { policies } \\
\text { that don't acknowledge the various gradual } \\
\text { transitions, often not clearly handled in operational } \\
\text { definitions }\end{array}$ \\
\hline
\end{tabular}


9. Have direct equivalents in major international languages,

10. Have a chance of being accepted by the wider community.

Others have used additional criteria, such as:

11. Avoiding words that may have negative associations, while creating a positive association and sense of purpose (as the Leakey (1996) definition did),

12. Include positive adjectives "important", "deliberate" or "purposeful".

Our choice of "the practice and science" is deliberate, where the "science and practice" sequence is more commonly used. With 10,000 years of agroforestry practice and 40 years of agroforestry science, however, we believe a more modest position of the term science is appropriate.

The interface and interactions can be understood in reference to a Venn diagram (Figure 7), with earlier definitions referring to specific practices on then $\mathrm{A}-\mathrm{F}$ intersection, or the intersection as a whole. The new definition refers to the union. The interactions are understood in different ways at different scale levels: trees entering farms, farmers entering forests, agriculture as driver of forest change, forests and its ecosystem services as precondition for agriculture, joint relations with land, labour, markets, knowledge and human wellbeing.

\section{Central hypotheses}

Hypotheses are most useful in the scientific process if they on one hand are inspiring and meaningful (if further supported by evidence after critical scrutiny), but are not truisms or framed in such a flexible way that no counterevidence could lead to their rejection. Hypotheses that meet these criteria have over time been framed at multiple levels, helping evolve agroforestry concepts, within and across recognized scientific disciplines. These include:

I. Tree properties (traits) and targets for phenotypic (e.g. in grafting) and genotypic selection in relation to growth and functioning, expanding portfolios,

II. Tree-Soil-Crop interactions in resource capture and efficiency, and long-term effects on soil conditions, with validated relations becoming part of synthetic models,

III. Agroforestry practices as labour-efficient means of production, farmer decision criteria,

IV. Multifunctionality of land use and associated tradeoffs between land use categories in the forest - open field agriculture continuum,

V. Theories of place: effective typologies of system properties, forest/tree transition,

VI. Theories of change at farm level, relating to profitability-driven AF adoption,

VII. Theories of change at landscape level, negotiating multifunctionality, buffer, risk,

VIII. Theories of induced change: participatory technology development, gender,

IX. Theories of induced change: negotiation support, conflict resolution, policy reform

$X$. Theories of induced change: effective boundary work, linking knowledge with action 
As important as such more specific hypotheses are for stimulating empirical work, we propose three candidates as "Central agroforestry hypotheses", one each in the three aspects of research: theories of place, change and induced change.

\section{Theory-of-place hypothesis}

In degradation and restoration phases, spatial and temporal configurations of forests and trees on farms in landscape mosaics at various scales (landscape, watershed, farm, plot) strongly interact with social and ecological context to affect how human population density and development options generate different land productivity and ecosystem services outcomes. Typologies of contexts that are to be the basis of effective scaling out need to take these aspects into account.

- Examples of possible counterevidence: 1) total forest/tree cover dominates and spatial configuration is of minor importance for the functions mentioned; 2) similarity in terms of human population density and tree cover typologies does not form a good basis for predicting subsequent change trajectories (either because nothing does and it's all idiosyncratic, or other predictors are shown to be stronger) 3) specific configurations found to be widely adapted irrespective of local conditions

- Slogan version: "Option by context interactions dominate"

- Formal tests: If $\mathrm{P}_{\mathrm{ij}}$ is the performance of option (configurations of trees in a landscape niche with management practices) $\mathrm{i}$ in context $\mathrm{j}$ and $\mathrm{P}_{\mathrm{ij}}=\mathrm{O}_{\mathrm{i}}+\mathrm{C}_{\mathrm{j}}+\mathrm{OC}_{\mathrm{ij}}$ Then: The variance of OC is much larger than the variance of $\mathrm{O}$ across a range of credible options and contexts within a domain ( add something on scales - eg domains that vary at at least 2 scales above that at which $\mathrm{C}$ are defined.

\section{Theory-of-change hypothesis}

Quantitative and qualitative declines in forest and tree cover along forest-rural-urban transitions in response to multi-scale drivers implies that there is scope for at least 100 million people for substantive increases in income, food and nutrition security and resilience in the face of climate change, through more inclusive and gender equitable access to and better utilization and management of agroforestry.

- Examples of possible counterevidence: 1) the number of people affected by the stated problems is, on further analysis, found to be significantly less than the 100 million people mentioned; 2) inclusive and gender equitable access is shown to be a minor factor compared to other factors (X, Y or Z) in achieving success; 3 ) there is no credible pathway to have these solutions be used, even if they are shown to be effective.

- Slogan version "Agroforestry can make a difference to lives"

- Formal tests If $\mathrm{P}_{\mathrm{ijt}}$ is the performance of any relevant indicator currently, it can be expected to be $\mathrm{P}_{\mathrm{ijc}}$ on the basis of currently active processes and their feedback effects in models validated in backcasting past change; agroforestry related change is a significant part of $\mathrm{P}_{\mathrm{ijc}}$ $\mathrm{P}_{\mathrm{ijt}}$. 


\section{Theory of induced change hypothesis}

Public and private governance and institutional arrangements can be transformed and aligned to a dynamic and evidence based decision learning cycle on agro-plus-forestry to create the necessary enabling environment for effective land use that supports achieving the Sustainable Development Goals (SDGs).

- Examples of possible counterevidence: 1) tree cover change and agroforestry adoption are not as important for the totality of SDG's, e.g. in comparison across countries where differential SDG achievements do not align with changes in agroforestry; 2) one-off decisions rather than continuous learning cycles are shown to be key to success; 3) we may be unable to transform governance and institutional arrangements, or, even if we can change policies, the changes may not be implemented. 4) institutional arrangements are found to be ineffective in pushing individual decisions ( eg on tree planting and use) towards agroforestry.

- Slogan version "Agro-plus-forestry reform makes achieving SDGs possible"

- Formal tests If $\mathrm{P}_{\mathrm{ijc}}$ is the performance of any relevant indicator expected in a business-asusual scenario and $\mathrm{P}_{\mathrm{ijf}}$ under a future supposedly improved regime, then $\mathrm{P}_{\mathrm{ijf}}-\mathrm{P}_{\mathrm{ijc}}$ can be large enough across domains of I to justify investments needed for scenatio $f$ rather than $k$.

\section{Ten key questions}

There have been various efforts to articulate the top 100 questions of importance to the future of global agriculture (Pretty et al 2010) and top twenty questions in landscapes and forestry ${ }^{4}$. Across the three types of theory, a use-oriented agroforestry science may have to find answers to the following ten questions:

A. Characterization, diagnosis: theory of place (ToP)

1. Land use options (what?): Terminology for gradients, practices and systems, with thresholds and points of reference for legends, maps and pattern recognition.

2. Contexts (who? where?): Social, ecological, geographical, economic dimensions of theories of place (ToP) that allow similarity typologies (and representativeness) to be assessed and experiments to be meaningfully stratified.

3. Choices (why?): Current (status quo) choices between and within land use categories, reflecting objectives, perceived issues, inferred priorities, managed tradeoffs.

B. Systems analysis and theories of change (ToC)

4. Production ecology and economics: functional traits, architecture, potential vs actual yields, yield gap analysis, Land Equivalent Ratios, Net Present Values, returns to labour, cashflow after investment, water balance, nutrient use efficiencies, timeaveraged $\mathrm{C}$ stock.

\footnotetext{
${ }^{4} \mathrm{http} / / /$ www.cifor.org/corporate-news/results-top-20-questions-forestry-landscapes/
} 
5. Process-level consequences, interactions: Landscape configuration as basis of lateral flows of water, nutrients, soil, fire, biota (incl. pollinators, pest $\&$ disease agents \& controls), climate, people (migration), economic multipliers and value chains.

6. System synthesis of feedbacks for scenario analysis: Farm-level management options in context, bioeconomic models, agent-based models linked to landscape dynamics, ecosystem services, links between local practice and global processes

C. Theories of induced change (ToIC)

7. Issue cycles (so what?, who cares?): response options (regulation, incentives, identity), political economy, rights-based approaches, sovereignty \& responsibility, climate change, globalization.

8. Nudge \& place-based governance: Land use \& low-emission development planning, prospecting agent-level response, SDG and actor synergy opportunities.

9. Coinvest: Value chain theories of change, Public-Private-Profit-Partnerships in responsible and fair trade and green growth, risk \& benefit sharing.

D. Sustainagility, learning and youth:

10. Continued change: resource base for continued change at the gene, organism, production system, learning landscape and social systems level, linking knowledge with action and values.

\section{Discussion: Conceptual diversity and institutional sustainagility}

The last of the ten question helps to focus on continued change, beyond the issues that are currently seen as being the most important. Agroforestry concepts continue to evolve within and beyond current definitions. The first generation of agroforestry definitions focused on specific practices that involve trees, crops and/or livestock and that are managed to secure that net interactions between components are positive. The second generation of agroforestry definitions shifted focus from the field and farm to the landscape scale and to all interactions between trees and farmed land, as well as between farmers and forest. The third generation address the national and global scale policy connections. Can there be anything beyond? Not in physical scale (it is unlikely that the moon, other planets or solar system will prove to be a fertile ground for agroforestry research anytime soon), but of course there may be new ways of analysing and advancing the concepts. 
Box 5. Credibility, Salience and Legitimacy as hallmarks of usable knowledge

Analysis of the conditions under which "new" knowledge is used in decisions and actions has consistently identified three characteristics that need to come together:

Credibility: Is evidence based on sound methods? Is it aligned with known mechanisms and processes?

Salience: Is there an action perspective? Can anything be done about it? Can it be used? Are consequences of possible actions understood?

Legitimacy: Can we trust the sources of information? Are they aligned with our values and interests?

If credibility would be the dominant criterion, as sometimes it is, it does not matter who is the source of information and how it is communicated ("these are the facts, whether you like it or not"). Domains of knowledge where credibility is the primary criterion have often been called "basic science". Curiosity on how things work is its primary driver. Applicability of science requires salience and action perspectives, and often requires understanding of interactions between the "new" knowledge and what already exists elsewhere, often derived from other disciplines. Engineering, whether technical or social, is its mindset to make things work. In most daily life situations, however, the legitimacy of what is claimed to be knowledge and information is a major issue. We live in a world of distrust, where commercial and political interests in making us believe statements and making us choose to buy products and services or vote for candidates and parties prevail. We tend to distinguish between "in-group" and "out-group" sources of information, with legitimacy confined to what comes to us via in-group channels. Historically the emergence of "science" that was not under the direct influence of those in power has been a remarkable phenomenon. It required access to finance for public goods, protected from short-term and private interests. It did so by emphasizing the credibility dimension. The cost of separating science from immediate and direct interests, however, was that a communication gap was created that required active "boundary work" to cross. In that boundary work the action perspectives of salience became inevitably intertwined with issues of legitimacy. In the international bodies that try to assess the overwhelming amounts of literature and claims on issues such as climate change, food security, biodiversity and ecosystem services, the "representativeness" of panel members is key to their chances to influence public understanding and decisions.

In furthering the understanding of agroforestry and the positive use of knowledge about trees on farms, in landscapes and influencing lives and livelihoods of people, the roles of credibility, salience and legitimacy (Box 5) need to be understood. Having solid evidence based on methods that are replicable and that have been scrutinized for hidden assumptions and bias is key. Clarity of terms, definitions and testable hypotheses, progressing towards robust synthetic theories is crucial. But equally important is that the research questions address the likely concerns of those who are potentially using the knowledge for their decisions and actions, and that they have benefitted from feedback in early stages to identify gaps and missing elements. Salience of research depends on a good understanding of its potential clients, but should avoid "political correctness". Most funding of research these days depends on convincing investors that there will be returns to their investment; and 
this easily leads to overclaiming, confirmation bias, selective reporting and a slippery slope that ends up with scientific fraud. Private benefits to the researcher of misrepresenting or "constructing" evidence to meet expectations raised may easily outweigh the costs and consequences of being honest about findings and not having contracts renewed as a consequence. Salience as dominant criterion at funding level may thus make it harder to maintain standards of credibility. Beyond that, however, are issues of legitimacy. Unfortunately there still is a substantial gap between the institutions and guardians of "forest" and local communities living in and using landscapes in which these forests have been carved out at some point in history. Foresters distrust local people and see farmers and their livestock as a threat. Farmers see foresters as policemen protecting external interests. Where thirdparadigm agroforestry is targeting a way of transcending these conflicts of the past, it requires full appreciation of the legitimacy dimension of research. It isn't just about evidence and its transparency (although open data sources and publications not protected by paywalls help). It isn't just about potentially policy relevant evidence (although early scrutiny of questions and research plans help). It is about the legitimacy of the way the evidence has been compiled, digested and communicated.

Our quick review of the history of agroforestry research suggests that at any point in time there was diversity in concepts that contributed, through routes that might have been beyond what current managers understood, to the further development. The D\&D work in the early 1980's was ahead of its time on adaptive learning cycles and participatory research, but had a hard time appreciating the relevance and results of the emerging tree-soil-crop interactions work. D\&D had in its practical application converged on recommending hedgerow intercropping as a near universal solution to almost any problem encountered, and the evidence that this didn't quite work the way envisioned was not easily accepted. The participatory line of research received fresh impetus in the AHI days, but this program competed for management attention with ASB that had stronger roots in "hard science" and silver-bullets-technology ideas. Of course, any of the above perspective can be contested and it will need a further analysis by those a little further from the coal face to do justice to this all.

The first macroeconomic model was published in 1936 by the physicist-turned-economist Jan Tinbergen, who became winner of the first Nobel price in economics when this was established in 1969. The model made ample use of existing statistical data in trying to understand the business cycles, with the various processes of positive and negative feedback that would get named as such in the late 1940's and that came to dominate system dynamics as this took shape in the 1950's. System dynamic theory increased our understanding of the nonlinear behaviour of complex systems over time using stocks, flows, internal feedback loops, and time delays. A major gap in these evidence-based models, however, was that they essentially extrapolated from historical patterns of resource use and could not, because of the way they were conceived, deal with innovation. A classical debate in this regards is the Malthus-versus-Boserup contrast. Boserup's fieldwork in W Africa in the 1960's challenged the pessimism of the Malthus theory that exponential population growth will crash as resources can only grow linearly (if at all...). Boserup (1981) became known for the optimistic perspective that technological change will be triggered as societal response to resource depletion issues and can help to avoid the primary Malthus collapse scenario. Indeed studies of induced intensification in Bangladesh (Turner and Ali 1996) and Kenya (Tiffen and Mortimer, 1994) supported the view that new technology arises when and where needed. Demont et al (2007) also concluded from fieldwork in northern Cote d'Ivoire that Boserupian innovation had through 
mechanisation and intensification, been largely able to compensate for the Malthusian repercussions of increasing population pressure. However, in a first stage demographic pressure had led to migration, a Malthusian population control mechanism, rather than Boserupian mechanisms of induced innovation, which started after a critical population density had been attained. The Boserup hypothesis was broadened by Hayami and Ruttan (1985) and Ruttan (1997) to a theory of induced innovation. Human inventiveness will rise to the challenge once the incentives to use existing resources more efficiently or find alternative pathways replacing them, are high enough.

It is still a challenge for theories of change to include the process and spread of innovation. Where endogenously induced innovation is incorporated into theories of change, along with the ability of socio-ecological systems to respond to and benefit from exogenous innovation, there may be less need for exogenously induced change in the forms used by "development support" efforts of the past decades. Most theories of induced change focus on a specific target of innovation that can be supported externally and traced on its way to societal impact. However, it remains a challenge to argue how this goes beyond the "bringing birds into a classroom, lecture them about flight, and claim they now learned to fly" story of Taleb (2012). Unleashing societal's ability to innovate has been the ultimate dream of development work for the past decades, even though achieving the goal might be against the vested interest of the sector. However, the resource base for future innovation will essentially be resources that are currently underused and that as yet have survived the pressure to eliminate them as efforts to maintain them are considered to be inefficient. Jackson et al (2010) contrasted the time scales of efficiency (focussed on what pays now) and persistence (focussed on essentials for current ways of life) to those of sustained agility (resource base for future change and human ability to think beyond current boxes). The authors argued that within-landscape agrobiodiversity, as supported in agroforestry practices, can be an important basis for sustained agility or sustainagility.

As discussed by Scherr and Hazell (1994), current trends in demography, agricultural production and rural environment in the developing countries suggest that so-called "marginal lands" must play a larger and probably growing role in food supply and economic development for the foreseeable future. Public policy towards these lands needs to be revised. A key policy focus should be to strengthen incentives for local land users to not only maintain, but to improve the natural resource base for food and fiber supply. Such "land-improving investments" are needed to reduce production and subsistence risks and permit more intensive use without degradation.

In line with the Hayami and Ruttan (1985) theory of induced innovation, one can expect under population and market pressure, an endogenous process of intensification, through land improvements, tenurial and institutional changes to re-order the landscape. But this process is not automatic. Factors influencing the pace and scale of land transformation include: farmer knowledge of degradation of the degrading resource; incentives for long-term investment; capacity to mobilize resources for land investment; level of economic returns to such investment; a nd factors affecting the formation and function of local groups to help mobilize resources and coordinate landscape-level change (Scherr and Hazell 1994). Existing policies often work to constrain, rather than support, this process, with the institutional barriers between "forest" versus "agricultural lands" as element, along with the extraction of public forest rents from the sale of non-timber forest products, even if these are produced on farm, in forms of agroforestry. 
In the end it may be the sustained agility or sustainagility (Verchot et al 2007; Jackson et al 2010) that matters more than any specific solution for current problems at any of our nested scales. Sustainagility analysis suggests that sustainability at any system level can derive from two sides: sustainability of its current subsystems, and the options to change subsystems and the interactions between them. "New" subsystems may have persisted within the wider system under consideration (potentially as part of a deliberate diversity maintenance strategy), or be obtained from elsewhere. The costs of obtaining new subsystems from outside has in the past been subsidized to the degree that maintaining internal diversity may have seemed to be a waste of resources. While agroforestry researchers are generally inclined to support the maintenance of diversity and adaptive learning, it will be important to apply this also to the diversity of concepts, ways of knowing, learning styles and research methods within our community.

Recent work suggests new roles of trees and forests in the coupling of atmospheric and terrestrial parts of the hydrological cycle. Where most existing studies and predictions of water shortage take rainfall as an exogenous variable, beyond human control, the understanding of "rainbow water" (van Noordwijk et al 2014), ecological rainfall infrastructure and biological rainfall generation (van Noordwijk et al 2015) adds a new dimension to the discourse. Recently Syktus and McAlpine (2016) explored the capacity of regional-scale restoration of marginal agricultural lands to savanna woodlands in Australia to reduce warming and drying. They showed that restoration triggers a positive feedback loop between the land surface and the atmosphere, characterised by increased evaporative fraction, eddy dissipation and turbulent mixing in the boundary-layer resulting in enhanced cloud formation and precipitation over the restored regions. "The increased evapotranspiration results from the capacity of deep-rooted woody vegetation to access soil moisture. As a consequence, the increase in precipitation provides additional moisture to soil and trees, thus reinforcing the positive feedback. For the restored regions (representing 20\% of Australia), the averaged surface temperature increase was $3.2{ }^{\circ} \mathrm{C}$ which is $0.82{ }^{\circ} \mathrm{C}$ cooler compared to agricultural landscapes. Further, there was reduction of $12 \%$ in the summer drying of the near-surface soil for the restored regions." The opportunity to achieve similar effects with tree cover in agricultural lands opens a new perspective on what climate smart landscapes can achieve.

\section{Conclusion/recommendations}

We propose a new definition of agroforestry that meets the basic criteria of clarity what the term means, what is "in" and what is "out", so that empirical studies can make valid comparisons and hypotheses about properties of agroforestry can be tested. We propose a defintion that can be readily applied at all scales from trees to global resource governance. We also propose that the three concepts of agroforestry identified so far are seen as synergistic and benefitting from the others, rather than as paradigms with new ones replacing the old. As current interest in the further use of agroforestry for achieving sustainable development goals requires greater precision on which options achieve what in which contexts, distinctions between theories of place (contexts), theories of change (options, choices, feedbacks internal to the system under consideration) and theories oif induced change (likely response to externally initiated interventions) are disnguished. For each an overarching agroforestry hypothesis is outlined as basis for further discussions. 


\section{Appendix. FTA Phase II plans as communicated through 28 Hypotheses, 15 Assumptions and 68 Key research questions}

The following hypotheses, assumptions and key questions (often alternative ways of formulating similar ideas) were extracted from the proposal for a CGIAR Research Program on Forests, trees and Agroforestry, in the version resubmitted on 31 July 2016 by CIFOR on behalf of CIFOR, ICRAF, Bioversity International, CIAT, CATIE, CIRAD, Tropenbos International and INBAR. FT\&A refers to forests, trees and agroforestry in their real-world manifestations, FTA to the specific research program proposed for the period 2017-2023.

FTA level hypotheses:

I. Governance hypothesis: Public and private governance and institutional arrangements must be transformed and aligned to create the necessary enabling environment allowing FT\&A systems to fully contribute to achieving the SDGs

II. Livelihood hypothesis: There is scope for major increases in income, food and nutrition security and resilience for at least 100 million people in the face of climate change, through more inclusive and gender equitable access to and better utilization and management of FT\&A systems

III. Trade-offs hypothesis: To optimize benefits among diverse stakeholders at scales from the farm to the globe requires understanding and actively managing tradeoffs among the production of food, fiber, energy, water, other ecosystem services and the maintenance of biodiversity from forests and trees in landscapes.

FTA-Gender Hypotheses:

1. Policies are an integral part of the contextual conditions that affect the capacity of different actors to participate and capture benefits from the management of forests and tree-based production landscapes. Improved synergies among sectorial policies in the target countries can create incentives for women to get involved and benefit from forestry and agroforestry interventions

2. (i) The active participation of women and marginalized groups in forest and NRM is mediated by the interaction of gender-based constraints and interests. Appropriate mechanisms can promote greater gender equity and social inclusion in forest governance institutions. (ii) Women's participation and decision-making can lead to more sustainable local tree management practices and improved livelihood outcomes

3. (i) Climate change policies and interventions that address gender inequalities can promote equitable benefit distribution, harness producers' innovative capacities and create long-term, positive mitigation and adaptation effects. (ii) Policies can anticipate risks and reverse harmful inequalities when they are informed by understanding of socially differentiated interests and needs, and when they incorporate mechanisms for meaningful participation of marginalized groups in decision-making processes in their development and implementation 
4. (i) Gender norms structure the extent and nature of women and men's participation in FTA value chains. (ii) Gender-blind policy interventions and business models can exacerbate gender inequalities. (iii) Gender-responsive interventions and business models improve gender equality and may offer synergies for enhancing their environmental and economic sustainability

5. In the highly globalized world that forested landscapes are a part of, women are increasingly migrants, left behind, and/or both. These are likely to have different and contrasting consequences for women's empowerment, work burden and social capital.

6. Extension and delivery approaches that seek to transform gender roles and promote more gender-equitable relationships between men and women will achieve more equitable participation in household agricultural decision-making and improve uptake of forestry and agroforestry technologies

Flagship 1: Tree genetic resources (TGR) to bridge production gaps and promote resilience

1. Genetic diversity can be monitored by cost-effective development and application of adequate tools, with methods for safeguarding being adjustable in response to suitable indicators; an optimal combination of TGR safeguarding measures can be identified in specific ecological, geographical and societal contexts, considering the positive and negative interactions between the measures applied; regulatory frameworks and incentive schemes in favor of integrated TGR safeguarding can be designed

2. It is possible to apply a range of context-specific domestication approaches and to determine their relative cost-effectiveness for different production systems and landscapes; appropriate domestication approaches are available to contribute effectively to farm- and landscape-level resilience through the adequate management and deployment of TGR, maintaining or enhancing diversity; the protection of small farmers' intellectual property enhances the local development of tree 'cultivars' of documented quality, and facilitates their diffusion through formal and informal channels (facilitated by CoA 1.3)

3. Context-specific characterization of planting material delivery systems can be undertaken for trees to allow for an adequate assessment of their efficiency; among the wealth of differently organized input supply systems that are currently applied it is possible to identify those that work best in a given context; it is possible to produce context- and tree biology-specific recommendations for tree planting material delivery systems, enabling high potential for increasing productivity and farm- and landscape-level resilience making impact at scale for smallholders through improved management and marketing of trees and their products requires addressing the fine-scale variation in context that conditions suitability of options

Flagship 2: Livelihood Systems

1. Smallholder income can be increased and made more equitable by better connecting smallholders to markets and developing markets for key tree and forest products

2. Appropriate incorporation and management of companion trees in cocoa and coffee production systems, alongside appropriate fertilizer and pest control, can increase and sustain productivity of existing stands and buffer against climate change; (ii) rubber and oil palm production systems can be made more sustainable through intercropping; and (iii) 
smallholders can derive higher income from product sales through improved certification schemes and by exploiting specialist market niches

3. The establishment and better management of tree cover in crop fields and farmsteads can increase and sustain soil health and crop yields while contributing to system intensification through provision of fodder and fuelwood on farms

4. Establishment and better management of tree cover on pastures can contribute simultaneously to higher livestock productivity, animal welfare and biodiversity conservation as well as restoring degraded rangelands and avoiding future degradation

Flagship 3: Sustainable global value chains and investments for supporting forest conservation and equitable development

1. Private sector sustainability standards, in conjunction with supportive public policy, will foster improved management and business practices with enhanced socio-environmental performance

2. Downstream value chain actors adopting business models that integrate smallholders and SMEs will contribute to achieving inclusive development and sustainability objectives

3. Linking ESG integration into FSP operations while improving access to smallholder and SME finance may trigger wider uptake of sustainable supply and inclusive business models

Flagship 4: Landscape dynamics, productivity and resilience

1. Forest and tree cover transition as process interacts with social, political, economic and ecological factors in ways that allow the recognition of similarity domains, supporting outand up- scaling of theories of change where an integrated landscape approach is used

2. Spatial and temporal configurations of forests and trees on farms in landscape mosaics at various scales (landscape, watershed, farm, plot) matter for the way ecosystem services change with scale; understanding of the scaling rules can be used in planning land use for multiple ecosystem services

3. Landscape mosaics with partial forest cover and agroforestry support nutritional diversity and human health beyond their current weak recognition in policies aimed at increasing food security

4. Contextualized generic theories of change at the landscape scale provide an "efficiently fair" middle ground in progress towards sustainable development goals

Flagship 5: Climate Change

1. Carbon-effective, cost-efficient and equitable emission reduction (mitigation) strategies and policies (Paris goals) can be attained involving FT\&A resources and combined with development objectives (SDGs) through broad, integrative, cross-sectoral approaches using a political economy lens.

2. Strategies, policies, institutions and practices can be developed to preserve and manage FT\&A resources for efficient and effective adaptation of people and landscapes to global environmental change and support joint mitigation-adaptation.

3. Renewable bioenergy from FT\&A can effectively and efficiently support energy sufficiency and equity and generate rural income in developing country sustainable landscapes. 
4. Methods to reliably and independently monitor and assess performance of mitigation and adaptation policy and practice can be developed, linking these to cost and benefit sharing.

Assumptions along the FTA pathway to impacts

1. Policy and decision-makers find FTA's knowledge and evidence credible and relevant. Absence of significant perverse incentives and/or power vested interests in maintaining the status quo.

2. Willingness of and incentives for targeted private sector actors to do business differently.

3. Positive national research systems \& line ministry receptivity; pre-requisite capacity \& infrastructure exits that can be developed.

4. Targeting is inclusive and appropriate; extension system tailors innovations to differing contexts and groups. Smallholders find it worthwhile to invest in the complementary management practices \& livelihood options.

5. Adopted governance arrangement, mechanisms and tools are intrinsically effective AND properly implemented.

6. Scale and extent of FT\&A protection, enhancement and promotion is of sufficient scale to generate significant ESS.

7. Options to improve resilience and agro-ecosystem health are adopted and sufficiently efficacious in scaling context. Climatic and other shocks to which targeted farming systems are subjected are not exceptionally severe.

8. Food produced (or purchased with increased income) is of sufficient quantity and quality and is actually consumed. Additional income generated is significant and stable enough to bring smallholders out of poverty.

9. Partnerships built in Phase I will continue and increase their engagement; the entry points identified to influence policies and institutions will ensure uptake of research findings.

10. Evidence on the relationship between sustainable forest management and tree-based livelihood strategies and the empowerment of women and other vulnerable groups will influence the design/reform of policies, institutions and interventions

11. Improving awareness, capacities and more gender-balanced participation in forest and NRM, will help women's access and control over forest and tree-based resources and related income

12. Demonstrating the value of TGR for improved livelihoods, restoration and domestication supports safeguarding activities in collaboration with farmers and other stakeholders; more efficient tools and approaches to support TGR safeguarding, including through the sustainable extraction of products, can be devised from an understanding and description of model species and the contexts of systems; policies and legal instruments implemented to provide for ABS can be compatible with the characterization of germplasm that supports TGR safeguarding

13. A key factor that supports the integration of new tree crops in agricultural production systems is an increase in productivity and/or product quality; sufficient genetic diversity is present within tree species to realize large genetic gains (and hence production gains, once 
material is delivered to growers through CoA 1.3); communities have already or can obtain land and tenure rights that allow them to reap the benefits from improving their production systems through better quality tree planting material inputs; policies and legal instruments implemented to provide for ABS do not need to prevent access to TGR to support genetic improvement activities

14. Smallholders and other tree planters will demand higher-quality planting stock when its benefits have been demonstrated to them and/or when appropriate certification/traceability schemes are in place, increasing adoption and providing market opportunities for germplasm suppliers; better institutional organization of stakeholders involved in delivery can reduce transaction costs for farmers and other growers in obtaining suitable material; policies, legal instruments and certification schemes, implemented to provide for ABS, to protect breeders' and farmers' rights and to control planting material quality, provide a supportive environment for delivery and do not significantly increase transaction costs

15. Business models that productively integrate smallholders and SMEs offer win-win opportunities by increasing buyer access to raw materials while improving smallholder and SME access to profitable (global) markets and services that facilitate the uptake of more intensive and environmentally sustainable production practices.

Key research questions:

1. What are the effects of different sector policies in creating constraining or enabling environments for women's access to and control over forests, trees and other productive resources?

2. What types of institutional arrangements promote meaningful participation of men and women in decisions related to forest restoration and management? Under what conditions does such participation translate into more equitable benefit-sharing and sustainable NRM?

3. What are the structural causes of gender differentiated impacts of climate change, and what factors strengthen the voice, influence and entitlements of marginalized groups resulting from adaptation and mitigation policies and interventions?

4. What are the problems marginalized groups face in different FTA business models and value chains across different institutional, economic and cultural contexts? What types of strategies, institutional arrangements, interventions and safeguards should be used to improve gender responsiveness of FTA value chains and business models? How can potential synergies be amplified - and trade-offs mitigated - between the gender responsiveness and the environmental and economic sustainability of such business models?

5. What is the impact of gender differences in patterns of migration and mobility (male-led, women-led, mixed-gender) on women's voices and influence in forest governance? Which types of policies, institutional arrangements and interventions foster enabling environments for women and men to benefit from migration and multi-local livelihoods in forested landscapes?

6. What type of extension arrangements will improve the uptake and gender responsiveness of forestry and agroforestry technologies and planting materials and create opportunities for women's empowerment? 
7. Indicators and methods: What are the most cost-effective indicators and methods to determine the extent, trends/threats and value (current and option, for productivity and resilience) of TGR in natural and restored forest, farm and other settings, to identify the location and intensity of threats to valuable TGR and support the development and implementation of appropriate safeguarding partnerships and activities?

8. Safeguarding combinations: What are the minimum requirements and optimal combinations of safeguarding approaches for TGR, considering synergies and trade-offs between them in specific contexts, including in particular geographic regions, production systems, landscapes, and policy environments, and considering different users' needs, to support sustainable resource management?

9. Stakeholder engagement: How can stakeholders be convinced and supported (e.g. through payments for ecosystem services) to develop, implement and monitor cost-effective conservation plans and strategies for safeguarding TGR in different contexts (forest, farm, etc.), taking into consideration conservation status, trends and threats for target species, and local knowledge and experience?

10. Domestication approaches: What are appropriate, cost-effective domestication approaches for priority trees, and how can impacts in providing products and services be effectively assessed among possible domestication options, to maximize efficiency in bridging production gaps and in enhancing profitability?

11. Trade-offs in domestication: How can domestication approaches be developed and implemented that fully consider the trade-offs involved across the intensification gradient (polycultures-monocultures), and support higher levels of species and genetic variation in production landscapes, to strengthen their resilience?

12. Smallholder involvement: What are appropriate measures to put in place (e.g. the protection of intellectual property) to support the wider participation of smallholders and local communities in developing new and unique 'cultivars' of a wide range of tree species, that supports impact by out-scaling?

13. The baseline of delivery systems: what are the most effective ways to characterize, evaluate and monitor ultimate success of the current tree-planting-material delivery systems to smallholders and other growers, including of the sources, pathways, actors (collectors, producers, traders, other distributers, NGOs, government agencies, etc.) and policies involved, in order to provide a baseline from which to make improvements?

14. Appropriate delivery systems: what are the most cost-effective and equitable tree-plantingmaterial multiplication and delivery systems for smallholders and other growers, to supply high-quality, site-appropriate material, taking into account: the required scale and reach; the appropriate division of costs and benefits among stakeholders; the need to provide complementary options to buffer production risks; and the existing policy environment?

15. Information and regulation: what decision-support tools, policy measures and regulatory frameworks are required to allow growers to match and anticipate production requirements and restoration objectives with suitable, available tree-planting material, taking into consideration changes in climate, markets, social diversity, quality of natural regeneration and other important trends? 
16. How can we most efficiently, effectively and equitably co-develop design principles for matching options that improve the use of trees and forests by smallholders (comprising technologies, extension methods and market interventions, and policy and institutional instruments) to the fine-scale variation in the context of smallholder livelihood systems? This requires us to understand how contextual variables condition the suitability of options and to embed participatory action research within a systematic frame. How can scientific information be used to support negotiation among stakeholders, bridging farm to local landscape scales to manage the impacts of land-use change on ecosystem service provision? What are the political and institutional conditions that allow for household and smallholder success in terms of livelihood improvements, including ways to scale-up the results from interventions?

17. How can tree crops help to build critical livelihood assets (e.g. human, social, natural, physical and financial capital), and how do asset endowments and dynamics vary across and within households according to gender and age? How can access to and control over these assets by women and young people be improved?

18. How can barriers be removed to smallholders accessing markets for tree and forest products, allowing them to capture more of their value, especially for people who are socially or economically marginalized (including women and young people)? What types of products and markets are most suitable and what interventions are most cost effective to realize these outcomes? How can smallholders profitably produce and market quality timber on a small scale? How do different approaches to forest management impact smallholder livelihoods at the forest margin?

19. How can smallholder tree-crop commodity production systems be sustainably managed in the face of climate change, price volatility, declining yield and soil fertility following forest conversion, coupled with constraints on opening new forest areas, and those imposed by the dynamics of migration? What is required in terms of an enabling environment to switch from unsustainable monocultures to more diverse and resilient production practices?

20. What are the optimum levels of tree density and diversity in different contexts required to increase total productivity of smallholder livelihood systems while conferring resilience at farm and landscape scales? We also need to understand how to effectively promote the desired density and diversity, given a widespread history of removing trees from agricultural land, conflicts between grazing animals and tree regeneration and promoting of a few, largely exotic tree species on farms and in woodlots, rather than more diverse options. What is the relationship between tree cover (density and diversity) and soil health and where are there trade-offs and synergies between production goals and the provision of other ecosystem services?

21. What is the relationship between tree cover (density and diversity) and pasture and animal productivity and welfare in silvo-pastoral systems? Where are there trade-offs and synergies between production goals and the provision of other ecosystem services?

22. What political, institutional and social factors contribute to shape the adoption and implementation of public policies and private sustainability standards and commitments? 
23. How do private standards and commitments, in their interaction with public policy at different scales, influence the effectiveness and adoption rates of sustainable practices in value chains?

24. What are the public, private or hybrid arrangements that have the most potential for enhancing the adoption of sustainability practices and social inclusivity in the value chain?

25. What production and management practices are needed to simultaneously increase sustainable supply and social inclusion and equity (gender, intergenerational)?

26. What types of business models involving smallholders and SMEs can be identified and how economically viable, socially inclusive and environmentally sustainable are they?

27. What barriers to participation do women, youth and other marginalized groups face in different business models and value chains across different institutional and economic contexts?

28. What are the factors that explain the distribution of benefits across different types of business models and how can benefits be distributed more equitably among different stakeholders?

29. How can value chain service providers contribute to the development of more impactful and adaptive business models in different value chain configurations?

30. What governance and institutional arrangements could facilitate scaling of business models that better manage social, environment and economic objectives?

31. What are the incentives and constraints that shape the implementation of responsible investment and financing practices by FSPs under different institutional and economic conditions?

32. How do different types of FSPs integrate ESG into the design of their products and services (e.g. project finance, asset management, debt and equity capital markets) to attend different financial operations along value chains and what factors shape their ESG integration strategies?

33. What mechanisms could promote more widespread adoption of ESG criteria among different types of FSPs and improve the influence thereof on corporate social and environmental performance as well as including more supportive criteria to include smallholders?

34. What factors restrict the access of smallholders, including women and youth, and SMEs to financial products and services, and under what conditions could access and availability to these goods and services be enhanced to support inclusive and sustainable development objectives?

35. What institutional architecture(s) are needed to improve smallholder and SME access to affordable credit and what other complementary technical and market conditions have to be in place?

36. Who are the actors and stakeholders of the landscape, in a historical-political perspective on (claimed) rights, an economic perspective on livelihoods and value chains and a culturalsocial perspective on identity and aspirations? 
37. What land use systems are present where in the landscape and what are current patterns and intensities of change (tree cover, objectively observable aspects of forests, farms, other land uses) in space and time

38. Can observed changes be understood ('why?') on the basis of drivers that operate at larger scales, demography and economic policies?

39. What are the consequences of changes ('so what?' and 'who cares?') in quality, quantity and spatio-temporal configuration of forest and tree cover in landscapes for ecosystem functions that underpin the provision of usable goods and other ecosystem services (with specific attention to biodiversity and the full hydrological cycle e.g. effects on terrestrial recycling of rainfall, safe drinking water, water-sustainable agricultural intensification, and regulated water flows)

40. How are perceptions and preferences of ecosystem functions differentiated by gender, ambitions of young people and intergenerational aspects?

41. How can stakeholders of the (unintended) consequences of landscape change achieve leverage on the drivers of change, through a combination of rights-based approaches (incl. land use planning, tenurial reform), economic instruments (generic tax/subsidy, specific performance-based contracts) and motivational factors (addressing perceived 'fairness', 'environmental justice')?

42. How can existing 'green economy' planning tools for land use for multiple ecosystem services be improved, adapted and adopted more widely?

43. How does landscape multi-functionality contribute to human well being and healthy and diverse diets through the (local) availability of and access to improved tree food sources as well as wild foods (i.e. provisioning services part of the wider ecosystem services concept)?

44. How can local and external stakeholders concerned about consequences of 'business as usual' trajectories affect the generic drivers and/or community and household level incentives (including economic and socially constructed ones) and rights (including tenure) to nudge land-use decisions into a more desirable direction (including land-use plans for enhanced multi-functionality, economic incentives)? How can ecosystem services be restored most effectively within landscapes in terms of both defining the desired changes (restoration to forest or agroforest, use of ecosystem services-friendly agroforestry practices) and types of intervention (regulation, incentives, markets for ecosystem services)? Key sub-questions are the ways in which gender and intergenerational empowerment can be achieved.

45. 5.1.1. Comparative analysis of best, $3 \mathrm{E}+$ options for policies and practices for emission reduction in support of country-level development and implementation of NDCs (including REDD+18, NAMAs, SFM, and JMA) and international climate change policy-making, using FT\&A resources; and including analysis of ways to reduce complexity and $3 \mathrm{E}+$ goals in LEDS (e.g. governance of multi-level and multi-sectoral integration of local, national and regional climate change, restoration and development agendas)

46. 5.1.2. Research on policy and practice of forest restoration and on enhancing the forest carbon sink capacity (supporting the Bonn Challenge), e.g. in collaboration with the 2020 initiative 
47. 5.1.3. Research on the complex challenge of forest fire policies, with particular reference to Indonesia

48. 5.1.4. Research on the effectiveness and efficiency of results-based climate finance and incentive mechanisms, including through the Green Climate Fund, in affecting policy and behavioral change towards mitigation and adaptation outcomes

49. 5.1.5. Studies of the enabling policy architecture and public-private partnership mechanisms that can enhance performance of corporate zero-deforestation commitments and other mitigation initiatives, addressing standards and certification (with FP3)

50. 5.1.6. Support for evidence-based decision-making in NDC planning and implementation (e.g. in support of the Facilitative Dialogue set in the Paris Agreement) and develop policy learning from country-level to the international policy arena.

51. 5.2.1. Continued work on understanding the synergies/trade-offs between mitigation and adaptation in support of the Paris Agreement (link to CCAFS)

52. 5.2.2. Assessment of potential impacts of climate change on biodiversity, ecological functions and ecosystem services to assess risks and vulnerability of both people and forests, systematize experiences where FT\&A has strengthened local responses to climate change, equitably reducing risk and increasing resilience and to contributing analysis to the 'loss and damage' debate

53. 5.2.3. Identifying options to reduce climate-related risks, analyzing trade-offs, exploring adaptation economics, using and demonstrating ecosystem-based adaptation (EbA), developing adaptive capacity of social groups and exploring the interface to climate-smart agriculture (CSA)

54. 5.2.4. Comparison of policy mechanisms that strengthen local capacity to respond with EbAto expected climate change and variability (e.g. land-use planning, multi-stakeholder dialogues, encounters of knowledge), and their integration into national development and adaptation plans (NAP, NAPAs) across scales

55. 5.2.5. Development and testing of approaches to measure and monitor effectiveness and efficiency of EbA actions in reducing vulnerability and increasing resilience to inform national and international policies and priority setting. Setting apart unsuccessful, businessas-usual tree- and land-based interventions from successful EbA requires a toolset integrating vulnerability assessments of socioeconomic and ecological systems to increase resilience.

56. 5.2.6. Experimentation with and development of flexible, data-driven approaches that emphasize flexibility and heterogeneity as risk reduction strategies and feedback-based policy responses.

57. 5.3.1. Analysis of the current status of bioenergy types, including the relative benefits, disadvantages and the extent of their use in different regions

58. 5.3.2. Analysis of international and national drivers of bioenergy development to understand how markets and standards (e.g. EU Renewable Energy Directive) affect land allocation for bioenergy production 
59. 5.3.3. Assessments of potential of bioenergy production on degraded land using spatially explicit data about the area, type and extent of degradation, tree species' suitability, growth and yield at national and subnational level in Indonesia

60. 5.3.4. Analysis of the impact of bioenergy on social and environmental outcomes (e.g. health, poverty, migration, gender, biodiversity) to support equitable, sustainable energy generation

61. 5.3.5. Studies of demand and supply, costs, social and environmental impacts, carbon footprints and synergies/trade-offs with food production and variation by region, feedstock types and scale of bioenergy production

62. 5.3.6. Scenario development: Analysis of how bioenergy extraction links to landscape configuration, as people's practices of wood extraction depend on a landscape, but also shape it; assessment of how future energy developments may affect the role of biofuels, retaining flexibility to include new developments (e.g. lignocellulosic fuels) and investigate how they may benefit stakeholders.

63. 5.4.1. Determine reference levels: Research that supports the setting of country targets, baselines/reference levels/points of departure regarding FT\&A resources, carbon stocks and other ecosystem services for REDD+, NAMAs, INDCs and LEDS; develop criteria and tools to measure and contribute to private-sector assessment

64. 5.4.2. Basic research to understand carbon source/sink dynamics to improve regional and global models (link to SP1) and feed into IPCC processes aiming to implement the Paris Agreement

65. 5.4.3. Measuring non-carbon benefits (biodiversity, governance and livelihood outcomes, social equality, and informing the implementation of safeguarded information systems). Use of innovative methods, such as qualitative comparative analysis and quasi-experimental methods to identify causal change

66. 5.4.4. Impact assessment of REDD+ policy and practice, building on 8 years of comparative research and longitudinal datasets

67. 5.4.5. Identify and develop approaches to cost-efficient, transparent, reliable MMRV, including independent monitoring approaches. We specifically aim for more integrated landscape monitoring approaches(e.g. including climate modeling) to assess multifunctional performance (linked to 5.4.3.) building on existing methods and approaches, so that countries find support in their multiple monitoring needs under Paris (INDCs), SDGs and the like. Linking MMRV for forest- and agriculture-related mitigation should create important synergies for mitigation planning and implementation

68. 5.4.6. Coupled bio-economic modeling to understand emergent properties, complexity and conditions of landscape systems. Develop decision-making tools; e.g. landscape management for LEDS: models of future scenarios and climate/carbon outcomes under different land-use policies; spatial economic analyses to assess the cost and equity implications of policy mix options. 


\section{Glossary}

As it seems unavoidable that the definition of a term like agroforestry relies on terms that themselves have specific meaning in this context, that may not be non-ambiguously clear from the general use (as documented in dictionaries) of these words, we provide a tentative glossary here of the network of terms linked to our definition of "agroforestry". All words that are listed in the glossary are marked with *.

Agriculture*: Land use aimed at production of crops and livestock for human use; it includes extensive livestock systems known as pastoralism

Agroforestry practices*: Farming practices* that include trees

Agroforestry systems*: Farming systems* that include trees

Agro-plus-forestry policy*: Policy that bridges between agriculture and forestry as sectors, for example in terms of rules, taxes, subsidies, professional training, knowledge management and academic research

Annual*: Plant completing its lifecycle within a single year

Biodiversity: Diversity of biota, often considered at genetic and taxonomic, intra- and interspecific, levels

Biodiversity conservation*: Efforts to return rates of extinction at gene, species or higher taxonomic level to pre-human levels

Circular economy*: Economy based on recycling rather than unconnected value chains

Climate change*: Change of climate (average and variability of rainfall, temperature, wind, humidity, solar radiation in a 30-years window), in part due to human activity (anthropogenic climate change)

Crops*: Plants domesticated and grown for human use of their products (roots, stems, leaves, fruits, seeds, a.o.) (NB: if not growing on an intended location it can be regarded as a weed)

Deforestation*: Change from a forested to a non-forested state, which depending on forest definition, relates to both institutional and tree cover dimensions

Degradation*: Loss of functionality from the perspective of (specific) humans, usually based on change in land cover and ecosystem services

Degraded lands*: Lands that have lost functionality beyond what can be recovered by natural processes in a defined, policy relevant time frame

Development*: Emerging from previous constraints ('envelopes'), often creating new constraints at other scales (see sustainable development)

Diversity*: Variation in properties

Domestication*: Modifying the behavior and properties, and usually the genetic basis of such, of plants and animals to suit human needs

Economic*: Study of human decisions on scarce resources

Ecological*: Relating to all biota (including our species) interacting with planetary resources 
Ecological succession*: Process of change in vegetation, often based on increased presence and importance of (woody) perennials, starting from bare substrate (rock, soil, water)

Ecological maturity*: Endpoint of ecological succession

Ecosystem services*: Benefits humans derive from functioning ecosystems services based on the products they can derive from its ecological function and self-regeneration, the buffering and regulating effects on climate, flows of water and organisms, and the cultural, spiritual, historical or religious identity people can derive from functioning ecosystems

Environmental services*: Ecosystem services with exclusion of the provisioning of marketable products

Farm*: Enterprise using land for agriculture, livestock management and/or fisheries

Farmers*: Those making a relevant part of their living from practicing agriculture (including livestock management, pastoralism and fisheries)

Farming practices*: Efforts to grow, modify the resource base for, and manage crops, livestock and/or fish to meet defined targets

Farming systems*: Systems* that combine and manage interactions between farming practices, household resources of land, labour, knowledge and access to credit and markets to meet defined targets

Forest*: Land with trees under specified management authority; common definitions combine biophysical aspects of tree cover (minimum spatial tree cover over defined percentage of time at defined measurement scale) with institutional aspects (excluding trees that are considered to be agricultural)

Forestry*: Institutions involved in forests (often interpreted in juxtaposition to agricultural)

Forest products*: Any product, timber or otherwise, derived from trees or other life form in forests (incl. medicinals, bushmeat), but excluding mineral resources not related to forest biota

Forest services*: Ecosystem services derived from forests

Gender*: Social distinctions between humans related to their biological sex and/or perceived identity

Glocal*: contraction of global + Local

Greenhouse gasses (GHG): Gasses that modify the radiation balance of the atmosphere through modifying transmission, reflection and retention of energy derived from solar radiation

Governance*: Efforts to modify human actions and activity in order to meet goals set at higher system levels, often based on a combination of rules (and their enforcement), economic incentives, and motivation or re-enforced identity (intrinsic norms of behaviour in social groups)

Horticulture*: Forms of agriculture focused on gardens to derive vegetables and/or fruits Human capital*: All the knowledge, talents, skills, abilities, experience, intelligence, training, judgment, and wisdom possessed individually and collectively by individuals in a population In situ*: In or close to the location of intended use 
Institutions*: Mechanisms and rules of the game of social interactions, with variable degrees of formal and legal basis

Land cover*: Physical material at the surface of the earth, e.g. vegetation or open water, as observable from remote sensing

Landscape*: Scale of analysis of interactions in ecological and social (institutional) sense in areas of land that share important natural capital (e.g. a river, or mountain valley) and that traditionally contained the space in which human livelihoods could be defined; physical dimensions and jurisdictional relationships depend on context; for some of the use of the term the visual dimensions of what can be seen from a terrestrial point of view determine its limits

Land tenure*: Bundle of rights that determine 1) access to, 2) exclusion from, 3) harvest from, 4) management for current function, 5) alternation of function, 6) inheritance and 7) alienation (sale) of land by people belonging to defined social groups, lineage, families or as individuals

Land use*: Management and modification of land cover for specific (human) purposes, such as agriculture, forestry, industrial or urban uses

Legality*: Consistency with the dominant legal system, normally consisting of national laws that are themselves made, changed and based on a constitution

Livelihoods*: Ways of making a living and meeting basic needs

Livestock*: Domesticated animals, including cattle, sheep, goats, chicken, ducks, pigs, buffaloes, camels, horses

Monocultures*: Forms of agriculture or plantation forestry aimed at producing a single crop (considering anything else growing in the same plot to be a weed)

Multisectoral*: Consisting of, or based on cooperation between more than one sector

Natural capital*: the world's stock of natural resources, which includes the earth's crust and its minable minerals and energy reserves, soils, water, air, atmosphere, climate and all living organisms Perennial*: Plant requiring multiple years to complete its life cycle, surviving adverse periods in between growing seasons

Permaculture*: Integrative, perennial-based land use practices

Planetary resources: Atmosphere, oceans and terrestrial plus freshwater systems on planet earth Planetary boundaries: Limits to self-regeneration of planetary resources and global ecosystems in response to human resource use and modification

Plot*: Unit of land managed as a single entity

Policies*: Instruments of governance* by entities that claim the legal right to govern

Private sector*: Part of the economy run by private individuals or groups, usually as a means of enterprise for profit, and not controlled by the state (in contrast to "public sector")

Recycling*: Process of converting waste materials into reusable inputs for subsequent (human) use 
Rehabilitation*: Efforts to make land habitable (fit to live in, for specified organisms) that wasn't before

Resource*: External requirements for plant growth, in particular light (energy), water, nutrients

Restoration: Efforts to bring land back into a condition in which it was before degradation, recovering desired functionality that was lost

Social*: Adjective referring to inter-human relations (or relations between members of the same species in general)

Social capital*: Network of human relations, often based on reciprocity and trust, that allows cooperation for shared purposes in forms of collective action; it can be differentiated in within-group and between-group social capital, and is related to the concept of political capital

Socio-ecological systems*: Systems* in which the interaction between social and ecological subsystems is explicitly acknowledge and subject to feedbacks

Segregate*: Managed in separation, minimizing interactions

Spatial*: pertaining to three dimensional space (latitude, longitude, elevation)

Sustainable development goals*: A set of $17 \mathrm{UN}$-approved goals that define targets, ways of monitoring and means of implementation to improve human wellbeing and reduce negative environmental impacts and feedbacks

Systems*: A perspective on interactions between components (which can be subsystems themselves) that includes positive and negative feedback (change in interaction strength depending on current state)

Temporal*: pertaining to time (usually measures in years or decades)

Trees*: Woody, self-supporting perennial life forms, regardless of the plant family (thus including conifers, broadleaved trees and shrubs, palms and bamboos, but excluding, for example rattans (not self-supporting), sugarcane and tufted grasses (non-woody))

Tree domestication*: Efforts to modify the genetic (and/or phenotypic) makeup of trees, to meet specified selection targets

Value chain*: Chain of steps and actors in which products are transformed and economic value is added, between primary producer and final consumer

Water balance*: Summation over defined spatial and temporal scale of incoming (precipitation (rainfall, snow a.o.), irrigation) and outgoing water by pathway (back to atmosphere, surface water, groundwater), accounting for changes in internal storage

Watershed management*: Governance* of units of land that interact in overland and subsurface flows of water, usually by combination of land use and direct interventions in the flow paths of water

Woody*: Tissue (or plants with such tissue) consisting of strengthened cell walls with cellulose fibers and lignin 


\section{References}

Akiefnawati R, Villamor GB, Zulfikar F, Budisetiawan I, Mulyoutami E, Ayat A and van Noordwijk M. 2010. Stewardship agreement to Reduce Emissions from Deforestation and Degradation (REDD): case study from Lubuk Beringin's Hutan Desa, Jambi Province, Sumatra, Indonesia. International Forestry Review 12(4): 349-360.

Asaah EK, Wanduku TN, Tchoundjeu Z, Kouodiekong L, Van Damme P. 2012. Do propagation methods affect the fine root architecture of African plum (Dacryodes edulis)? Trees 26(5:14611469.

Barrios E. 2007. Soil biota, ecosystem services and land productivity. Ecological economics 64 (2): 269-285.

Binam JN, Place F, Kalinganire A, Hamade S, Boureima M, Tougiani A, Dakouo J, Mounkoro B, Diaminatou S, Badji M, Diop M, Babou AB, Haglund E. 2015. Effects of farmer managed natural regeneration on livelihoods in semi-arid West Africa. Environmental Economics and Policy Studies 17(4): 543-575.

Boserup E.1981. Population and technological change. Chicago, USA: Univ. Chicago Press.

Bradshaw GA, Borchers JG. 2000. Uncertainty as information: narrowing the science-policy gap. Conservation ecology 4(1): 7.

Burgess PJ, den Herder M, Upson M. 2015. Quantifying agroforestry in Europe with a focus on the UK. The Farm Woodland Forum Annual Meeting. Hamstead Marshall, UK, 18 May 2015. United Kingdom: European Union.

Cadisch G, Giller KE, eds. 1997. Driven by nature: plant litter quality and decomposition. Wallingford, UK: CAB international.

Cairns M, Garrity DP. 1999. Improving shifting cultivation in Southeast Asia by building on indigenous fallow management strategies. Agroforestry Systems 47: 37-48.

Cannell MGR, van Noordwijk M, Ong CK. 1996. The central agroforestry hypothesis: the trees must acquire resources that the crop would not otherwise acquire. Agroforestry systems 34(1):.27-31.

Chaplin-Kramer R, Dombeck E, Gerbert J, Knuth KA, Mueller ND, Mueller M, Ziv G, Klein AM. 2014. Global malnutrition overlaps with pollinator-dependent micronutrient production. Proceedings of the Royal Society B 281: 20141799

Clark WC, Tomich TP, van Noordwijk M. Guston D, Catacutan D, Dickson NM, McNie E. 2011. Boundary work for sustainable development: natural resource management at the Consultative Group on International Agricultural Research (CGIAR). Proceedings of the National Academy of Sciences, doi:10.1073/pnas.0900231108

Connell JP, Kubisch AC. 1998. Applying a theory of change approach to the evaluation of comprehensive community initiatives: progress, prospects, and problems. In: Fulbright-Anderson K, Kubisch A and Connell J, eds. 1998. New approaches to evaluating community initiatives 2: Theory, Measurement, and Analysis. Washington DC, USA: Aspen Institute, p. 15-44.

Cooper PJM, Leakey RR, Rao MR, Reynolds L. 1996. Agroforestry and the mitigation of land degradation in the humid and sub-humid tropics of Africa. Experimental Agriculture 32:235-290.

Costanza R, Fioramonti L, Kubiszewski I. 2016. The UN Sustainable Development Goals and the dynamics of well-being. Frontiers in Ecology and the Environment 14(2): 59-59.

de Foresta H, Michon G. 1994. Agroforests in Sumatra: where ecology meets economy. Agroforestry Today 6:12-13

De Foresta H, Michon G. 1996. The agroforest alternative to Imperata grasslands: when smallholder agriculture and forestry reach sustainability. Agroforestry Systems 36(1-3):105-120. 
de Foresta H, Somarriba Chávez E, Temu A, Boulanger D, Feuily H, Gauthier M. 2015. Towards the assessment of trees outside forests. Resources Assessment Working Paper 183, Rome, Italy: FAO.

Demont, M., Jouve, P., Stessens, J. and Tollens, E., 2007. Boserup versus Malthus revisited: Evolution of farming systems in northern Côte d'Ivoire. Agricultural Systems 93(1): 215-228.

den Herder M, Burgess PJ, Mosquera-Losada MR, Herzog F, Hartel T, Upson M, Viholainen I, Rosati A. 2015. Preliminary stratification and quantification of agroforestry in Europe. Milestone Report 1.1 for EU FP7AGFORWARD Research Project (613520). http://agforward.eu/index.php/en/preliminarystratification-and-quantification-of-agroforestry-ineurope.html (accessed 22 April 2015)

Doetterl S, Berhe AA, Nadeu E, Wang Z, Sommer M, Fiener P. 2016. Erosion, deposition and soil carbon: A review of process-level controls, experimental tools and models to address $\mathrm{C}$ cycling in dynamic landscapes. Earth-Science Reviews 154: 102-122.

Dommergues YR. 1987. The role of biological nitrogen fixation in agroforestry. In: Steppler HA, Nair PKR. 1987. Agroforestry: a decade of development. Nairobi, Kenya: International Centre for Research in Agroforestry (ICRAF). p. 245-271.

Dow K, Berkhout F, Preston BL, Klein RJ, Midgley G, Shaw MR. 2013. Limits to adaptation. Nature Climate Change 3(4):.305-307.

Duguma LA, Minang PA, Van Noordwijk M. 2014. Climate change mitigation and adaptation in the land use sector: from complementarity to synergy. Environmental management 54(3): 420-432.

European Commission. 2013. Regulation 1305/2013 of the European Parliament and of the Council of 17 December 2013 on support for rural development by the European Agricultural Fund for Rural Development (EAFRD) and repealing Council Regulation 1698/2005. http://eurlex.europa.eu/LexUriServ/LexUriServ.do?uri=OJ:L:2013:347:0487:0548:EN:PDF

Evans J. 1992. Plantation forestry in the tropics: tree planting for industrial, social, environmental, and agroforestry purposes. Oxford University Press.

Fay C, Michon G. 2005. Redressing forestry hegemony when a forestry regulatory framework is best replaced by an agrarian one. Forests, trees and Livelihoods 15(2): 193-209.

Franzel S. 1999. Socioeconomic factors affecting the adoption potential of improved tree fallows in Africa. Agroforestry systems 47 (1-3): 305-321

Franzel S, Jaenicke H, Janssen W. 1996. Choosing the right trees: setting priorities for multipurpose tree improvement. Den Haag, the Netherlands: ISNAR.

Franzel S, Coe R, Cooper P, Place F, Scherr SJ. 2001. Assessing the adoption potential of agroforestry practices in sub-Saharan Africa. Agricultural systems 69 (1): 37-62

Garrity DP. 2004. Agroforestry and the achievement of the Millennium Development Goals. Agroforestry systems 61(1-3): 5-17.

Garrity D. 2012. Agroforestry and the future of global land use. In: Nair PKR, Garrity D, Eds. 2012. Agroforestry - The Future of Global Land Use. The Netherlands: Springer, p 21-27.

Garrity DP, Soekardi M, Van Noordwijk M, De La Cruz R, Pathak PS, Gunasena HPM, Van So N, Huijun G, Majid NM. 1996. The Imperata grasslands of tropical Asia: area, distribution, and typology. Agroforestry Systems 36(1-3):3-29.

Garrity DP, Akinnifesi FK, Ajayi OC, Weldesemayat SG, Mowo JG, Kalinganire A, Larwanou M, Bayala J. 2010. Evergreen agriculture: a robust approach to sustainable food security in Africa. Food security 2(3): 197-214.

Gaspar P, Escribano M, Mesias FJ. 2016. A qualitative approach to study social perceptions and public policies in dehesa agroforestry systems. Land Use Policy 58: 427-436. 
German L, Mazengia W, Tirwomwe W, Ayele S, Tanui J, Nyangas S, Begashaw L, Taye H, Teferi ZA, Gebremikael MT, Charamila S, Alinyo F, Mekonnen A, Aberra K, Chemangeni A, Cheptegei W, Tolera T, Jotte Z, Bedane K. 2012. Enabling equitable collective action and policy change for poverty reduction and improved natural resource management in the eastern African highlands. In Mwangi E, Markelova H, Meizen-Dick RS, eds. 2012. Collective actions and property rights : insights from Africa and Asia. Philadelphia PA, USA: University of Pennsylvania Press. p.189-234.

German LA, Mowo J, Amede T, Masuki K, eds. 2012. Integrated natural resource management in the highlands of eastern Africa: from concept to practice. New York, USA: Earthscan. 306p.

German L, Mansoor H, Alemu G, Mazengia W, Amede T, Stroud A. 2007. Participatory integrated watershed management: Evolution of concepts and methods in an ecoregional program of the eastern African highlands. Agricultural systems 94(2):189-204.

Giller KE. 2001. Nitrogen fixation in tropical cropping systems. Wallingford, UK: CAB International.

Giller KE, Cadisch G. 1995. Future benefits from biological nitrogen fixation: an ecological approach to agriculture. Plant and Soil 174(1): 255-277

Giller KE, Cadisch G, Ehaliotis C, Adams E, Sakala WD, Mafongoya PL. 1997. Building soil nitrogen capital in Africa. In: Buresh R J, Sanchez P A, Calhoun F. 1997. Replenishing Soil Fertility in Africa. Madison, USA: Soil Science Society of America and American Society of Agronomy. p151-192.

Gillison A N, Liswanti N, Budidarsono S, van Noordwijk M, Tomich TP. 2004. Impact of cropping methods on biodiversity in coffee agroecosystems in Sumatra, Indonesia. Ecology and Society 9(2): 7

Gouyon A, de Foresta H, Levang P. 1993. Does 'jungle rubber'deserve its name? An analysis of rubber agroforestry systems in southeast Sumatra. Agroforestry systems 22(3):181-206.

Harvey CA, Chacon M, Donatti CI, Garen E, Hannah L, Andrade A, Bede L, Brown D, Calle A, Chara J, Clement C. 2014. Climate-Smart Landscapes: Opportunities and Challenges for Integrating Adaptation and Mitigation in Tropical Agriculture. Conservation Letters 7(2): 77-90.

Hayami Y, Ruttan VW. 1985. Agricultural Development: An International Perspective. Baltimore, USA: Johns Hopkins University Press.

ICRAF. 1982. Concepts and procedures for diagnosis of existing land management systems and design of agroforestry technology: a preliminary version for comment. Nairobi, Kenya: International Centre for Research in Agroforestry (ICRAF).

Hoekstra DA. 1987. Economics of agroforestry. Agroforestry systems 5(3): 293-300.

Huxley P. 1999. Tropical agroforestry. Oxford: Blackwell Science.

Izac AM, Sanchez PA. 2001. Towards a natural resource management paradigm for international agriculture: the example of agroforestry research. Agricultural systems 69(1): 5-25.

Jackson LE, van Noordwijk M, Bengtsson J, Foster W, Lipper L, Pulleman M, Said M, Snaddon J, Vodouhe R. 2010. Biodiversity and agricultural sustainagility: from assessment to adaptive management. Current Opinion in Environmental Sustainability 2:80-87

Jamnadass R, Place F, Torquebiau E, Malézieux E, Iiyama M, Sileshi GW, Kehlenbeck K, Masters E, McMullin S, Dawson IK. 2013. Agroforestry for food and nutritional security. Unasylva 64(2): 23-29.

Jose S. 2009. Agroforestry for ecosystem services and environmental benefits: an overview. Agroforestry Systems 76: 1-10.

Kho RM. 2000. A general tree-environment-crop interaction equation for predictive understanding of agroforestry systems. Agriculture, ecosystems and environment 80(1): 87-100. 
King KFS. 1987. The history of agroforestry. In: Steppler HA, Nair PKR, eds. 1987. Agroforestry: A Decade of Development. Nairobi, Kenya: International Centre for Research in Agroforestry (ICRAF). p1-11.

Kindt R, Coe R. 2005. Tree diversity analysis: A manual and software for common statistical methods for ecological and biodiversity studies. Nairobi, Kenya: World Agroforestry Centre (ICRAF)

Kiptot E, Hebinck P, Franzel S, Richards P. 2007. Adopters, testers or pseudo-adopters? Dynamics of the use of improved tree fallows by farmers in western Kenya. Agricultural Systems 94 (2): 509519

Kiptot E, Franzel S, Hebinck P, Richards R. 2006. Sharing seed and knowledge: farmer to farmer dissemination of agroforestry technologies in western Kenya. Agroforestry Systems 68 (3): 167179

Kristjanson P, Reid RS, Dickson N, Clark WC, Romney D, Puskur R, MacMillan S, Grace D. 2009. Linking international agricultural research knowledge with action for sustainable development. Proceedings of the National Academy of Sciences 106: 5047-5052

Kusters K, De Foresta H, Ekadinata A, van Noordwijk M. 2007. Towards solutions for state vs. local community conflicts over forestland: the impact of formal recognition of user rights in Krui, Sumatra, Indonesia. Human Ecology 35: 427-438.

Kusters K, Pérez MR, De Foresta H, Dietz T, Ros-Tonen M, Belcher B, Manalu P, Nawir A, Wollenberg E. 2008. Will agroforests vanish? The case of Damar agroforests in Indonesia. Human Ecology 36: 357-370.

Lang DJ, Wiek A, Bergmann M, Stauffacher M, Martens P, Moll P, Swilling M,Thomas CJ. 2012. Transdisciplinary research in sustainability science: practice, principles, and challenges. Sustainability Science 7: 25-43.

Leakey RR, Simons AJ. 1997. The domestication and commercialization of indigenous trees in agroforestry for the alleviation of poverty. Agroforestry Systems 38, 165-176.

Leakey RR. 1999. Potential for novel food products from agroforestry trees: a review. Food Chemistry 66: 1-14.

Leakey RRB. 1996. Definition of agroforestry revisited. Agroforestry Today. Nairobi, Kenya: International Centre for Research in Agroforestry (ICRAF).

Leimona B, van Noordwijk M, de Groot R, Leemans R. 2015. Fairly efficient, efficiently fair: Lessons from designing and testing payment schemes for ecosystem services in Asia. Ecosystem Services 12: 16-28

Mbow C, van Noordwijk M, Luedeling E, Neufeldt H, Minang PA, Kowero G. 2014. Agroforestry solutions to address food security and climate change challenges in Africa. Current Opinion in Environmental Sustainability 6: 61-67.

McNeely JA, Scherr SJ. 2003. Ecoagriculture: strategies to feed the world and save wild biodiversity. Washington, DC: Island Press, 323 pp

Meadows D, Randers J, Meadows D. 2004. Limits to growth: The 30-year update. Chelsea: Green Publishing.

Mercado Jr AR, Patindol M, Garrity DP. 2001. The Landcare experience in the Philippines: Technical and institutional innovations for conservation farming. Development in practice 11(4): 495-508.

Michon G. 2005. Domesticating forests: how farmers manage forest resources. Bogor, Indonesia: IRD, Center for International Forestry Research (CIFOR), World Agroforestry Centre - ICRAF, SEA Regional Office. $187 \mathrm{p}$

Michon G and de Foresta H. 1996. Agroforests as an alternative to pure plantations for the domestication and commercialization of NTFPs. Domestication and commercialization of NonTimber Forest Products in agroforestry systems. Proceedings of the international conference, 19- 
23 February 1996, Nairobi, Kenya. Bangkok, Thailand: FAO Regional Office for Asia and the Pacific (RAP). p160-175.

Michon G, de Foresta H, Levang P, Verdeaux F. 2007. Domestic forests: a new paradigm for integrating local communities' forestry into tropical forest science. Ecology and Society 12(2).

Michon, G., Mary, F, Bompard J.1986. Multistoried agroforestry garden system in West Sumatra, Indonesia. Agroforestry Systems 4(4): 315-338

Millennium Ecosystem Assessment (MEA).2005. Ecosystems and human well-being: synthesis. Washington, DC: Island Press, $155 \mathrm{pp}$

Minang PA, van Noordwijk M. 2013. Design challenges for achieving reduced emissions from deforestation and forest degradation through conservation: leveraging multiple paradigms at the tropical forest margins. Land Use Policy 31: 61-70.

Minang PA, van Noordwijk M, Kahurani E, Eds. 2014a. Partnership in the Tropical Forest Margins: a 20-Year Journey in Search of Alternatives to Slash-and-Burn. Nairobi, Kenya: World Agroforestry Centre (ICRAF), $241 \mathrm{p}$.

Minang PA, van Noordwijk M. 2014b. The political economy of Readiness for REDD+. Climate Policy 14: 677-684

Minang PA, van Noordwijk M, Freeman OE, Mbow C, de Leeuw J, Catacutan D, Eds .2015. ClimateSmart Landscapes: Multifunctionality in Practice. Nairobi, Kenya: World Agroforestry Centre (ICRAF). ISBN 978-92-9059-375-1

Nair PKR. 1985. Classification of agroforestry systems. Agroforestry Systems 3(2): 97-128.

Nair .R. 1993. An introduction to agroforestry. Netherlands: Kluwer Academic Publishers.. 499p.

Nair PKR. 1998. Directions in tropical agroforestry research: past, present, and future. Agroforestry Systems 38:223-245.

Namirembe S, Leimona B, van Noordwijk M, Bernard F, Bacwayo KE. 2014. Co-investment paradigms as alternatives to payments for tree-based ecosystem services in Africa. Current Opinion in Environmental Sustainability 6: 89-97.

Nerlich K, Graeff-Hönninger S, Claupein W. 2013. Agroforestry in Europe: a review of the disappearance of traditional systems and development of modern agroforestry practices, with emphasis on experiences in Germany. Agroforestry Systems 87(2): 475-492.

Nowotny H, Scott PB, Gibbons MT. 2013. Re-thinking science: Knowledge and the public in an age of uncertainty. John Wiley \& Sons. 288p

Opondo C, Sanginga P, Stroud A. 2003. Monitoring the outcomes of participatory research in natural resource management: Experiences of the African Highlands Initiative. In Wettasinha $\mathrm{C}$, van Veldhuizen L, Waters-Bayer A, eds.2003. Advancing Participatory Technology Development: Case Studies on Integration into Agricultural Research, Extension and Education, p.39-60.

Ong CK, Huxley P. 1996. Tree-crop interactions: a physiological approach. Wallingford, UK: CAB International.

Ong CK, Corlett JE, Singh RP, Black CR. 1991. Above and below ground interactions in agroforestry systems. Forest Ecology and Management 45(1): 45-57.

Ong CK, Kho RM. 2015. A framework for quantifying the various effects of tree-crop interactions. In Ong CK, Black CR, Wilson J, Eds.2015. Tree-crop interactions, 2nd edition: agroforestry in a changing climate. Wallingford, UK: CAB International. p 1-23.

Orwa C, Mutua A, Kindt R, Jamnadass R, Simons A. 2009. Agroforestry Database: a tree reference and selection guide version 4.0. Nairobi, Kenya: World Agroforestry Centre (ICRAF) 
Palm CA, Gachengo CN, Delve RJ, Cadisch G, Giller KE. 2001. Organic inputs for soil fertility management in tropical agroecosystems: application of an organic resource database. Agriculture, Ecosystems and Environment 83(1): 27-42.

Palm C A, Tomich T, Van Noordwijk M, Vosti S, Gockowski J, Alegre J, Verchot L. 2004. Mitigating GHG emissions in the humid tropics: case studies from the Alternatives to Slash and Burn Program (ASB). Environment, Development and Sustainability 6: 145-162.

Paustian K, Andrén O, Janzen HH, Lal R, Smith P, Tian G, Tiessen H, Van Noordwijk M, Woomer PL. 1997. Agricultural soils as a sink to mitigate CO2 emissions. Soil Use and Management 13: 230-244

Phiri D, Franzel S, Mafongoya P, Jere I, Katanga R, Phiri S. 2004. Who is using the new technology? The association of wealth status and gender with the planting of improved tree fallows in Eastern Province, Zambia. Agricultural Systems 79 (2): 131-144

Pielke Jr RA. 2007. The honest broker: making sense of science in policy and politics. Cambridge, UK: Cambridge University Press. 200p.

Pretty J, Sutherland WJ, Ashby J, Auburn J, Baulcombe D, Bell M, .... 2010. The top 100 questions of importance to the future of global agriculture. International Journal of Agricultural Sustainability 8 (4): $219-236$

Raintree JB. 1987. The state of the art of agroforestry diagnosis and design. Agroforestry Systems, 5(3): 219-250.

Raintree JB, Warner K. 1986. Agroforestry pathways for the intensification of shifting cultivation. Agroforestry Systems 4(1): 39-54

Ramadhani T, Otsyina R, Franzel S. 2002. Improving household incomes and reducing deforestation using rotational woodlots in Tabora district, Tanzania. Agriculture, Ecosystems and Environment 89 (3): $229-239$

Ranieri SBL, Stirzaker R, Suprayogo D, Purwanto E, de Willigen P, and van Noordwijk M. 2004. Managing movements of water, solutes and soil: from plot to landscape scale. In: van Noordwijk M, Cadisch G, Ong CK, eds.2004. Belowground Interactions in Tropical Agroecosystems. Wallingford, UK: CAB International. p 329-347

Rao MR, Nair PKR, Ong CK. 1998. Biophysical interactions in tropical agroforestry systems. In: Nair PKR, Latt CR, eds. 1998. Directions in Tropical Agroforestry Research. The the Netherlands: Kluwer Academic Publishers. p3-50.

Reid RS, Tomich TP, Xu J, Geist H, Mather A, DeFries RS, Liu J, Alves D, Agbola B, Lambin EF, Chabbra A, Veldkamp T, Kok K, van Noordwijk M, Thomas DE, Palm CA, Verburg PH. 2006. Linking Land-Change Science and Policy: Current lessons and future integration. In: Lambin EF and Geist H, eds. 2006. Land-Use and Land-Cover Change: Local processes and global impacts. Verlag Berlin Heidelberg: Springer. p157-171.

Rockström J, Steffen WL, Noone K, Persson A, Chapin III FS, Lambin E, Lenton TM, Scheffer M, Folke C, Schellnhuber HJ, Nykvist B. 2009. Planetary boundaries: exploring the safe operating space for humanity. Ecology and Society 14(2): 32. URL: http://www.ecologyandsociety.org/vol14/iss2/art32/

Roothaert RL, Franzel S. 2001. Farmers' preferences and use of local fodder trees and shrubs in Kenya. Agroforestry Systems 52 (3): 239-252

Rowe EC, van Noordwijk M, Suprayogo D, Hairiah K, Giller KE, Cadisch G. 2001. Root distributions partially explain $15 \mathrm{~N}$ uptake patterns in Gliricidia and Peltophorum hedgerow intercropping systems. Plant and Soil 235(2): 167-179.

Rudel TK, Coomes OT, Moran E, Achard F, Angelsen A, Xu J, Lambin E. 2001. Forest transitions: towards a global understanding of land use change. Global Environmental Change 15: 23-31 
Russell D, Franzel S. 2004. Trees of prosperity: agroforestry, markets and the African smallholder. Agroforestry Systems 61: 345-355

Ruttan VW. 1997. Induced innovation, evolutionary theory and path dependence: sources of technical change. The Economic Journal 107(444): 1520-1529.

Sánchez PA, Salinas JG. 1981. Low-input technology for managing oxisols and ultisols in tropical America. Advances in Agronomy 34: 279-406.

Sanchez PA. 1994. Tropical soil fertility research: towards the second paradigm. Transactions 15th World Congress of Soil Science (Acapulco, Mexico) 1: 65-88.

Sanchez PA. 1995. Science in agroforestry. Agroforestry Systems 30:5-55.

Sanchez PA. 2002. Soil fertility and hunger in Africa. Science 295(5562): 2019-2020.

Sanchez PA, Shepherd KD, Soule MJ, Place FM, Buresh RJ, Izac AMN, Mokwunye AU, Kwesiga FR, Ndiritu CG, Woomer PL. 1997. Soil fertility replenishment in Africa: an investment in natural resource capital. Replenishing soil fertility in Africa, ASA, p.1-46.

Scherr SJ. 1995. Economic factors in farmer adoption of agroforestry: Patterns observed in western Kenya. World development 23(5): 787-804.

Scherr SJ, Hazell PBR. 1994. Sustainable agricultural development strategies in fragile lands. Discussion Paper No. 1. Washington DC: International Food Policy Research Institute (IFPRI).

Sendzimir J, Reij CP, Magnuszewski P. 2011. Rebuilding resilience in the Sahel: regreening in the Maradi and Zinder regions of Niger. Ecology and Society 16(3).

Shelton HM, Brewbaker JL. 1998. 2.1 Leucaenaleucocephala-the most widely used forage tree legume. In: Gutteridge RC, Shelton HM, eds. 1998. Forage Tree Legumes in Tropical Agriculture. Queensland, Australia: Tropical Grassland Society of Australia Inc. http://www. fao.org/ag/AGP/AGPC/doc/Publicat/Guttshel/x5556e06.

Siegel KR, Ali MK, Srinivasiah A, Nugent RA, Narayan KV. 2014. Do we produce enough fruits and vegetables to meet global health need? PloS one 9(8). DOI: 10.1371/journal.pone.0104059

Simons AJ, Leakey RRB. 2004. Tree domestication in tropical agroforestry. In: Nair PKR, Rao MR, Buck LE, eds. 2004. New vistas in agroforestry. The Netherlands: Kluwer Academic Publishers. p167-181.

Sinclair FL. 1999. A general classification of agroforestry practice. Agroforestry Systems 46(2): 161180.

Somarriba E. 1992. Revisiting the past: an essay on agroforestry definition. Agroforestry Systems 19(3): 233-240.

Swallow BM, Garrity DP, Van Noordwijk M. 2002. The effects of scales, flows and filters on property rights and collective action in watershed management. Water policy 3(6): 457-474.

Swallow BM, Kallesoe MF, Iftikhar UA, van Noordwijk M, Bracer C, .... 2009. Compensation and rewards for environmental services in the developing world: framing pan-tropical analysis and comparison. Ecology and Society 14 (2): 26

Swift MJ, Izac AMN, Van Noordwijk M. 2004. Biodiversity and ecosystem services in agricultural landscapes: Are we asking the right questions? Agriculture, Ecosystems and Environment 104: 113-134

Swinkels RA, Scherr SJ. 1992. Economic analysis of agroforestry technologies. An annotated bibliography. Nairobi: International Centre for Research in Agroforestry (ICRAF)

Swinkels RA, Franzel S, Shepherd KD, Ohlsson E, Ndufa JK. 1997. The economics of short rotation improved fallows: evidence from areas of high population density in western Kenya Agricultural Systems 55 (1): 99-121 
Taleb NN. 2012. Antifragile: how to live in a world we don't understand (Vol. 3). London: Allen Lane.

Thapa B, Sinclair FL, Walker DH. 1995. Incorporation of indigenous knowledge and perspectives in agroforestry development. Agroforestry Systems 30(1-2): 249-261.

Tiffen M, Mortimore M. 1994. Malthus controverted: The role of capital and technology in growth and environment recovery in Kenya. World Development 22(7): 997-1010.

Tomich TP, Kuusipalo J, Menz K, Byron N. 1996. Imperata economics and policy. Agroforestry Systems 36(1-3): 233-261.

Tomich TT, Fagi AM, De Foresta H, Michon G, Murdiyarso D, Stolle F, Van Noordwijk M. 1998. Indonesia's fires: smoke as a problem, smoke as a symptom. Agroforestry Today. Bogor, Indonesia: International Centre for Research in Agroforestry (ICRAF).

Tomich TP, Van Noordwijk M, Thomas DE, Eds. 2004a. Environmental Services and Land Use Change: Bridging the Gap between Policy and Research in Southeast Asia. Special Issue of Agriculture Ecosystems and Environment 104.

Tomich TP, van Noordwijk M, Thomas DE. 2004b. Environmental services and land use change in Southeast Asia: from recognition to regulation or reward? Agriculture, Ecosystems and Environment 104: 229-244

Tomich TP, Chomitz K, Francisco H, Izac AM, Murdiyarso D, Ratner B, Thomas DE, Van Noordwijk M. 2004c. Asking the right questions: Policy analysis and environmental problems at different scales. Agriculture, Ecosystems and Environment 104: 5-18

Tomich TP, Cattaneo A, Chater S, Geist HJ, Gockowski J, Kaimowitz D, Lambin EF, Lewis J, Ndoye O, Palm C, Stolle F, Sunderlin WD, Valentim JF, van Noordwijk M, Vosti SA. 2005. Balancing Agricultural Development and Environmental Objectives: Assessing Tradeoffs in the Humid Tropics. In: Palm CA, Vosti SA, Sanchez PA, Ericksen PJ, Juo ASR,Eds. 2005. Slash and Burn: The Search for Alternatives. New York, USA:Columbia University Press, p415-440

Tomich TP, Palm CA, Velarde SJ, Geist H, Gillison AN, Lebel L, Locatelli N, Mala W, van Noordwijk M, Sebastian K, Timmer D, White D. 2005. Forest and agroecosystem tradeoffs in the humid tropics: an assessment of ecosystem health and human well-being in tropical forest margins. A cross-cutting assessment by the Alternatives to Slash and Burn consortium conducted as a sub-global component of the Millenium Ecosystem Assessment.Nairobi, Kenya: Alternativesto-Slash-and-Burn Programme. 163p.

Tomich TP, Timmer DW, Velarde SJ, Alegre J, Areskoug V, Cash DW, Cattaneo A, Cornelius J, Ericksen P, Joshi L, Kasyoki J, Legg C, Locatelli M, Murdiyarso D, Palm C, Porro R, Perazzo AR, Salazar-Vega A, van Noordwijk M, Weise S, White D. 2007. Integrative science in practice: process perspectives from ASB, the Partnership for the Tropical Forest Margins. Agriculture Ecosystems and Environment 9: 269-286

Torquebiau EF. 1986. Mosaic patterns in dipterocarp rain forest in Indonesia, and their implications for practical forestry. Journal of Tropical Ecology 2(04):.301-325.

Torquebiau E. 1992. Are tropical agroforestry home gardens sustainable?. Agriculture, Ecosystems and Environment 41(2): 189-207.

Torquebiau EF. 2000. A renewed perspective on agroforestry concepts andclassification. Comptes Rendus de l'Academie des Sciences-Series III-Sciences de la Vie 323(11):1009-1017.

Torquebiau E, Taylor RD. 2009. Natural resource management by rural citizens in developing countries: innovations still required. Biodiversity and Conservation 18(10): 2537-2550.

Turner BL, Ali AS. 1996. Induced intensification: Agricultural change in Bangladesh with implications for Malthus and Boserup. Proceedings of the National Academy of Sciences 93(25): 14984-14991. 
van Noordwijk M. 1989. Rooting depth in cropping systems in the humid tropics in relation to nutrient use efficiency. Nutrient Management for Food Crop Production in Tropical Farming Systems: 129-144.

van Noordwijk M. 2014. Agroforestry as plant production system in a multifunctional landscape. Inaugural lecture upon taking up the special professorship in Agroforestry at Wageningen University 16 October 2014. . Wageningen, Netherlands: Wageningen University. 24 p.

van Noordwijk M, Ong CK. 1996. Lateral resource flow and capture-the key to scaling up agroforestry results. Agroforestry Forum 7(3): 29-31.

van Noordwijk M, Hairiah K, Partoharjono S, Labios RV, Garrity DP. 1996. Food-crop-based production systems as sustainable alternatives for Imperata grasslands? Agroforestry Systems 36(1-3): 55-82.

van Noordwijk M, Tomich TP, De Foresta H, Michon G. 1997a. To segregate-or to integrate? The question of balance between production and biodiversity conservation in complex agroforestry systems. Agroforestry Today. Bogor, Indonesia: International Centre for Research in Agroforestry (ICRAF) Southeast Asia

van Noordwijk M, Woomer P, Cerri C, Bernoux M, Nugroho K. 1997b. Soil carbon in the humid tropical forest zone. Geoderma 79: 187-225

van Noordwijk M, Roode MV, McCallie EL, Lusiana B, Penning de Vries FWT, Agus F, Kerr J. 1998. Erosion and sedimentation as multiscale, fractal processes: implications for models, experiments and the real world. In: Penning de Vries FWT, Agus F, Kerr J, eds. 1998. Soil erosion at multiple scales: principles and methods for assessing causes and impacts. Wallingford, UK: CAB International. p223-253.

van Noordwijk M, Tomich TP,Verbist B. 2001. Negotiation support models for integrated natural resource management in tropical forest margins. Conservation Ecology 5(2): 21. [online] URL: http://www.consecol.org/vol5/iss2/art21

van Noordwijk M, Williams SE, Verbist B, Eds. 2001.Towards integrated natural resource management in forest margins of the humid tropics: local action and global concerns. ASBLecture Notes. Nairobi: ASB Partnership for the Tropical Forest Margins

van Noordwijk M, Cadisch G, Ong CK, Eds. 2004a. Belowground Interactions in Tropical Agroecosystems. Wallingford,UK: CAB International. 580p.

van Noordwijk M, Chandler F, Tomich TP. 2004b. An introduction to the conceptual basis of RUPES: rewarding upland poor for the environmental services they provide. Bogor, Indonesia: International Centre for Research in Agroforestry (ICRAF) Southeast Asia 41p

van Noordwijk M, Agus F, Verbist B, Hairiah K, Tomich TP. 2007. Managing Watershed Services in Ecoagriculture Landscapes. In: Scherr SJ, McNeely JA, eds. 2007. Farming with Nature: The Science and Practice of Ecoagriculture. Washington DC, USA: Island Pressp 191 - 212.

van Noordwijk M, Roshetko JM, Murniati, Angeles MD, Suyanto, Fay C, Tomich TP. 2008. Farmer Tree Planting Barriers to Sustainable Forest Management. In: Snelder DJ,Lasco RD, Eds. 2008. Smallholder Tree Growing for Rural Development and Environmental Services: Lessons from Asia. Advances in Agroforestry Volume 5. Berlin: Springer. p 427-449

van Noordwijk M, Hoang MH, Neufeldt H, Öborn I, Yatich T. 2011. How trees and people can coadapt to climate change: reducing vulnerability through multifunctional agroforestry landscapes. Nairobi: World Agroforestry Centre (ICRAF). 134p.

van Noordwijk M, Leimona B, Jindal R, Villamor GB, Vardhan M, Namirembe S, Catacutan D, Kerr J, Minang PA, Tomich TP. 2012a. Payments for environmental services: evolution toward efficient and fair incentives for multifunctional landscapes. Annual Review of Environment and Resources 37: 389-420. 
van Noordwijk M, Tata HL, Xu J, Dewi S, Minang PA. 2012b. Segregate or integrate for multifunctionality and sustained change through rubber-based agroforestry in Indonesia and China. In: Nair PKR, Garrity D, eds. 2012. Agroforestry-The Future of Global Land Use. The Netherlands: Springer. p69-104. .

van Noordwijk M, Lusiana B, Leimona B, Dewi S, Wulandari D, eds. 2013. Negotiation-support toolkit for learning landscapes. Bogor, Indonesia: World Agroforestry Centre (ICRAF) Southeast Asia Regional Program.

van Noordwijk M, Bayala J, Hairiah K, Lusiana B, Muthuri C, Khasanah N, Mulia R. 2014. Agroforestry solutions for buffering climate variability and adapting to change. Chapter 14 in: Fuhrer J, Gregory PJ, Eds. Climate change Impact and Adaptation in Agricultural Systems. Wallingford, UK: CAB-International. p 216-232

van Noordwijk M, Agus F, Dewi S, Purnomo, H. 2014b. Reducing emissions from land use in Indonesia: motivation, policy instruments and expected funding streams. Mitigation and Adaptation Strategy for Global Change 19(6): 677-692

van Noordwijk M, Namirembe S, Catacutan DC, Williamson D, Gebrekirstos A. 2014c. Pricing rainbow, green, blue and grey water: tree cover and geopolitics of climatic teleconnections. Current Opinion in Environmental Sustainability 6: 41-47.

van Noordwijk M, Barrios E, Shepherd K, Bayala J, Oborn I. 2015a. The rooted pedon in a dynamic multifunctional landscape: Soil science at the World Agroforestry Centre. Working Paper 200. Nairobi, Kenya: World Agroforestry Centre (ICRAF).

van Noordwijk M, Bruijnzeel S, Ellison D, Sheil D, Morris C, Gutierrez V, Cohen J, Sullivan C, Verbist B, Muys B. 2015b. Ecological rainfall infrastructure: investment in trees for sustainable development. ASB Brief 47. Nairobi, Kenya: ASB Partnership for the Tropical Forest Margins. 6p

Vandermeer J, van Noordwijk M, Anderson J, Ong CK, Perfecto I. 1998. Global change and multispecies agroecosystems: concepts and issues. Agriculture, Ecosystems and Environment 67(1):122.

Verchot LV, Van Noordwijk M, Kandji S, Tomich TP, Ong CK, Albrecht A, Mackensen J, Bantilan C, Anupama KV, Palm C. 2007. Climate change: linking adaptation and mitigation through agroforestry. Mitigation and adaptation strategies for global change 12(5): 901-918.

Verma R, Russell D, German L. 2010. Anthroapology? negotiating space for interdisciplinary collaboration and in-depth anthropology in the CGIAR. In: German L, Ramisch JJ, Verma R, eds. 2010. Beyond the Biophysical Knowledge, Culture, and Politics in Agriculture and Natural Resource Management. The Netherlands: Springer. p257-281

Villamor GB, Le QB, Djanibekov U, van Noordwijk M, Vlek PLG. 2014. Biodiversity in rubber agroforests, carbon emissions, and rural livelihoods: An agent-based model of land-use dynamics in lowland Sumatra. Environmental Modelling and Software 61: 151-165

Wang'Ati F. 1994. The African Highlands Initiative: A Conceptual Framework. Nairobi, Kenya: International Centre for Research in Agroforestry (ICRAF). 24p.

Weiss CH. 1997. How Can Theory-Based Evaluation Make Greater Headway? Evaluation Review 21, No. 4.

Wiersum KF. 1997. Indigenous exploitation and management of tropical forest resources: an evolutionary continuum in forest-people interactions. Agriculture, ecosystems \& environment 63: $1-16$

Wood PJ, Burley J. 1991. A tree for all reasons: the introduction and evaluation of multipurpose trees for agroforestry. Nairobi, Kenya: International Centre for Research in Agroforestry (ICRAF).

Young A. 1997. Agroforestry for soil management. Wallingford, UK: CAB international. 32p. 
Zomer RJ, Trabucco A, Bossio DA, Verchot LV. 2008. Climate change mitigation: A spatial analysis of global land suitability for clean development mechanism afforestation and reforestation.

Agriculture, Ecosystems and Environment 126 (1): 67-80

Zomer RJ, Trabucco A, Coe R, Place F. 2009. Trees on farm: analysis of global extent and geographical patterns of agroforestry. Working Paper 89. Nairobi, Kenya: World Agroforestry Centre (ICRAF)

Zomer RJ, Trabucco A, Coe R, Place F, van Noordwijk M, Xu JC. 2014. Trees on farms: an update and reanalysis of agroforestry's global extent and socio-ecological characteristics. Working Paper 179. Nairobi, Kenya: World Agroforestry Centre (ICRAF)

Zomer RJ, Neufeldt H, Xu J, Ahrends A, Bossio DA, Trabucco A, van Noordwijk M, Wang M. 2016. Global tree cover and biomass carbon on agricultural land: The contribution of agroforestry to global and national carbon budgets. Scientific Reports 6 No. 29987 


\section{WORKING PAPERS WITH DOIS}

\section{5}

1. Agroforestry in the drylands of eastern Africa: a call to action

2. Biodiversity conservation through agroforestry: managing tree species diversity within a network of community-based, nongovernmental, governmental and research organizations in western Kenya.

3. Invasion of prosopis juliflora and local livelihoods: Case study from the Lake Baringo area of Kenya

4. Leadership for change in farmers organizations: Training report: Ridar Hotel, Kampala, 29th March to 2nd April 2005.

5. Domestication des espèces agroforestières au Sahel : situation actuelle et perspectives

6. Relevé des données de biodiversité ligneuse: Manuel du projet biodiversité des parcs agroforestiers au Sahel

7. Improved land management in the Lake Victoria Basin: TransVic Project's draft report.

8. Livelihood capital, strategies and outcomes in the Taita hills of Kenya

9. Les espèces ligneuses et leurs usages: Les préférences des paysans dans le Cercle de Ségou, au Mali

10. La biodiversité des espèces ligneuses: Diversité arborée et unités de gestion du terroir dans le Cercle de Ségou, au Mali

\section{6}

11. Bird diversity and land use on the slopes of Mt. Kilimanjaro and the adjacent plains, Tanzania

12. Water, women and local social organization in the Western Kenya Highlands

13. Highlights of ongoing research of the World Agroforestry Centre in Indonesia

14. Prospects of adoption of tree-based systems in a rural landscape and its likely impacts on carbon stocks and farmers' welfare: The FALLOW Model Application in Muara Sungkai, Lampung, Sumatra, in a 'Clean Development Mechanism' context

15. Equipping integrated natural resource managers for healthy Agroforestry landscapes.

17. Agro-biodiversity and CGIAR tree and forest science: approaches and examples from Sumatra.

18. Improving land management in eastern and southern Africa: A review of policies.

19. Farm and household economic study of Kecamatan Nanggung, Kabupaten Bogor, Indonesia: A socioeconomic base line study of Agroforestry innovations and livelihood enhancement.

20. Lessons from eastern Africa's unsustainable charcoal business.

21. Evolution of RELMA's approaches to land management: Lessons from two decades of research and development in eastern and southern Africa

22. Participatory watershed management: Lessons from RELMA's work with farmers in eastern Africa.

23. Strengthening farmers' organizations: The experience of RELMA and ULAMP.

24. Promoting rainwater harvesting in eastern and southern Africa.

25. The role of livestock in integrated land management.

26. Status of carbon sequestration projects in Africa: Potential benefits and challenges to scaling up.

27. Social and Environmental Trade-Offs in Tree Species Selection: A Methodology for Identifying Niche Incompatibilities in Agroforestry [Appears as AHI Working Paper no. 9]

28. Managing tradeoffs in agroforestry: From conflict to collaboration in natural resource management. [Appears as AHI Working Paper no. 10]

29. Essai d'analyse de la prise en compte des systemes agroforestiers pa les legislations forestieres au Sahel: Cas du Burkina Faso, du Mali, du Niger et du Senegal.

30. Etat de la recherche agroforestière au Rwanda etude bibliographique, période 1987-2003 
31. Science and technological innovations for improving soil fertility and management in Africa: A report for NEPAD's Science and Technology Forum.

32. Compensation and rewards for environmental services.

33. Latin American regional workshop report compensation.

34. Asia regional workshop on compensation ecosystem services.

35. Report of African regional workshop on compensation ecosystem services.

36. Exploring the inter-linkages among and between compensation and rewards for ecosystem services CRES and human well-being

37. Criteria and indicators for environmental service compensation and reward mechanisms: realistic, voluntary, conditional and pro-poor

38. The conditions for effective mechanisms of compensation and rewards for environmental services.

39. Organization and governance for fostering Pro-Poor Compensation for Environmental Services.

40. How important are different types of compensation and reward mechanisms shaping poverty and ecosystem services across Africa, Asia \& Latin America over the Next two decades?

41. Risk mitigation in contract farming: The case of poultry, cotton, woodfuel and cereals in East Africa.

42. The RELMA savings and credit experiences: Sowing the seed of sustainability

43. Yatich J., Policy and institutional context for NRM in Kenya: Challenges and opportunities for Landcare.

44. Nina-Nina Adoung Nasional di So! Field test of rapid land tenure assessment (RATA) in the Batang Toru Watershed, North Sumatera.

45. Is Hutan Tanaman Rakyat a new paradigm in community based tree planting in Indonesia?

46. Socio-Economic aspects of brackish water aquaculture (Tambak) production in Nanggroe Aceh Darrusalam.

47. Farmer livelihoods in the humid forest and moist savannah zones of Cameroon.

48. Domestication, genre et vulnérabilité : Participation des femmes, des Jeunes et des catégories les plus pauvres à la domestication des arbres agroforestiers au Cameroun.

49. Land tenure and management in the districts around Mt Elgon: An assessment presented to the Mt Elgon ecosystem conservation programme.

50. The production and marketing of leaf meal from fodder shrubs in Tanga, Tanzania: A pro-poor enterprise for improving livestock productivity.

51. Buyers Perspective on Environmental Services (ES) and Commoditization as an approach to liberate ES markets in the Philippines.

52. Towards Towards community-driven conservation in southwest China: Reconciling state and local perceptions.

53. Biofuels in China: An Analysis of the Opportunities and Challenges of Jatropha curcas in Southwest China.

54. Jatropha curcas biodiesel production in Kenya: Economics and potential value chain development for smallholder farmers

55. Livelihoods and Forest Resources in Aceh and Nias for a Sustainable Forest Resource Management and Economic Progress

56. Agroforestry on the interface of Orangutan Conservation and Sustainable Livelihoods in Batang Toru, North Sumatra. 
57. Assessing Hydrological Situation of Kapuas Hulu Basin, Kapuas Hulu Regency, West Kalimantan.

58. Assessing the Hydrological Situation of Talau Watershed, Belu Regency, East Nusa Tenggara.

59. Kajian Kondisi Hidrologis DAS Talau, Kabupaten Belu, Nusa Tenggara Timur.

60. Kajian Kondisi Hidrologis DAS Kapuas Hulu, Kabupaten Kapuas Hulu, Kalimantan Barat.

61. Lessons learned from community capacity building activities to support agroforest as sustainable economic alternatives in Batang Toru orang utan habitat conservation program (Martini, Endri et al.)

62. Mainstreaming Climate Change in the Philippines.

63. A Conjoint Analysis of Farmer Preferences for Community Forestry Contracts in the Sumber Jaya Watershed, Indonesia.

64. The highlands: a shared water tower in a changing climate and changing Asia

65. Eco-Certification: Can It Deliver Conservation and Development in the Tropics.

66. Designing ecological and biodiversity sampling strategies. Towards mainstreaming climate change in grassland management.

67. Towards mainstreaming climate change in grassland management policies and practices on the Tibetan Plateau

68. An Assessment of the Potential for Carbon Finance in Rangelands

69 ECA Trade-offs Among Ecosystem Services in the Lake Victoria Basin.

69. The last remnants of mega biodiversity in West Java and Banten: an in-depth exploration of RaTA (Rapid Land Tenure Assessment) in Mount Halimun-Salak National Park Indonesia

70. Le business plan d'une petite entreprise rurale de production et de commercialisation des plants des arbres locaux. Cas de quatre pépinières rurales au Cameroun.

71. Les unités de transformation des produits forestiers non ligneux alimentaires au Cameroun. Diagnostic technique et stratégie de développement Honoré Tabuna et Ingratia Kayitavu.

72. Les exportateurs camerounais de safou (Dacryodes edulis) sur le marché sous régional et international. Profil, fonctionnement et stratégies de développement.

73. Impact of the Southeast Asian Network for Agroforestry Education (SEANAFE) on agroforestry education capacity.

74. Setting landscape conservation targets and promoting them through compatible land use in the Philippines.

75. Review of methods for researching multistrata systems.

76. Study on economical viability of Jatropha curcas L. plantations in Northern Tanzania assessing farmers' prospects via cost-benefit analysis

77. Cooperation in Agroforestry between Ministry of Forestry of Indonesia and International Center for Research in Agroforestry

78. "China's bioenergy future. an analysis through the Lens if Yunnan Province

79. Land tenure and agricultural productivity in Africa: A comparative analysis of the economics literature and recent policy strategies and reforms

80. Boundary organizations, objects and agents: linking knowledge with action in Agroforestry watersheds

81. Reducing emissions from deforestation and forest degradation (REDD) in Indonesia: options and challenges for fair and efficient payment distribution mechanisms 
82. Mainstreaming climate change into agricultural education: challenges and perspectives

83. Challenging conventional mindsets and disconnects in conservation: the emerging role of ecoagriculture in Kenya's landscape mosaics

84. Lesson learned RATA garut dan bengkunat: suatu upaya membedah kebijakan pelepasan kawasan hutan dan redistribusi tanah bekas kawasan hutan

85. The emergence of forest land redistribution in Indonesia

86. Commercial opportunities for fruit in Malawi

87. Status of fruit production processing and marketing in Malawi

88. Fraud in tree science

89. Trees on farm: analysis of global extent and geographical patterns of agroforestry

90. The springs of Nyando: water, social organization and livelihoods in Western Kenya

91. Building capacity toward region-wide curriculum and teaching materials development in agroforestry education in Southeast Asia

92. Overview of biomass energy technology in rural Yunnan (Chinese - English abstract)

93. A pro-growth pathway for reducing net GHG emissions in China

94. Analysis of local livelihoods from past to present in the central Kalimantan Ex-Mega Rice Project area

95. Constraints and options to enhancing production of high quality feeds in dairy production in Kenya, Uganda and Rwanda

2010

96. Agroforestry education in the Philippines: status report from the Southeast Asian Network for Agroforestry Education (SEANAFE)

97. Economic viability of Jatropha curcas L. plantations in Northern Tanzania- assessing farmers' prospects via cost-benefit analysis.

98. Hot spot of emission and confusion: land tenure insecurity, contested policies and competing claims in the central Kalimantan Ex-Mega Rice Project area

99. Agroforestry competences and human resources needs in the Philippines

100. CES/COS/CIS paradigms for compensation and rewards to enhance environmental Services

101. Case study approach to region-wide curriculum and teaching materials development in agroforestry education in Southeast Asia

102. Stewardship agreement to reduce emissions from deforestation and degradation (REDD): Lubuk Beringin's Hutan Desa as the first village forest in Indonesia

103. Landscape dynamics over time and space from ecological perspective

104. Komoditisasi atau koinvestasi jasa lingkungan: skema imbal jasa lingkungan program peduli sungai di DAS Way Besai, Lampung, Indonesia

105. Improving smallholders' rubber quality in Lubuk Beringin, Bungo district, Jambi province, Indonesia: an initial analysis of the financial and social benefits

106. Rapid Carbon Stock Appraisal (RACSA) in Kalahan, Nueva Vizcaya, Philippines

107. Tree domestication by ICRAF and partners in the Peruvian Amazon: lessons learned and future prospects in the domain of the Amazon Initiative eco-regional program

108. Memorias del Taller Nacional: "Iniciativas para Reducir la Deforestación en la region Andino Amazónica", 09 de Abril del 2010. Proyecto REALU Peru

109. Percepciones sobre la Equidad y Eficiencia en la cadena de valor de REDD en Perú -Reporte de Talleres en Ucayali, San Martín y Loreto, 2009. Proyecto REALU-Perú. 
110. Reducción de emisiones de todos los Usos del Suelo. Reporte del Proyecto REALU Perú Fase 1

111. Programa Alternativas a la Tumba-y-Quema (ASB) en el Perú. Informe Resumen y Síntesis de la Fase II. 2da. versión revisada

112. Estudio de las cadenas de abastecimiento de germoplasma forestal en la amazonía Boliviana

113. Biodiesel in the Amazon

114. Estudio de mercado de semillas forestales en la amazonía Colombiana

115. Estudio de las cadenas de abastecimiento de germoplasma forestal en Ecuador http://dx.doi.org10.5716/WP10340.PDF

116. How can systems thinking, social capital and social network analysis help programs achieve impact at scale?

117. Energy policies, forests and local communities in the Ucayali Region, Peruvian Amazon

118. NTFPs as a Source of Livelihood Diversification for Local Communities in the Batang Toru Orangutan Conservation Program

119. Studi Biodiversitas: Apakah agroforestry mampu mengkonservasi keanekaragaman hayati di DAS Konto?

120. Estimasi Karbon Tersimpan di Lahan-lahan Pertanian di DAS Konto, Jawa Timur

121. Implementasi Kaji Cepat Hidrologi (RHA) di Hulu DAS Brantas, Jawa Timur. http://dx.doi.org/10.5716/WP10338.PDF

122. Kaji Cepat Hidrologi di Daerah Aliran Sungai Krueng Peusangan, NAD,Sumatra http://dx.doi.org/10.5716/WP10337.PDF

123. A Study of Rapid Hydrological Appraisal in the Krueng Peusangan Watershed, NAD, Sumatra. http://dx.doi.org/10.5716/WP10339.PDF

2011

124. An Assessment of farm timber value chains in Mt Kenya area, Kenya

125. A Comparative financial analysis of current land use systems and implications for the adoption of improved agroforestry in the East Usambaras, Tanzania

126. Agricultural monitoring and evaluation systems

127. Challenges and opportunities for collaborative landscape governance in the East Usambara Mountains, Tanzania

128. Transforming Knowledge to Enhance Integrated Natural Resource Management Research, Development and Advocacy in the Highlands of Eastern Africa http://dx.doi.org/10.5716/WP11084.PDF

129. Carbon-forestry projects in the Philippines: potential and challenges The Mt Kitanglad Range forestcarbon development http://dx.doi.org10.5716/WP11054.PDF

130. Carbon forestry projects in the Philippines: potential and challenges. The Arakan Forest Corridor forest-carbon project. http://dx.doi.org10.5716/WP11055.PDF

131. Carbon-forestry projects in the Philippines: potential and challenges. The Laguna Lake Development Authority's forest-carbon development project. http://dx.doi.org/10.5716/WP11056.PDF

132. Carbon-forestry projects in the Philippines: potential and challenges. The Quirino forest-carbon development project in Sierra Madre Biodiversity Corridor http://dx.doi.org10.5716/WP11057.PDF

133. Carbon-forestry projects in the Philippines: potential and challenges. The Ikalahan Ancestral Domain forest-carbon development http://dx.doi.org10.5716/WP11058.PDF

134. The Importance of Local Traditional Institutions in the Management of Natural Resources in the Highlands of Eastern Africa. http://dx.doi.org/10.5716/WP11085.PDF 
135. Socio-economic assessment of irrigation pilot projects in Rwanda. http://dx.doi.org/10.5716/WP11086.PDF

136. Performance of three rambutan varieties (Nephelium lappaceum L.) on various nursery media. http://dx.doi.org/10.5716/WP11232.PDF

137. Climate change adaptation and social protection in agroforestry systems: enhancing adaptive capacity and minimizing risk of drought in Zambia and Honduras http://dx.doi.org/10.5716/WP11269.PDF

138. Does value chain development contribute to rural poverty reduction? Evidence of asset building by smallholder coffee producers in Nicaragua http://dx.doi.org/10.5716/WP11271.PDF

139. Potential for biofuel feedstock in Kenya. http://dx.doi.org/10.5716/WP11272.PDF

140. Impact of fertilizer trees on maize production and food security in six districts of Malawi. http://dx.doi.org/10.5716/WP11281.PDF

\section{2}

141. Fortalecimiento de capacidades para la gestión del Santuario Nacional Pampa Hermosa:

Construyendo las bases para un manejo adaptativo para el desarrollo local. Memorias del Proyecto. http://dx.doi.org/10.5716/WP12005.PDF

142. Understanding rural institutional strengthening: A cross-level policy and institutional framework for sustainable development in Kenya http://dx.doi.org/10.5716/WP12012.PDF

143. Climate change vulnerability of agroforestry http://dx.doi.org/10.5716/WP16722.PDF

144. Rapid assesment of the inner Niger delta of Mali http://dx.doi.org/10.5716/WP12021.PDF

145. Designing an incentive program to reduce on-farm deforestationin the East Usambara Mountains, Tanzania http://dx.doi.org/10.5716/WP12048.PDF

146. Extent of adoption of conservation agriculture and agroforestry in Africa: the case of Tanzania, Kenya, Ghana, and Zambia http://dx.doi.org/10.5716/WP12049.PDF

147. Policy incentives for scaling up conservation agriculture with trees in Africa: the case of Tanzania, Kenya, Ghana and Zambia http://dx.doi.org/10.5716/WP12050.PDF

148. Commoditized or co-invested environmental services? Rewards for environmental services scheme: River Care program Way Besai watershed, Lampung, Indonesia. http://dx.doi.org/10.5716/WP12051.PDF

149. Assessment of the headwaters of the Blue Nile in Ethiopia. http://dx.doi.org/10.5716/WP12160.PDF

150. Assessment of the uThukela Watershed, Kwazaulu. http://dx.doi.org/10.5716/WP12161.PDF

151. Assessment of the Oum Zessar Watershed of Tunisia. http://dx.doi.org/10.5716/WP12162.PDF

152. Assessment of the Ruwenzori Mountains in Uganda. http://dx.doi.org/10.5716/WP12163.PDF

153. History of agroforestry research and development in Viet Nam. Analysis of research opportunities and gaps. http://dx.doi.org/10.5716/WP12052.PDF

154. REDD+ in Indonesia: a Historical Perspective. http://dx.doi.org/10.5716/WP12053.PDF

155. Agroforestry and Forestry in Sulawesi series: Livelihood strategies and land use system dynamics in South Sulawesi http://dx.doi.org/10.5716/WP12054.PDF

156. Agroforestry and Forestry in Sulawesi series: Livelihood strategies and land use system dynamics in Southeast Sulawesi. http://dx.doi.org/10.5716/WP12055.PDF

157. Agroforestry and Forestry in Sulawesi series: Profitability and land-use systems in South and Southeast Sulawesi. http://dx.doi.org/10.5716/WP12056.PDF

158. Agroforestry and Forestry in Sulawesi series: Gender, livelihoods and land in South and Southeast Sulawesi http://dx.doi.org/10.5716/WP12057.PDF 
159. Agroforestry and Forestry in Sulawesi series: Agroforestry extension needs at the community level in AgFor project sites in South and Southeast Sulawesi, Indonesia. http://dx.doi.org/10.5716/WP12058.PDF

160. Agroforestry and Forestry in Sulawesi series: Rapid market appraisal of agricultural, plantation and forestry commodities in South and Southeast Sulawesi. http://dx.doi.org/10.5716/WP12059.PDF

\section{3}

161. Diagnosis of farming systems in the Agroforestry for Livelihoods of Smallholder farmers in Northwestern Viet Nam project http://dx.doi.org/10.5716/WP13033.PDF

162. Ecosystem vulnerability to climate change: a literature review. http://dx.doi.org/10.5716/WP13034.PDF

163. Local capacity for implementing payments for environmental services schemes: lessons from the RUPES project in northeastern Viet Nam http://dx.doi.org/10.5716/WP13046.PDF

164. Seri Agroforestri dan Kehutanan di Sulawesi: Agroforestry dan Kehutanan di Sulawesi: Strategi mata pencaharian dan dinamika sistem penggunaan lahan di Sulawesi Selatan http://dx.doi.org/10.5716/WP13040.PDF

165. Seri Agroforestri dan Kehutanan di Sulawesi: Mata pencaharian dan dinamika sistem penggunaan lahan di Sulawesi Tenggara http://dx.doi.org/10.5716/WP13041.PDF

166. Seri Agroforestri dan Kehutanan di Sulawesi: Profitabilitas sistem penggunaan lahan di Sulawesi Selatan dan Sulawesi Tenggara http://dx.doi.org/10.5716/WP13042.PDF

167. Seri Agroforestri dan Kehutanan di Sulawesi: Gender, mata pencarian dan lahan di Sulawesi Selatan dan Sulawesi Tenggara http://dx.doi.org/10.5716/WP13043.PDF

168. Seri Agroforestri dan Kehutanan di Sulawesi: Kebutuhan penyuluhan agroforestri pada tingkat masyarakat di lokasi proyek AgFor di Sulawesi Selatan dan Tenggara, Indonesia. http://dx.doi.org/10.5716/WP13044.PDF

169. Seri Agroforestri dan Kehutanan di Sulawesi: Laporan hasil penilaian cepat untuk komoditas pertanian, perkebunan dan kehutanan di Sulawesi Selatan dan Tenggara http://dx.doi.org/10.5716/WP13045.PDF

170. Agroforestry, food and nutritional security http://dx.doi.org/10.5716/WP13054.PDF

171. Stakeholder Preferences over Rewards for Ecosystem Services: Implications for a REDD+ Benefit Distribution System in Viet Nam http://dx.doi.org/10.5716/WP13057.PDF

172. Payments for ecosystem services schemes: project-level insights on benefits for ecosystems and the rural poor http://dx.doi.org/10.5716/WP13001.PDF

173. Good practices for smallholder teak plantations: keys to success http://dx.doi.org/10.5716/WP13246.PDF

174. Market analysis of selected agroforestry products in the Vision for Change Project intervention Zone, Côte d'Ivoire http://dx.doi.org/10.5716/WP13249.PDF

175. Rattan futures in Katingan: why do smallholders abandon or keep their gardens in Indonesia's 'rattan district'? http://dx.doi.org/10.5716/WP13251.PDF

176. Management along a gradient: the case of Southeast Sulawesi's cacao production landscapes http://dx.doi.org/10.5716/WP13265.PDF 
177. Are trees buffering ecosystems and livelihoods in agricultural landscapes of the Lower Mekong Basin? Consequences for climate-change adaptation. http://dx.doi.org/10.5716/WP14047.PDF

178. Agroforestry, livestock, fodder production and climate change adaptation and mitigation in East Africa: issues and options. http://dx.doi.org/10.5716/WP14050.PDF

179. Trees on farms: an update and reanalysis of agroforestry's global extent and socio-ecological characteristics. http://dx.doi.org/10.5716/WP14064.PDF

180. Beyond reforestation: an assessment of Vietnam's REDD+ readiness. http://dx.doi.org/10.5716/WP14097.PDF

181. Farmer-to-farmer extension in Kenya: the perspectives of organizations using the approach. http://dx.doi.org/10.5716/WP14380.PDF

182. Farmer-to-farmer extension in Cameroon: a survey of extension organizations. http://dx.doi.org/10.5716/WP14383.PDF

183. Farmer-to-farmer extension approach in Malawi: a survey of organizations: a survey of organizations http://dx.doi.org/10.5716/WP14391.PDF

184. Seri Agroforestri dan Kehutanan di Sulawesi: Kuantifikasi jasa lingkungan air dan karbon pola agroforestri pada hutan rakyat di wilayah sungai Jeneberang

185. Options for Climate-Smart Agriculture at Kaptumo Site in Kenyahttp://dx.doi.org/10.5716/WP14394.PDF

\section{5}

186. Agroforestry for Landscape Restoration and Livelihood Development in Central Asia http://dx.doi.org/10.5716/WP14143.PDF

187. "Projected Climate Change and Impact on Bioclimatic Conditions in the Central and South-Central Asia Region" http://dx.doi.org/10.5716/WP14144.PDF

188. Land Cover Changes, Forest Loss and Degradation in Kutai Barat, Indonesia. http://dx.doi.org/10.5716/WP14145.PDF

189. The Farmer-to-Farmer Extension Approach in Malawi: A Survey of Lead Farmers. http://dx.doi.org/10.5716/WP14152.PDF

190. Evaluating indicators of land degradation and targeting agroforestry interventions in smallholder farming systems in Ethiopia. http://dx.doi.org/10.5716/WP14252.PDF

191. Land health surveillance for identifying land constraints and targeting land management options in smallholder farming systems in Western Cameroon

192. Land health surveillance in four agroecologies in Malawi

193. Cocoa Land Health Surveillance: an evidence-based approach to sustainable management of cocoa landscapes in the Nawa region, South-West Côte d'Ivoire http://dx.doi.org/10.5716/WP14255.PDF

194. Situational analysis report: Xishuangbanna autonomous Dai Prefecture, Yunnan Province, China. http://dx.doi.org/10.5716/WP14255.PDF

195. Farmer-to-farmer extension: a survey of lead farmers in Cameroon. http://dx.doi.org/10.5716/WP15009.PDF

196. From transition fuel to viable energy source Improving sustainability in the sub-Saharan charcoal sector http://dx.doi.org/10.5716/WP15011.PDF

197. Mobilizing Hybrid Knowledge for More Effective Water Governance in the Asian Highlands http://dx.doi.org/10.5716/WP15012.PDF

198. Water Governance in the Asian Highlands http://dx.doi.org/10.5716/WP15013.PDF

199. Assessing the Effectiveness of the Volunteer Farmer Trainer Approach in Dissemination of Livestock Feed Technologies in Kenya vis-à-vis other Information Sources

http://dx.doi.org/10.5716/WP15022.PDF 
200. The rooted pedon in a dynamic multifunctional landscape: Soil science at the World Agroforestry Centre http://dx.doi.org/10.5716/WP15023.PDF

201. Characterising agro-ecological zones with local knowledge. Case study: Huong Khe district, Ha Tinh, Viet Nam http://dx.doi.org/10.5716/WP15050.PDF

202. Looking back to look ahead: Insight into the effectiveness and efficiency of selected advisory approaches in the dissemination of agricultural technologies indicative of Conservation Agriculture with Trees in Machakos County, Kenya. http://dx.doi.org/10.5716/WP15065.PDF

203. Pro-poor Biocarbon Projects in Eastern Africa Economic and Institutional Lessons. http://dx.doi.org/10.5716/WP15022.PDF

204. Projected climate change impacts on climatic suitability and geographical distribution of banana and coffee plantations in Nepal. http://dx.doi.org/10.5716/WP15294.PDF

205. Agroforestry and Forestry in Sulawesi series: Smallholders' coffee production and marketing in Indonesia. A case study of two villages in South Sulawesi Province. http://dx.doi.org/10.5716/WP15690.PDF

206. Mobile phone ownership and use of short message service by farmer trainers: a case study of Olkalou and Kaptumo in Kenya http://dx.doi.org/10.5716/WP15691.PDF

207. Associating multivariate climatic descriptors with cereal yields: a case study of Southern Burkina Faso http://dx.doi.org/10.5716/WP15273.PDF

208. Preferences and adoption of livestock feed practices among farmers in dairy management groups in Kenya http://dx.doi.org/10.5716/WP15675.PDF

209. Scaling up climate-smart agriculture: lessons learned from South Asia and pathways for success http://dx.doi.org/10.5716/WP15720.PDF

210. Agroforestry and Forestry in Sulawesi series: Local perceptions of forest ecosystem services and collaborative formulation of reward mechanisms in South and Southeast Sulawesi http://dx.doi.org/10.5716/WP15721.PDF

211. Potential and challenges in implementing the co-investment of ecosystem services scheme in Buol District, Indonesia. http://dx.doi.org/10.5716/WP15722.PDF

212. Tree diversity and its utilization by the local community in Buol District, Indonesia http://dx.doi.org/10.5716/WP15723.PDF

213 Vulnerability of smallholder farmers and their preferences on farming practices in Buol District, Indonesia http://dx.doi.org/10.5716/WP15724.PDF

214. Dynamics of Land Use/Cover Change and Carbon Emission in Buol District, Indonesia http://dx.doi.org/10.5716/WP15725.PDF

215. Gender perspective in smallholder farming practices in Lantapan, Phillippines. http://dx.doi.org/10.5716/WP15726.PDF

216. Vulnerability of smallholder farmers in Lantapan, Bukidnon. http://dx.doi.org/10.5716/WP15727.PDF

217. Vulnerability and adaptive capacity of smallholders in Ho Ho sub-watershed, north-central Viet Nam http://dx.doi.org/10.5716/WP15728.PDF

218. Local knowledge on the role of trees to enhance livelihoods and ecosystem services in Ho Ho Subwatershed, north-central Viet Nam http://dx.doi.org/10.5716/WP15729.PDF

219. Landuse/cover change in Ho Ho Sub-watershed, north-central Viet Nam. http://dx.doi.org/10.5716/WP15730.PDF 
220. Agroforestry and Forestry in Sulawesi series: Evaluation of the Agroforestry Farmer Field Schools on agroforestry management in South and Southeast Sulawesi, Indonesia.

http://dx.doi.org/10.5716/WP16002.PDF

221 Farmer-to-farmer extension of livestock feed technologies in Rwanda: A survey of volunteer farmer trainers and organizations. http://dx.doi.org/10.5716/WP16005.PDF

222 Projected Climate Change Impact on Hydrology, Bioclimatic Conditions, and Terrestrial Ecosystems in the Asian Highlands http://dx.doi.org/10.5716/WP16006.PDF

223 Adoption of Agroforestry and its impact on household food security among farmers in Malawi http://dx.doi.org/10.5716/WP16013.PDF

224 Agroforestry and Forestry in Sulawesi series: Information channels for disseminating innovative agroforestry practices to villages in Southern Sulawesi, Indonesia http://dx.doi.org/10.5716/WP16034.PDF

225 Agroforestry and Forestry in Sulawesi series: Unravelling rural migration networks.Land-tenure arrangements among Bugis migrant communities in Southeast Sulawesi. http://dx.doi.org/10.5716/WP16035.PDF

226 Agroforestry and Forestry in Sulawesi series: Women's participation in agroforestry: more benefit or burden? A gendered analysis of Gorontalo Province. http://dx.doi.org/10.5716/WP16036.PDF

227 Kajian Kelayakan dan Pengembangan Desain Teknis Rehabilitasi Pesisir di Sulawesi Tengah. http://dx.doi.org/10.5716/WP16037.PDF

228. Selection of son tra clones in North West Vietnam. http://dx.doi.org/10.5716/WP16038.PDF

229. Growth and fruit yield of seedlings, cuttings and grafts from selected son tra trees in Northwest Vietnam http://dx.doi.org/10.5716/WP16046.PDF

230. Gender-Focused Analysis of Poverty and Vulnerability in Yunnan, China. http://dx.doi.org/10.5716/WP16071.PDF

231. Kebutuhan Penyuluhan Agroforestri untuk Rehabilitasi Lahan di Sumba Timur, Nusa Tenggara Timur, Indonesia.http://dx.doi.org/10.5716/WP16077.PDF

232. Agroforestry extension needs for land rehabilitation in East Sumba, East Nusa Tenggara, Indonesia. http://dx.doi.org/10.5716/WP16078.PDF

233. Central hypotheses for the third agroforestry paradigm within a common definition. http://dx.doi.org/10.5716/WP16079.PDF 

The World Agroforestry Centre is an autonomous, non-profit research organization whose vision is a rural transformation in the developing world as smallholder households increase their use of trees in agricultural landscapes to improve food security, nutrition, income, health, shelter, social cohesion, energy resources and environmental sustainability. The Centre generates science-based knowledge about the diverse roles that trees play in agricultural landscapes, and uses its research to advance policies and practices, and their implementation that benefit the poor and the environment. It aims to ensure that all this is achieved by enhancing the quality of its science work, increasing operational efficiency, building and maintaining strong partnerships, accelerating the use and impact of its research, and promoting greater cohesion, interdependence and alignment within the organization.

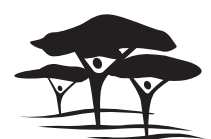

United Nations Avenue, Gigiri • PO Box 30677 • Nairobi, $00100 \cdot$ Kenya Telephone: +254 207224000 or via USA +1 6508336645 Fax: +254207224001 or via USA +1 6508336646

Email: worldagroforestry@cgiar.org•www.worldagroforestry.org

Southeast Asia Regional Program • Sindang Barang • Bogor 16680

PO Box $161 \cdot$ Bogor $16001 \cdot$ Indonesia

Telephone: +62 2518625415 • Fax: +62 2518625416

- Email: icraf-indonesia@cgiar.org

www.worldagroforestry.org/regions/southeast_asia

blog.worldagroforestry.org 